\title{
Woodland Owners Motivations for Involvement in Landscape Scale Forest Stewardship
}

Ana Maria Erazo

West Virginia University

Follow this and additional works at: https://researchrepository.wvu.edu/etd

\section{Recommended Citation}

Erazo, Ana Maria, "Woodland Owners Motivations for Involvement in Landscape Scale Forest Stewardship" (2014). Graduate Theses, Dissertations, and Problem Reports. 618.

https://researchrepository.wvu.edu/etd/618

This Thesis is protected by copyright and/or related rights. It has been brought to you by the The Research Repository @ WVU with permission from the rights-holder(s). You are free to use this Thesis in any way that is permitted by the copyright and related rights legislation that applies to your use. For other uses you must obtain permission from the rights-holder(s) directly, unless additional rights are indicated by a Creative Commons license in the record and/ or on the work itself. This Thesis has been accepted for inclusion in WVU Graduate Theses, Dissertations, and Problem Reports collection by an authorized administrator of The Research Repository @ WVU. For more information, please contact researchrepository@mail.wvu.edu. 


\title{
Woodland Owners Motivations for Involvement in Landscape Scale Forest Stewardship
}

by

Ana Maria Erazo

\begin{abstract}
A thesis submitted to the Faculty of Graduate Studies, Davis College of Agriculture and Natural Resources

West Virginia University, WV

in partial fulfillment of the requirements for the degree of
\end{abstract}

Master of Science in Forestry

David McGill, Ph.D.; Chair

Steve Selin, Ph.D.

Sheldon Owen, Ph.D.

Division of Forestry and Natural Resources

Morgantown, West Virginia, WV

August 2014

Key words: Private Forest owners, motivations, cross- boundary cooperation, barriers 


\title{
ABSTRACT \\ Woodland Owners Motivations for Involvement in Landscape Scale Forest Stewardship
}

\begin{abstract}
Ana Maria Erazo
West Virginia is mainly covered by forest, most of which is in the hands of private forest (PF) owners. The decisions taken about the management of these properties affect the landscape beyond their parcel boundaries. These forests provide ecological services to society, timber products and recreation. Keeping the forest healthy and productive is very important for the common good. Threats related to development parcelization, invasive species and pests are some of the challenges when trying to maintain forest coverage in WV. To be able to face these challenges it is necessary to plan at a wider scale than the individual parcel. Landscape scale forest stewardship has been thought of as a way to manage the forest in a multiple tenure scenario. Cross boundary collaboration and public - private partnerships are necessary to move in the direction of large scale forest management. Understanding the attitudes, actions and motivations of PF owners is critical to success in this task.

In this study we conducted a public opinion survey in five diverse areas of West Virginia located along the primary inter-state transportation corridors. This research was designed using similar methodology to a study by Finley et al. (2006), to identify the attitudes, motivations and barriers to cross-boundary cooperation of private forest owners in the selected areas. We conducted a survey that gave 293 usable responses. Using Principal Component Analysis and Logistic Regression, four significant predictors for willingness to participate in cooperative activities were obtained: 1) education, 2) management activities conducted in woodland properties, 3) sharing property, and 4) the barrier "no cooperation benefits." Also, two dependent variables "market jointly" and "walking tour" to measure the interest of PF owners in engaging with neighbors in education and planning were obtained. Findings suggest that those with a college degree or higher had more than twice the odds of being willing to participate in cooperative activities, those interested in "share" had five times the odds of being interested in cooperative activities than those than were not. Private forest owners doing management activities on their properties were more inclined to participate in cooperative activities. The barrier "no cooperation benefits" produced odds ratio less than one for both cooperative activity variables suggesting those with an unfavorable view of cross-boundary benefits are less willing to collaborate with neighbors.
\end{abstract}




\section{ACKNOWLEDGEMENTS}

First of all I would like to thank my advisor Dr. Dave McGill for his patience, constant support and guidance throughout my research and studies. Also I would like to thank my committee members: Dr.

Sheldon Owen and Dr. Steve Selin for their contributions to my research. I would like to thank my dear friend William Bryan who has been always there for me with his wise support. Finally I would like to thank my family for their love. 


\section{TABLE OF CONTENTS}

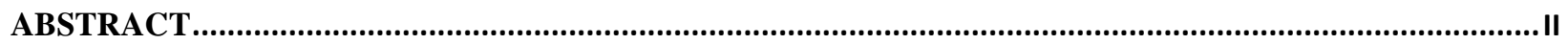

ACKNOWLEDGEMENTS...............................................................................................................................

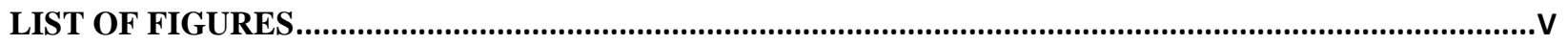

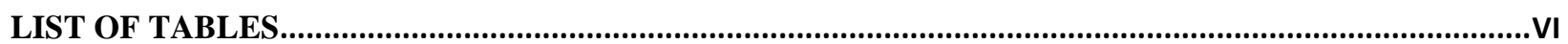

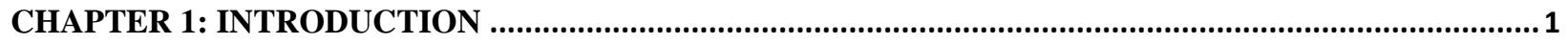

CHAPTER 2: LITERATURE REVIEW ….................................................................................................

IMPORTANCE OF NON INDUSTRIAL PRIVATE FOREST OWNERS AND ACTIONS TAKEN .........................................

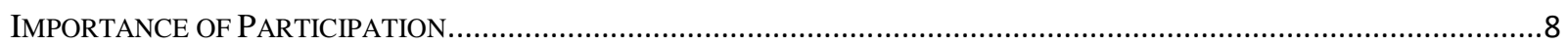

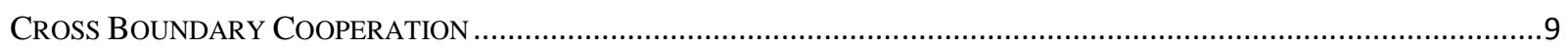

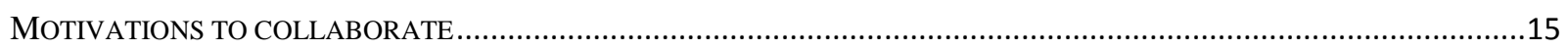

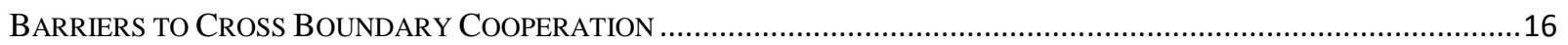

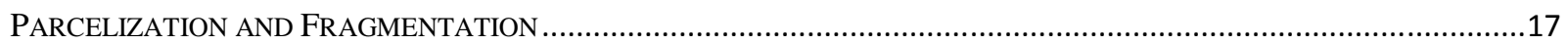

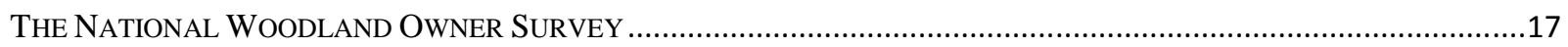

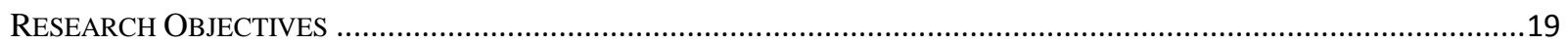

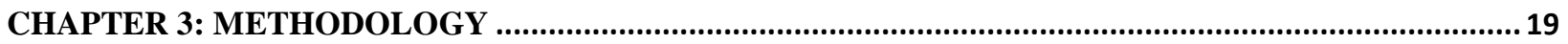

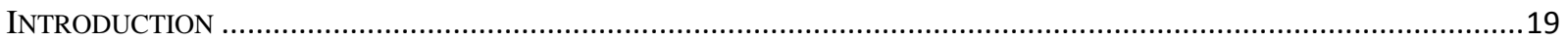

PHASE ONE .

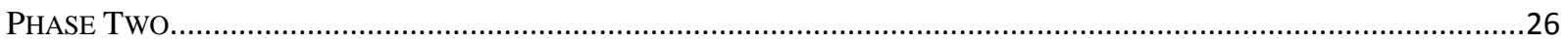

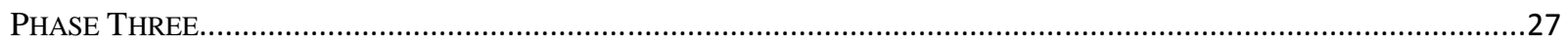

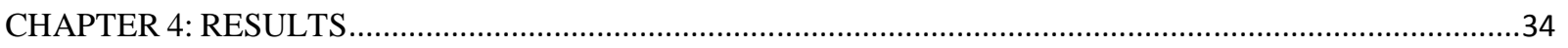

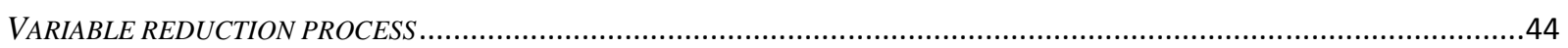

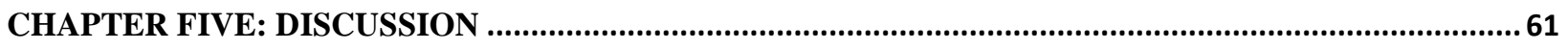

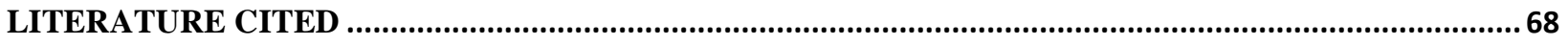

APPENDIX A. INITIAL CONTACT COVER LETTER ............................................................................. 76

APPENDIX B. INFORMATIONAL PACKAGE: COVER LETTER AND OTHER INFORMATION.......... 77

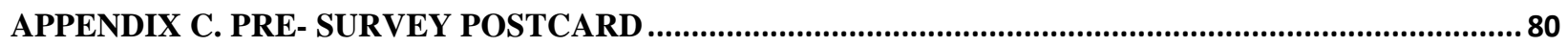

APPENDIX D. QUESTIONNAIRE/ MASTER KEY …................................................................................ 81

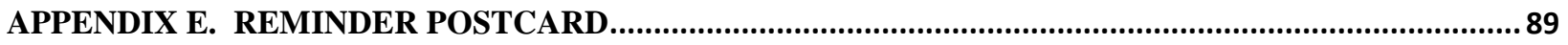

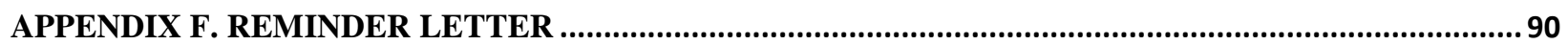

APPENDIX G. LIST OF CONSERVATION ORGANIZATIONS IDENTIFIED BY POSTCARD

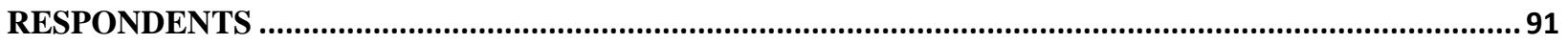




\section{LIST OF FIGURES}

Figure 1: Public private forest. Map source :NRS-INF, 2008..........................4

Figure 2. WV Forestland distribution . Map source: Widman et al. (2008) ("based on the Multi-

Resolution Land Characteristics project, NLCD2006")...............................6

Figure 3: Map of WV counties within the five geographic areas of study....................21

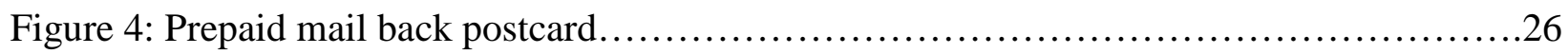

Figure 5: Postcard responses related to conservation easement and cooperation.................35

Figure 6: Public and private organization identified by postcard respondents..................36

Figure 7: Number of organizations identified by postcard respondents/county $\ldots \ldots \ldots \ldots \ldots \ldots . \ldots 36$

Figure 8: Themes used to group "landscape" descriptions and percent of responses..............39

Figure 9: Percentage of responses by theme. Used to group "desirable features"..............40

Figure 10: Percentage of responses by theme used to group "natural resource to protect"........40

Figure 11: Themes and percent of responses for "main threats" to forestland.................41

Figure 12(a-b): Themes and percent of responses for "main threats" to forestland by county....42

Figure 13: Percent responses for top reasons to own by descriptor type....................43

Figure 14: Percentage of PF Owners According to their Reasons to Participating in Natural Resources Organizations......................................................44

Figure 15: Parallel analysis with Eigen values generated from reasons to own data compared with 95th percentile Eigen values from simulated random populations......................46

Figure 16: Parallel analysis with Eigen values generated from cross-boundary data compared with 95th percentile Eigen values from simulated random populations

Figure 17: Parallel analysis with Eigen values generated from barriers to collaboration data compared with 95th percentile Eigen values from simulated random populations.... 


\section{LIST OF TABLES}

Table 1: Demographics related to population, education, and income......................22

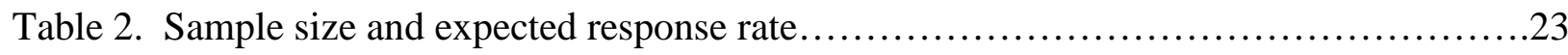

Table 3. Open ended questions to assess perceptions and attitudes of WO regarding ownership,

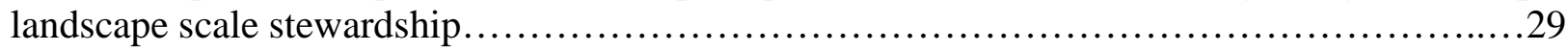

Table 4. Main threats to forestland ................................................. 41

Table 5. Top Reasons to own descriptions by theme .................................43

Table 6. Eigen values and amount of variation in reasons to own forest explained by 9 variables

Table 7. Factor structure for PCA with Varimax rotation related to reasons to own. Bold loading of variables on factors indicate most significant for given variable..................46

Table 8. Survey items related to reasons for owning property and descriptive statistics for principal components analysis

Table 9. Eigen values and amount of variation explained in cross-boundary attitudes by 18 variables

Table 10. Factor structure for PCA with Varimax rotation. Bold loading of variables on factors indicate most significant for given variable.

Table 11. Survey items assessing attitudes and actions associated with cross-boundary cooperation and descriptive statistics for principal components analysis.

Table 12. Eigen values and amount of variation explained in barriers to collaboration by eight variables.

Table 13. Factor structure for PCA with Varimax rotation. Bold loading of variables on factors indicate most significant for given variable.

Table 14: Survey items assessing barriers to cross-boundary cooperation and descriptive statistics for principal components analysis.

Table 15. Survey items of suggested Cooperative Activities and descriptive statistics for principal components analysis.

Table 16. Description of PC variables and others to use in logistic model ..................56

Table 17. Results from logistic regression for CAmgt and independent PC variables...........57

Table 18. Results from logistic regression for CAdev and independent PC variables............57 
Table 19. Results from logistic regression for CAmgt and other independent variables.........58

Table 20. Results from logistic regression for Cadev and other independent variables..........59

Table 21. Variables to measure willingness to participate in CA.........................59 


\section{CHAPTER 1: INTRODUCTION}

Seventy-eight percent of West Virginia's territory is covered by forest (12 million acres) and 98\% of it is classified as timberland (Widmann et al., 2012; USDA Forest Service). Only 13\% of forest land in WV is publicly owned, the equivalent is approximately 1.5 million acres. The majority of forest is owned by private individuals ( 7.2 million acres) consisting of family forest owners and enterprises (3.2 million acres) (Widmann et al., 2012; USDA Forest Service)

A major threat to West Virginia's forest is residential and business development which contributes to fragmentation and parcelization. Considering that $71 \%$ of WV private landowners are over the age of 55, trans-generational land transfer is imminent (Widmann et al., 2012; USDA Forest Service). In addition, Real Estate Investment Trusts are one of the fastest growing ownership categories in West Virginia, and many private industrial forest owners have sold their lands to these types of investment organizations (WVDOF, 2010). Forest management gets more complicated when the landscape is made up of several small parcels and this has been linked to forest fragmentation (Holdt et al., 2004). Repeated change of ownership becomes an issue when trying to reach PF owners.

While the provision of timber and ecosystem services lays mainly in the hands of private forest owners, however very few (3\%) have management plan (Butler \& Leatherby, 2004). The involvement of private owners in forest management activities is a key issue among natural resources management professionals and is thought to be crucial to maintaining healthy forests and ecosystem services. Cross-boundary cooperation offers the opportunity of expanding the provision of ecosystems (Rickenbach et al., 2011). 
Most private forest owners do not own their land for monetary gain but for privacy, enjoyment, or family reasons (Butler \& Leatherby, 2004; Belin, 2005). Studies conducted to evaluate the interest and motivations of private forest owners in forest management based on attitudes and level of engagement led to the identification of particular types (segments) of PF owners with common interests (Finley et al., 2006; Butler et al., 2007). Bringing private forest owners into cooperative initiatives to manage their woodlands will increase the possibility of economies of scale where more units are produced with less input cost (Heakal, 2014), providing more opportunities for them to access information and communicate while maintaining healthy forests. Barriers to cooperation include resistance to change, lack of knowledge, lack of understanding of what is required from the participants in the process and lack of resources (Jacobson, Abt \& Carter, 2000; Leong et al., 2011).

Fragmentation has been identified as an impact from gas development and other energy related industries in Pennsylvania. Infrastructure required for gas development, such as landings for heavy equipment, roads, processing plants, right of way (ROW) etc. are some of the concerns (PA DCNR, 2010). In 2009 a new policy to issue ROW permits in state forests and parklands was developed by the PA Department of Conservation and Natural Resources because of the escalating number requested since 2008. Right of way had been related to spread of invasive species and a great number of permits were requested for new gas pipelines in Pennsylvania (PA DCNR, 2010). Increased communication between natural resources agencies, industry and the public, the use of public forums to mediate conflicts and cross-boundary cooperation are possible approaches to minimizing impact of development on the ecosystem.

Development, parcelization, invasive species, mining, gas, oil operations and fire are some of the threats to forest identified by respondents and agencies in this study, and the way to address each 
issue will vary in each case, for instance development might involve long term agreements such as conservation easement, requiring a longer period of time than in the case of wildfire suppression which requires an immediate action.

Designed after a study by Finley et al. (2006) the purpose of this research is to identify the attitudes, motivations and barriers to cross-boundary cooperation of among private forest owners in five geographic areas of the state of West Virginia. This constitutes an initial step toward landscape scale forest stewardship (LSFS) planning initiatives to promote sustainable forest management on private and public lands in WV. The discussion revolves around the identification of those PF owners willing to get involved in cooperative activities across boundaries.

Through the review of literature, and by using empirical observations and data collected from postcards and questionnaires the research question was to find out the ways private forest (PF) owners interact, their perceptions of cross-boundary cooperation, and their motivations for involvement in it. Results of this study will be used to tailor the way natural resource managers engage PF owners and recruit them into LSFS initiatives. We will also use our results to guide future research.

\section{CHAPTER 2: LITERATURE REVIEW}

There are 751 million acres of forest land in the USA and 56\% (423 million acres) is in the hands of 11 million private owners, of which 10 million are considered family forest owners. The latter are defined as families, trusts, individuals, and other unincorporated forest owners (Butler, 2008). Also known as a subset of "non-industrial private forest owners" (NIPF), this group of 
private landowners possesses $251.9^{1}$ million acres of forestland (USDA, 2008). Private forests in the US produce close to $30 \%$ of the domestic drinking water and $90 \%$ of the domestically produced forest products (USDA, 2011). Nine out of ten private owners have their properties in the eastern USA. Forty-six percent are located in the North, $42 \%$ in the South and only $12 \%$ are spread throughout the West (Butler \& Leatherby, 2004) (see Figure 1).

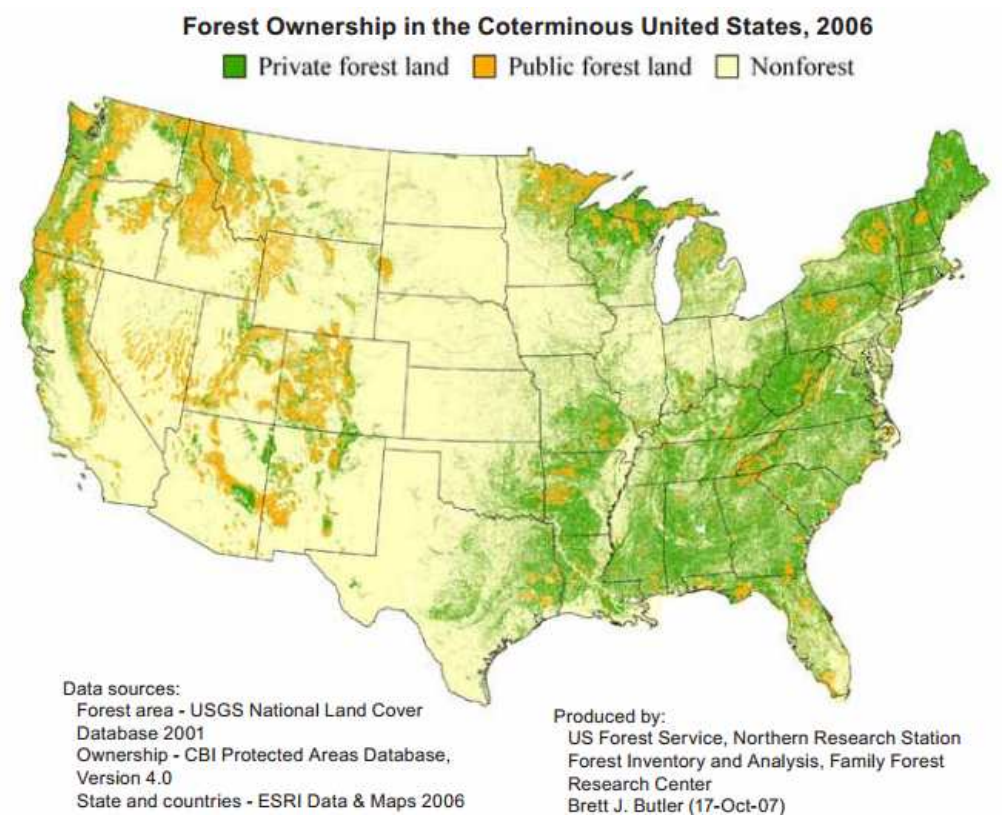

Figure 1: Public private forest. Map source :USDA, NRS-INF, 2008

Involving private forest owners in cross-boundary cooperation is a first step toward forest management on a landscape scale to conserve ecosystems and working forests. When thinking of forest management on a landscape scale, several considerations related to parcelization, fragmentation, public collaboration, willingness of PF owners to collaborate across boundaries and barriers arise. Understanding who these owners are, is important to agencies (local, state, federal) and organizations working in Natural Resources. By recognizing the needs and motivations related to forest ownership, agencies and organizations can make sure that the right

\footnotetext{
${ }^{1}$ Excluding interior Alaska, Hawaii, Nevada, western Oklahoma, and western Texas (Butler 2008).
} 
policies to promote healthy forests and ecosystems are in place.

There are certain characteristics that set PF owners apart; they tend to be older and more educated than the average American (Butler \& Leatherby, 2004). The average age of woodland owners is 60 years, while the average age of Americans 25 years or older is 49. Sixty-two percent of woodland owners attended college in comparison with $50 \%$ of the general population (Butler \& Leatherby, 2004). About 73\% percent of family forest owners have their primary residence on or within one mile of their forestland (Butler, 2008). Information from the National Woodland Owner Survey (NWOS) has been used to classify private woodland owners into segments or categories according to their attitudes, level of engagement, and interest in forest management. Knowing who woodland owners are is important because it allows us to design more effective ways to approach each segment to increase their participation in conservation programs, cross-boundary collaboration or other natural resources initiatives. As the size of private forest landholdings increases, the number of owners decreases. In 2006, 9.78 million PF owners in the US had parcel equal to or less than 49 acres, holding about 22\% (81.7 million acres) of private forest, while 1.3 million PF owners with parcel equal to or greater than 50 acres held the remaining $78 \%$ (247 million acres) (Butler, 2008).

West Virginia is the third most heavily forested state in the nation (Figure 2), with $78 \%$ (12,024,012 acres) of its 15,415,400 acres of land covered by forests (WVDOF, 2010). Ninetyeight percent of these forestlands are categorized as commercial. In West Virginia 10,418,000 $(87 \%)$ acres are private forests, and of those 7,174,000 acres (69\%) are in the hands of 243 thousand family owners (Butler, 2008). 
Considering that the majority of WV forestland is in the hands of private landowners, that public forests are inserted within these private forests, and that the public is entitled to have a say in the management of the latter, it is imperative to consider Landscape Scale Forest Stewardship as a way of managing West Virginia’s forests across ownership boundaries.

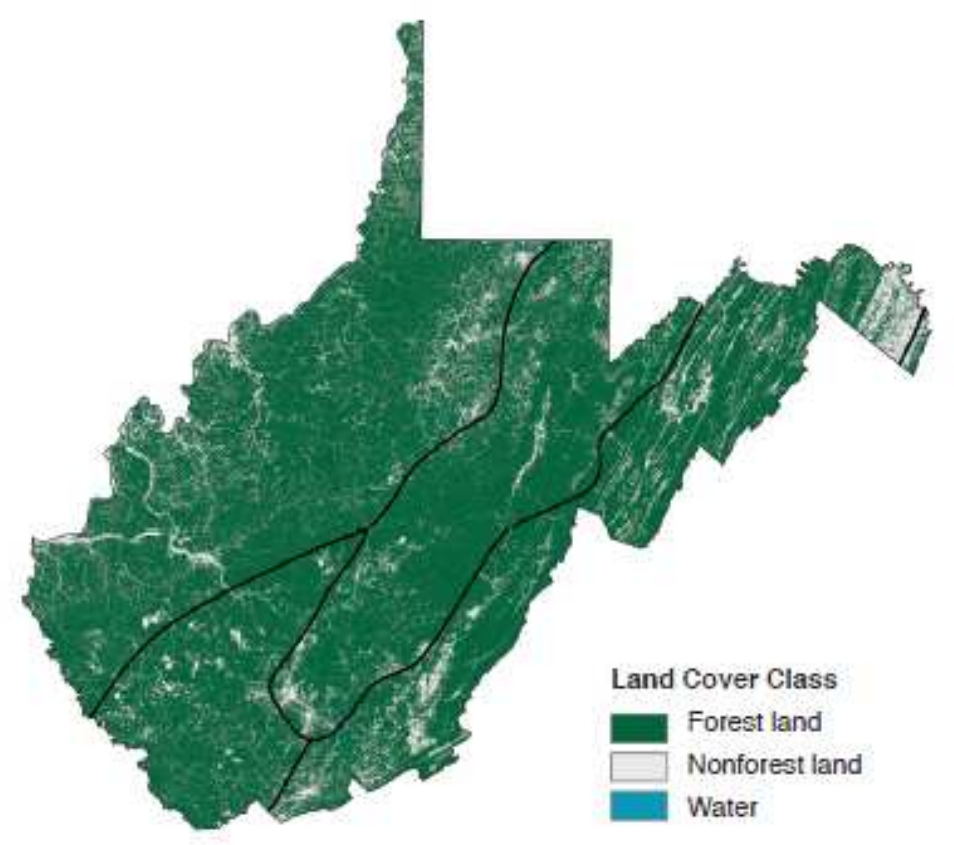

Figure 2. WV Forestland distribution. Map source: Widman et al. (2008) ("based on the MultiResolution Land Characteristics project, NLCD-2006")

\section{Importance of Non Industrial Private Forest Owners and Actions Taken}

The Cooperative Forestry Assistance Act of 1978, in its purpose and policies (Section 2), recognizes the dependence of the United States on nonfederal forestland to maintain renewable forest resources. The Act points out that over half of the timber produced in the nation comes from private non industrial lands and enumerates challenges and threats these private owners face. This law took nine cooperative assistance programs, consolidated some and expanded others. Priorities under the Act include fire protection, reforestation, stand improvement, 
enhancing public benefits, and the management of working forest landscapes (USDA, 2011). Recognizing the worth of private forests, and to better address issues these forests and their owners face, several amendments have been made to the Cooperative Forestry Assistance Act of 1978 through the years.

The Farm Bill of 1990 was the first to include a forestry title and to create programs such as the Forest Stewardship Program, the Forest Legacy Program, and the Economic Action Program to cover private forest issues such as fragmentation and development. The Farm Bill of 2008 amended the Conservation, Forestry, and Energy Titles, establishing the following as national priorities for private forestlands: 1) conservation of working forests landscapes, 2) protection of forests from threats, and 3) enhancement of public benefits from forests (USDA Report to Congress 2011). It also established that State officials shall develop “(1) a State-wide assessment of forest resource conditions, (2) a long-term State-wide forest resource strategy and, (3) an annual report on use of funds." (2008, Food, Conservation, and Energy Act). From 2008 to 2011 technical assistance, mostly in the form of management plans, has been provided to 789,500 forest owners. Investments to address Farm Bill priorities during this period included \$189 million from USDA programs along with at least \$93 million from non-federal funds for forestry and conservation enhancement on more than 4 million acres of land (USDA, 2011).

The Cooperative Forestry Assistance Act, and the Healthy Forests Restoration Act of 2003 are amended by the Farm Bill of 2014 enacted in February 2014. This Bill reauthorizes, rescinds, and modifies current programs under those authorities (Hoover, 2014). Provisions related to nonindustrial private forestlands in the 2014 Farm Bill include the reauthorization until FY2018 of the Conservation Stewardship and the Environmental Quality Incentives Programs. In the Conservation Stewardship Program, the $10 \%$ total acreage enrollment cap for NIPF was removed 
and, the definition of "eligible land" was amended to "nonindustrial private forest land" rather than "agroforestry". The EQUIP Program provides assistance to promote conservation, allowing NIPF to benefit from it.

Currently the mission of the USDA Forest Service is "to sustain the health, diversity, and productivity of the Nation's forests and grasslands" (“US Forest Service Mission,” 2014). Therefore it carries the responsibility of directly managing 192 million acres of national forest and grasslands and leading the management of the Nation's 731 million acres of forests, providing technical and financial assistance for their management ("US Forest Service, Roles and Responsibilities,”2014).

\section{Importance of Participation}

The National Environmental Policy Act of 1969, the Federal Advisory Committee Act of 1972, the National Forest Management Act of 1975, and the Federal Land Management and Policy Act of 1976 are some legal instruments that include provisions about public participation in the management of natural resources in the United States (Daniels \& Walker, 2014). The number of appeals by those affected by USFS processes, in the 80's and 90's, shows the extent of public discontent (Daniels \& Walker, 2014). Factors related to this lack of success include inadequate training of USFS personnel to deal with multi-party conflict, inadequate motivation to manage the conflict and complexity of issues that may overcome the conflict management structure (Daniels \& Walker, 2014).

When approaching the public and promoting participation in public matters agencies should make sure that true participation is really achieved (Arnstein, 1969). Arnstein (1969) separates citizen participation in degrees, including rungs at each degree as follows: 
1) Non participation (manipulation and therapy),

2) Degrees of tokenism (informing, consultation, and placation), and

3) Degrees of citizen power (partnership, delegated power, and citizen control)

According to Arnstein, the first level participation is artificially created by some to replace real participation, where the goal is not to enable people but "to enable power holders to 'educate' or 'cure' the participants." In the second level the "have-nots" can be heard and have a voice, but they still don't have the power to decide. The third level allows the "have-nots" to have full managerial power over the decisions. It is in this level where true participation of the public occurs.

Public involvement contributes to the effectiveness of decision-making because those with authority to make decisions and those affected by decisions reach a common ground. Benefits of public participation in natural resources management include the sense of ownership or empowerment (McGurk, 2003), allowing the opportunity for multiscalar planning of private forest (Rickenbach et al., 2011).

\section{Cross Boundary Cooperation}

The implementation of the Northwest Forest Plan caused a reduction of Forest Service program offices and employees during Clinton's administration (MacCleery, 2008). This left the USFS with a reduced force having to attend a huge clientele. Reduction in the number of employees pushed the USFS toward the establishment of partnerships for the administration of federal lands (Seekamp \& Cerveny, 2009).

Between 1995 and 1996 the Environmental Protection Agency published three volumes of case studies named: "The Ecosystem Approach: Healthy Ecosystems and Economies.” Those 
publications were a response to public and private sector requests for addressing environmental and economic matters enhancing public participation and involvement in agency decisions ("The Ecosystem Approach," 1995.) These volumes contain several recommendations to enhance collaboration across boundaries. Shared vision (of ecosystem management), flexibility of Federal Advisory Committee (FACA) procedures, more extensive use of FACA, technical assistance to private landowners and the support to existing grass root efforts were recommended to improve partnerships with non-federal stakeholders ("The Ecosystem Approach," 1995).

The need of cross-boundary cooperation is contained within the USFS approach to landscape scale conservation. This approach embraces the concept along with the philosophy that all lands, multiple users, management objectives and partners are important, and provides a new venue to face the challenge of climate change (Tomosy et al., 2012). This approach considers land management problems and solutions on a broad scale, providing flexibility to address problems and risks at the appropriate level (Tomosy et al., 2012).

The importance of cooperative partnerships to address issues across boundaries emphasizing the landscape level approach is illustrated in the statements of USFS Chief Tom Tidwell when referring to the Memorandum of Understanding between the Bureau of Land Management, the USFS and the National Association of Counties ("US Department of the Interior, BLM," 2014). After signing the Memorandum in March 2013 he stated: "It's essential that we continue our strong, productive partnership with the National Association of Counties" and "We appreciate the association's interest and participation in the wide variety of land management issues we face every day on forests and grasslands across the country" ("US Department of the Interior, BLM," 2014). 
Cross-boundary cooperation is defined in this study as "voluntary behavior whereby one or more landowners account for the plan and practices on adjacent and/or nearby properties" (Rickenbach et al., 2011). Another form of forest management across boundaries is collaborative forest management (CFM). This form of management is crucial to move from within the boundaries of small scale community forest to large public resources (Carter \& Gronow, 2005). To Carter and Gronow (2005) CFM is an operational partnership where main shareholders come together to manage a particular forest under different tenures. The need for operational partnerships arises due to complex issues/crisis (social, institutional, silvicultural) (Carter \& Gronow, 2005). In this case private participation occurs in the form of community-company partnerships, where companies seek collaboration with forest partners to reduce sabotage risk and secure access to raw materials, among other objectives (Carter \& Gronow, 2005).

Past efforts to promote sustainable forestry practices on the nation's family forests have included financial incentive programs. However, a visit by a professional to the landowner, which included walking the land, ("to walk the land" Kilgore, 2007, p. 1), was perceived by owners as a greater assistance regarding the management decisions about their land, than the assistance received from the incentive programs. As part of the policies to preserve forests for the wellbeing of society and to understand how to manage forests under changing conditions, the USFS has been promoting landscape scale stewardship and cross-boundary collaboration through research, publications, programs and projects covering a wide range of issues. This federal agency has been working with public and private partners "to promote landscape scale conservation to restore ecosystems on a landscape scale" (Tidwell, 2013). Because landscape stewardship is a relatively new policy direction, the USFS has produced documents such as "Cooperating across boundaries, Partnership to conserve open space in rural America" and the 
"Landscape Stewardship Guide". These publications and program efforts have been supported by information gathered from woodland management surveys, most notably the National Woodland Owner Survey (USDA, FS, 2013). An integral part of landscape scale forest ecosystem management takes into account natural processes and social systems, emphasizing collaborative decision making that considering geographic areas and ownership of the landscape. Currently, the Forest Service Planning Rule (USDA, FS, 2012), and its mission for sustainable forest management on public lands offers opportunities to include community values in the management of public forests and to incorporate the landscape context in management.

There is a need to conserve and manage ecosystems across multiple spatial scales (Rickenbach et al., 2011). However the predominance of private small properties ( $<250$ acres) and an "ownership-centric" "framework that is largely driven by and evaluated using parcel scale metrics" (Rickenbach et al., 2011, p.1) offers a challenge. Since neither ecosystems nor landscapes stop at a particular property boundary, public policies that incentivize management of private lands at larger scales should be considered (Finley, 2006). According to the "Landscape Stewardship Guide" (p.1) the definition of Landscape Forest Stewardship (LSFS) "involves bringing together the stakeholders in a community of place or community of interest to address resource-based issues of mutual concern". In this scenario LSFS planning becomes a potential tool to address several issues related to forest health, especially in those areas that are facing existing landscape problems (LSFS Proposal 2011). Rickenbach et al. (2011), classify crossboundary cooperation in three broad areas: “(1) landscape feasibility and impacts, (2) landowner interest and receptivity, and (3) promotion of cross-boundary cooperation by the institutional environment" (p.92A). Those broad areas of cross-boundary cooperation take into account coordination of small holdings, shared values and outcomes and policies that are important when 
working at a landscape scale. Landscape scale conservation it is multijurisdictional, multipurpose and multistakeholder (McKinney, Scarlett \& Kemmis, 2010), qualities that are essential to address the threats related to development, parcelization, fire and others mentioned previously. Landscape scale conservation could be thought of as an incipient context to design, finance, manage and plan projects of substantial social, ecological and economic value (USDA, FS, 2009).

Natural resources agencies interested in motivating woodland owners toward landscape scale goals will need to account for differences in landowner perceptions of the need to address the diverse issues. They must also consider woodland owner concerns, apprehensions, and trust of various types of neighbors and ownerships (Fischer \& Charnley 2012). Risk perception influences mitigation behavior making people more or less willing to prepare or prevent a dangerous event, attempt a new management technique, or take other actions that are unfamiliar. An assessment of risk perception could be used by natural resources agencies when promoting cooperation in a landscape with multiple owners (Fischer \& Charnley, 2012).

Numerous examples of successful cross-boundary cooperation exist in the USA and abroad. In the USA, we have seen cross-boundary cooperation for wildfire control, weed control, pest management, and watershed management. Water pollution is another example of a problem that extends beyond a single property's boundaries and one that involves several actors. One example of successful restoration efforts involving partnership of government, industry and nonprofit groups in USA and Canada is the Detroit River International Wildlife Refuge (Delloite, 2011). Through this partnership a disastrous situation caused by industrial pollution was reduced. Pollutants were dredged, and restorative criteria about benthos degradation, water, fish and wildlife consumption were established. From 2001-2006, 4,985 acres were preserved, 
concrete infrastructure was replaced with non-permanent structures (soft shore) in 25

engineering projects, and conservation projects for a sum greater than $\$ 11$ million were leveraged (Delloite, 2011).

The creation of cooperative networks for the detection of and rapid response to invasive alien species is a further example of cross boundary collaboration that can now be found around the world (Simpson et al., 2009). These networks usually work locally but have a national or international impact. Communication and project networks provide the information that facilitates these cooperative initiatives. More importantly, sharing the information lowers costs while improving the capabilities of prevention and early detection of invasive alien species (Simpson et al., 2009). Participation of volunteers in collecting information and testing control methods has greatly increased efficacy of invasive alien species control. The use of interagency councils and committees as part of the "US National Invasive Species Management Plan" helps interagency partnering, since they offer a forum to approach the complete array of issues (Simpson et al., 2009). The councils established in the US (Simpson et al., 2009) to date are:

- State Interagency Invasive Species Council (one in Oregon)

- Governor's Invasive Species Council (one in Pennsylvania)

- State Interagency Task Force (one in Maryland that includes agencies and organizations).

- State Invasive Species Council (one in Delaware, formed by nonprofit organizations). The collaborative initiative for biodiversity management, developed in Oregon and Washington by the Pacific Northwest Research Station, is another example of collaboration with stakeholders to identify challenges for biodiversity management and for the development of management tools to meet those challenges (Nelson, White \& Molina, 2006). This initiative aims to facilitate mutual understanding of biodiversity goals by developing long term partnerships to address 
future problems. As a result stakeholders are able to identify biodiversity challenges, and establish a need for information and the best technology transfer methods (Nelson, White \& Molina, 2006).

\section{Motivations to collaborate}

Common elements motivate collaboration across properties and diverse ownerships. These include: personal benefits (timber sales), public benefits (clean water, recreational spaces) reaction to stimulus or threats (flooding, wildfires, pests, ecosystem destruction, environmental concerns, endangered species), and the role of government (Kittredge, 2003). The collaborative approach to forest management is frequently used in response to a crisis, which is usually the case in public forests (Carter \& Gronow, 2005).

Recent studies show that inheritance status is an explanatory variable for some behaviors and motivations of woodland owners (Majumdar et al., 2009). Using information from the NWOS

Majumdar et al. (2009) found that those with inheritor status were more active and aggressive forest managers than non-inheritors in both timber and nontimber activities. Also, using information from the NWOS another study found that environment, recreation, investment, home and family are some of the motivations to own forestland (Bengston, Asah, \& Butler, 2011). Motivations are interrelated to objectives; a study conducted in Sweden found that objectives/motivations related to conservation, utilities, amenities, and economic benefits are the driving forces that include general values for actions in forestry (Hugosson \& Ingemarson, 2004).

The rationale of collaboration implies social justice and equity, requiring frequent readjustments that entail flexibility and trust (Leong et al., 2011; Cantiani, 2012). In a participatory process it 
is likely that interests, perceptions and values of stakeholders will conflict, requiring compromise to reach a satisfactory solution (FAO-ECE- ILO, 2000). All parties should have an equal opportunity to express their opinions and to stress their rights and interests. Facilitating this requires the creation of a climate of "good faith" (FAO-ECE- ILO, 2000). Conflict management is used to stimulate the process of empowerment among the individuals who are part of collaborative projects, expanding their awareness of their own rights and responsibilities regarding the management of their forests (Cantiani, 2012). According to Carter and Gronow (2005) indicators of good governance include transparency, compliance with rules, accountability, decentralization, gender sensitivity and bidirectional flow of information between participants.

\section{Barriers to Cross Boundary Cooperation}

Among the several examples of public involvement in collaborative efforts across boundaries, some cooperation initiatives respond to needs of communities, and others arise in response to specific interest groups. The need for information (clear schemes, examples, etc.) required by private forest owners before committing to participation in cross-boundary cooperation has arisen in several studies and has been identified as a barrier ( Finley et al., 2006).

Systems barriers are identified as the biggest obstacles to collaboration. Leong et al. (2011) found that if public involvement is not incorporated into agency culture, the support needed for success is missing. Cheng et al. (1993) showed that the USFS's lack of knowledge on how to be more effective, lack of resources, and stakeholder resistance to change are also barriers to public participation. Agency unwillingness to recognize the value of local knowledge, placing scientist (technical) knowledge above local knowledge, and trying to keep control of public resources are other barriers to collaboration (Carter \& Gronow, 2005). 


\section{Parcelization and Fragmentation}

Parcelization and fragmentation are threats to forests in the United States (USDA, 2006; Heilman et al., 2002). According to the literature, as the size of the parcel is reduced the possibility of carrying out management practices is reduced (Hatcher et al., 2013). The smaller the forest tract the more management objectives owners have and the more difficult their management for timber, water or wildlife (USDA, FS, 2006). Lacking economies of scale, small parcels impact the potential and incentives for the owners to practice forestry (Hatcher et al., 2013).

Parcelization, understood as the division of land into smaller tracts due to change in ownership (e.g. division by inheritance or sale) also contributes to fragmentation, and compromises the quality of habitat (Rickenbach et al., 2011). Fragmentation is the subdivision of forest into smaller patches due to conversion of forest land to other uses (Heilman et al., 2002). It "refers to the disturbance zone beyond the foot print of development" (USDA, FS, 2006. p.11). Fragmentation affects the ability of the USFS to respond to the needs of land owners and to manage National Forest and Grasslands, placing an additional burden on the USFS for the management of forest lands.

Fragmentation is often brought about by residential development, which is the case in West Virginia (Widmann et al., 2008). Over 10 million acres of forest land nationwide were lost to development between 1982 and 2001 (USDA, FS, 2006).

\section{The National Woodland Owner Survey}

Data collection through the USFS's National Woodland Owner Survey (NWOS) began in 1953 and was focused on the size of woodland holdings and number of woodland owners (USDA, FS, 2008). More complete NWOSs were started in 1978 (Birch, 1982) and were very similar to 
those conducted today, which include demographics (current occupation, gender, income, and education), type of ownership, reasons to own, concerns and future plans for the property. Those issues, among others, are included in this study.

According to the NWOS, $3 \%$ of private US woodland owners have management plans and only $16 \%$ seek advice (Butler \& Leatherby, 2004). The number of woodland owners in the Northern United States increased from 3.8 to 4.7 million between 1993 and 2006, while the average size of landholdings decreased from 25 acres to 20 acres in the same period (Butler \& Ma, 2011). It is obvious that attending to the needs of the increasing number of private owners poses a challenge. How private owners manage their forest is of public interest since their combined decisions affect the landscape in a positive or negative way. Understanding the needs and concerns of family forest owners is crucial to keeping forest and ecosystems healthy. Social marketing is suggested by the Sustainable Family Forest Initiative to preserve forest cover and reach more private forest owners). To promote sound management more efficiently, effective outreach policies are needed (Butler, 2007).

The Sustaining Family Forests Initiative (SFFI) is an effort to better serve the needs of Non Industrial Private Forest owners. The SFFI used information from the NWOS to develop a set of "Tools for Engaging Landowners Effectively" that apply a social marketing approach to promote social changes among woodland owners to conserve and sustain their lands ("SFFI Tools," 2014). As a reflection of their attitudes, level of engagement, and interest in forest management, family forest owners are classified by SSFI into four segments: 1) woodland retreat 2) working the land 3) supplemental income, and 4) uninvolved (Butler et al., 2007). Main barriers to good stewardship identified in this approach included: "Perception that woods manage themselves" "Fixed ideas about what is good for woods"; "Skeptical of most programs 
that impose restrictions on land use", "Lack interest and/or knowledge to improve/manage their woods."

SFFI also uses Prime Prospect analysis as another way to look at family forest owners. Using data from the NWOS, the family forest owners are divided in four categories: 1) Prime Prospects (have a stewardship mindset but are not managing their woods, 66\%); 2) Model Owners (have a stewardship mindset and are taking actions recommended by natural resources professionals, 7\%); 3) Opportunists (doing some management but not actually stewardship oriented, 12\%); and 4) Write-Offs (no sustainable management and no stewardship mindset, 14\%) ("SFFI Tools," 2014).

\section{Research Objectives}

One research question was developed for this study as follows:

- What are the main motivations and barriers for woodland owners to collaborate across boundaries?

To find out what motivates woodland owners to work together and how they could be more inclined to work on a landscape scale, in this study we look at their attitudes and interest toward cross boundary cooperation, their definition of landscape (threats, desirable features, most important resource to protect), their involvement in conservation organizations, their woodland activities and their demographic aspects. Results obtained could be used in a social marketing approach to change attitudes and behaviors toward forest stewardship.

\section{CHAPTER 3: METHODOLOGY}

\section{Introduction}

This chapter describes in detail the methods and materials used for this study starting with the 
selection of the study site, followed by data collection and then data analysis. To better explain data collection methods, this is divided in three project phases: 1) the selection of the population to be sampled, 2) establishing contact, and 3) mailed questionnaire. The first section describes the instruments used in collecting the data and the procedures that followed. The second part refers to the postcard and letter of introduction to establish the initial contact with the woodland owners, providing them with the opportunity to ask for more information. The third refers to the survey questionnaire conducted to do the assessment.

It is important to note that this research study was part of a broader study to investigate the potential for successful landscape-level natural resources projects in West Virginia. The project referred to as the Landscape-Scale Forest Stewardship Feasibility Study (LSFS Proposal, 2011) had as its primary goal to gather information from five priority areas in the state related to citizens' opinions, their perspectives of natural resources management, and perceived threats to their environment.

\section{Phase One}

\section{Sampling methods}

Five geographic areas were used to investigate cross-boundary forest management challenges and motivations across the state of West Virginia. The areas had been selected as priority areas of concern for the broader study LSFS project that aimed to explore and understand landscape scale resource management issues across the state. Some of the attributes of these areas that were of interest for this larger landscape project were that they were in close proximity to other states with which partnerships could easily be expanded, and that they are known to have high levels of fragmentation, parcelization, and development.

The study areas are located along the main transportation corridors of the state of West Virginia 
(Figure 3) and are described below:

1. Eastern Panhandle (EP). Interstate 81, connecting PA, MD, VA, and WV, including Jefferson, Berkeley, and Morgan counties in WV.

2. Technology Corridor (TC). Interstate 79, between Morgantown and Clarksburg, including Monongalia, Marion, and Harrison counties.

3. Metro Valley (MV). Interstate 64 from Charleston, WV (Kanawha County), through Putnam and Wayne counties to Huntington, WV (Cabell County).

4. Northwestern (NW). US Route 50 including Clarksburg, in Harrison County, WV on the east, and Parkersburg, in Wood County, WV on the west.

5. Northern Panhandle (NP). The Interstate 70 corridor, including the WV counties of: Hancock, Brooke, Ohio, Marshall and Wetzel.

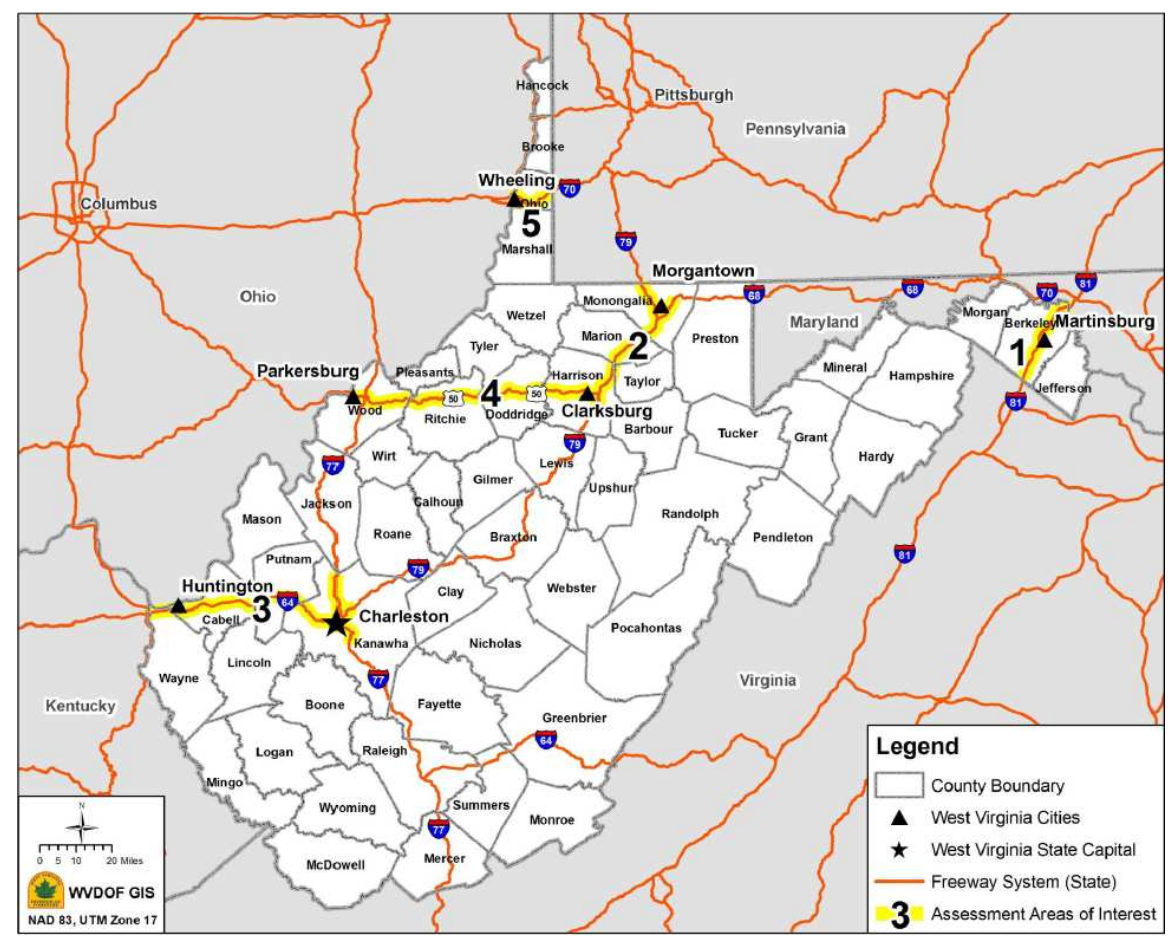

Figure 3: Map of WV counties within the five geographic areas of study. 
Within each of these areas, one or more counties were selected as a focus of this study.

Selections were based on whether tax records could be accessed and the location of the nearest major transportation corridor. In an attempt to avoid encountering areas with "survey fatigue," counties that had recently been surveyed with one or more known woodland owner mail-based questionnaires were considered as less desirable for sampling. The counties selected for data collection in the five areas were: Berkeley (EP), Cabell (MV), Jefferson (EP), Marion (TC), Marshall (NP) and Ritchie (NW). Berkeley and Jefferson are in the same region; both were chosen because their residents are involved in more cross-boundary activities (especially watershed initiatives) and to provide an opportunity to determine whether woodland owners in counties in close proximity have differing viewpoints about natural resources issues. Initially Ohio County was considered for the sample but was discarded because permission to use tax address records could not be obtained from the county assessor. Instead, Marshall County was chosen as the NP County.

\section{General Information about Counties Used in Project}

As of the 2012 census (U.S. Census Bureau, 2012) Ritchie County had the lowest population density (23 per sq. mi.), and Cabell the highest (343 per sq. mi.) (Table 1). Berkeley was the second most densely populated county with 324 persons per sq. mi. Jefferson County had the highest percentage (28\%) of people in the group age $25+$ that had completed a Bachelor degree or higher; also the highest annual per capita income.

Table 1: Demographics related to population, education, and income.

\begin{tabular}{lllllll}
\hline Region & $\begin{array}{l}\text { Sample } \\
\text { County }\end{array}$ & Pop.* $^{*}$ & $\begin{array}{l}\text { College } \\
\text { degree } \\
(\boldsymbol{\%})\end{array}$ & $\begin{array}{l}\text { Annual per } \\
\text { capita }_{\text {income }^{\dagger} \mathbf{( \$ )}}\end{array}$ & $\begin{array}{l}\text { Area } \\
\text { (sq. mi.) }\end{array}$ & $\begin{array}{l}\text { Pop. } \\
\text { density }^{*} \\
\text { (\#/sq. mi.) }\end{array}$ \\
\hline EP & Berkeley & 107,098 & 19.4 & 26,074 & 321.14 & 324.4 \\
\hline
\end{tabular}




\begin{tabular}{llrllll}
\hline MV & Cabell & 96,974 & 25.2 & 23,024 & 281.02 & 342.8 \\
EP & Jefferson & 54,504 & 27.8 & 29,655 & 209.64 & 255.2 \\
TC & Marion & 56,678 & 20.0 & 22,295 & 308.74 & 182.7 \\
NP & Marshall & 32,685 & 13.5 & 24,297 & 305.43 & 108.4 \\
NW & Ritchie & 10,243 & 12.0 & 18,773 & 451.99 & 23.1 \\
\hline
\end{tabular}

*Year 2012, ${ }^{\dagger}$ period 2008-2012, ${ }^{\ddagger}$ Year 2010

\section{Sample population and survey instrument}

The close integration of this research with the larger LSFS project necessitates a description of LSFS outreach contact methods and how these relate to the subsequent deployment of our crossboundary survey instrument. Essentially the LSFS project consisted of a cover letter and a postage-paid return postcard inviting woodland owners to participate in the project. This was followed up by a mailed questionnaire to those same woodland owners (the main effort of this study), and then a series of community outreach meetings were carried out in May-June 2014.

\section{Selection of woodland owners}

County Tax Assessors in each of Berkeley, Cabell, Jefferson, Marion, Marshall and Ritchie counties were contacted for permission to access 2013 tax parcel information. Tax records were requested that comprised only those woodland owners having a minimum of ten woodland acres per parcel. Berkeley, Cabell, and Marion counties maintain their own tax database and provided parcel information in Microsoft Excel workbooks. The West Virginia Tax Department provided files in text format for Jefferson, Marshall, and Ritchie counties. In Berkeley County, the WV Managed Timberland Tax Program was kept in a separate file and was merged with other parcel data for sample selection.

Text files were imported into spread sheets using the text import wizard by selecting a fixed width to define column width. Addresses and owners' names were reviewed and cross-checked 
with the initial file to make sure that the information was properly transferred. To avoid duplication where a landowner might be sent more than one questionnaire, parcel addresses of woodland owners were screened in the following manner. Parcel numbers and names were copied in a separate spread sheet to evaluate the number of parcels in each county. Woodland owners with one property were coded with a "0". Woodland owners with two or more properties had the first entry coded with a "1" and all other parcels coded with a " 2 ".

All woodland owners were assigned an ownership type using the following categories: 1=Private Individual, 2=LLC or LLP/Trust, $3=$ Corporate and 4=Public. Properties identified as public had the name of a public office or body (e.g. State of WV, Bureau of Commerce, Board of Education) while those considered as corporate included the abbreviated words "Inc" or "Co". In most of the counties between 94-97\% of ownership fell in the Private Individual type except for Jefferson County where $73 \%$ fell in this category and $18.67 \%$ fell in the LLC, LLP/Trust type.

To calculate sample size both acreage and number of woodland owners were initially taken into account. But because results showed little relative difference between these measures when compared across counties (Table 2), the number of woodland owners was chosen as a sampling selection metric. No discrimination by ownership was made when selecting the random sample. This sample was selected by assigning a random number to each of the unique parcel owners. The final list of woodland owners and the associated ownership and parcel information was sorted in ascending order of the random numbers. Time and funding were limited and led to a selection of 1200 total woodland owners to guide our sampling protocol. The number of responses needed for the study was set at 264 using a confidence level of $90 \%$ and a confidence limit of plus minus 5\%. A basic target was set to assure a sample of at least 30 per county, a 
number generally accepted as a "large" sample (Van Voorhis \& Morgan, 2007; "Survey Sample Size," 2014). Other recent woodland owner surveys that used a mailed questionnaire obtained at least a 20\% response rate (Joshi \& Arano, 2009; McCuen, 2012), therefore a minimum of 150 questionnaires per county were needed to attain the desired 30 responses per county. The number of woodland owners in each county was expressed as a percentage of the total number of woodland owners as detailed in Table 2. Considering that the total number of woodland owners for the 6 counties was 7482, initially a sample of 1200 was decided and for each county the sample size was then determined by multiplying 1200 by the respective percentage of woodland owners. To ensure a minimum of 30 responses per county the sample size from Berkley and Jefferson counties was increased to 150 , resulting in 1330 total questionnaires. Parcels that had an incomplete or no address were removed from the random sample and a supplemental address was added.

Table 2. Sample size and expected response rate

\begin{tabular}{|c|c|c|c|c|c|c|c|}
\hline \multicolumn{8}{|c|}{ Acreage and \# of owners without duplicates } \\
\hline & Marion & Cabell & Berkeley & Ritchie & Marshall & Jefferson & Total \\
\hline \# Owne & 1905 & 2218 & 790 & 981 & 1321 & 267 & 7482 \\
\hline Acres & 59260 & 95943 & 35233 & 45516 & 47884 & 9298 & 293134 \\
\hline$\%$ num & 25 & 30 & 11 & 13 & 18 & 4 & \\
\hline$\%$ ac & 20 & 33 & 12 & 16 & 16 & 3 & \\
\hline & \multicolumn{7}{|c|}{ Number of questionnaires to send based on 1200 as a total number } \\
\hline Total & Marion & Cabell & Berkeley* & Ritchie & Marshall & Jefferson* & \\
\hline \multirow[t]{5}{*}{1200} & 306 & 356 & 127 & 157 & 212 & 43 & \# Owners \\
\hline & 243 & 393 & 144 & 186 & 196 & 38 & Acreage \\
\hline & \multicolumn{7}{|c|}{ Expected response } \\
\hline & Marion & Cabell & Berkeley* & Ritchie & Marshall & Jefferson* & Total \\
\hline & 61 & 71 & 25 & 31 & 42 & 9 & 240 \\
\hline
\end{tabular}


The questionnaire mailed for this study was preceded by an invitation letter (Appendix A) and prepaid postcard (Figure 4) announcing the LSFS project. Following that letter, a modified Dillman (2007) procedure was carried out with the sending of: a) a postcard announcing the upcoming survey, b) a survey questionnaire (first mailing), c) a reminder postcard, and d) a resending of the survey questionnaire (second mailing) to non-respondents (see all in Appendix $\mathrm{C}, \mathrm{D}, \mathrm{E}$ and $\mathrm{F}$, respectively). A mailed survey was used due to the cost and the inability to use other survey means (because phone numbers were not readily available).

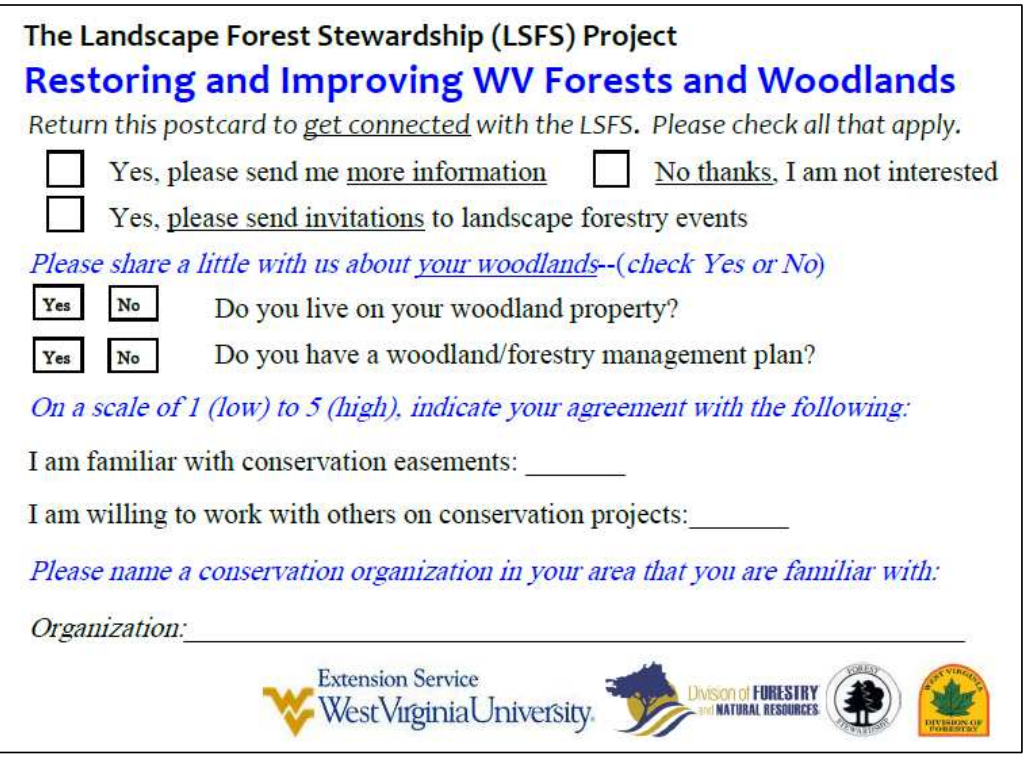

Figure 4: Prepaid mail back postcard

\section{Phase Two}

Pre-survey contact with selected woodland owners

The LSFS engagement process used a postcard (Figure 4) to invite woodland owner participation in the landscape forest stewardship project and to gather some initial information about the woodland owners and organizations that work in natural resources conservation in their respective areas. The postcard contained 7 answer choices and one fill- in- the- blank question (Figure 4). Questions were asked about woodland owners' familiarity with conservation 
easements and willingness to work in conservation projects on a scale from 1 to 5 , one being the lowest. Woodland owners could mail back the postcard and request an informational package and/or be invited to future community outreach education events, or decline to participate.

On December 5, 2013 a total of 1331 prepaid 5.5" x 4.25" postcards were mailed along with a cover letter stating the objectives of the LSFS project; 6" x 8" manila envelopes were used for this. Every envelope had a distinctive 5.25" x 3.25" WVU sticker and a 1"x 2.75" sticker on top of it with the mailing address. Each address was linked to its code which was placed on each postcard using a small label.

Since the postcard offered the possibility of asking for additional information, an informational package (Appendix B) was prepared containing the following: a cover letter, a magnet related to the WV Woodland Stewards social network site, the Quick Start Guide for Landscape Stewardship Managers brochure, a fact sheet about the WV Forest Stewardship Program, and a leaflet summarizing the Landscape Stewardship Approach to Forest Management.

Bad addresses identified in the first mailing were removed from the sample and other woodland owners from the random list were included to substitute those. In some cases a new address was provided by the United States Postal Service (USPS) and was used subsequently. Every reason for a returned postcard was recorded.

\section{Phase Three}

\section{Mailed Questionnaire}

The survey questionnaire was designed to parallel a study conducted in New England on crossboundary activities. Our questions were taken (with permission granted by one of the authors) from Finley et al. (2006). Their study was conducted in Franklin County, Massachusetts to 
evaluate private forest owners' attitudes in cross-boundary cooperation. Included in the survey there were questions on reasons for owning forestland, attitudes, actions, and barriers regarding cross-boundary cooperation. Finley et al. (2006) developed typologies of private forest owners that could be targeted in the future to help policy makers to promote cooperation beyond individual parcel owners. The design of Finley et al. (2006) was appropriate for our study because it covered our research question. By using their queries, we were able to explore how willing private forest owners from West Virginia are to engage in cross-boundary collaboration, what are the barriers to it, why do they own woodland, and the likelihood of having them participate in cooperative activities as a first step toward landscape scale projects.

The questionnaire included background information, instructions for completion, and then a confirmation of woodland ownership followed by 29 questions (Appendix D). The majority of the questions were close ended. However, keeping in mind the need to collect qualitative data regarding attitudes, perceptions of landscape, and participation in conservation organizations, specific sections with open ended questions were included (Table 3). The survey questionnaire was divided in seven sections as follows:
a) Woodland property ownership,
b) Woodland activities,
c) Defining landscapes,
d) Cross- boundary cooperation,
e) Reasons for owning forestland,
f) Conservation organizations,
g) Cooperative activities, and
h) Demographics. 
Table 3. Open ended questions to assess perceptions and attitudes of woodland owner regarding ownership, landscape- scale stewardship.

\begin{tabular}{|c|c|}
\hline Theme & Questions \\
\hline Ownership & $\begin{array}{l}\text { What are your } 3 \text { top reasons for owning your property? } \\
\text { a. } \\
\text { b. } \\
\text { c. } \\
\text { What is the main reason for selling or transferring? (your property) } \\
\text { Main reason: }\end{array}$ \\
\hline $\begin{array}{l}\text { Woodland } \\
\text { Activities }\end{array}$ & $\begin{array}{l}\text { Name a few people that you talk to for advice for forestry or other } \\
\text { environmental conservation decisions on your woodland property. (You can } \\
\text { use relationships or roles; for example: sister, forester, lawyer, agency, etc. ) } \\
\text { a. } \\
\text { b. } \\
\text { c. }\end{array}$ \\
\hline $\begin{array}{l}\text { Defining } \\
\text { Landscapes }\end{array}$ & $\begin{array}{l}\text { In a few words, what is the geographical area you consider as your "landscape. } \\
\text { Geographical area: } \\
\text { What do you consider the most desirable feature of your woodland landscape? } \\
\text { Most desirable feature: } \\
\text { If you had to pick one of the natural resources within your landscape area to } \\
\text { protect, which would it be? } \\
\text { Natural } \\
\text { resource: } \\
\text { In your opinion what are the main threats to forestlands in your landscape } \\
\text { area? } \\
\text { Main threats: }\end{array}$ \\
\hline $\begin{array}{l}\text { Conservation } \\
\text { organizations }\end{array}$ & $\begin{array}{l}\text { Please list the organizations you participate with most frequently. } \\
\text { What are the most valuable benefits you get from participating in natural } \\
\text { resources organizations? }\end{array}$ \\
\hline
\end{tabular}

The set of questions to measure barriers to cross- boundary cooperation taken from the Finley et al.(2006) study are negatively worded; previous studies (Colosi, 2005) found that negatively worded survey items cause confusion and respondents take more time to answer those questions. 
We decided to include a new question containing an affirmative statement within the barrier set. The purpose of introducing it was to reduce respondent's confusion and to help place them in context with the survey. Relative interest of respondents was measured using Likert, binary or ordinal scale.

The questionnaire was submitted for review and feedback to a team of professionals, extension specialists and research faculty. To further validate the survey questionnaire it was sent to three woodland owners (Phyllis Mingo, Russ Richardson, and Michael Sieber). Feedback was used to modify the questionnaire. The survey questionnaire was mailed in 10" x 13" manila envelopes and labeling and coding was made in the same way used to prepare the initial postcards.

Following institutional policies, once all the instruments to collect the data were ready (and prior to the engagement process with the spell out), these were presented along with the proposal for the study to the WVU Institutional Review Board for approval. The exemption number 1310106954 was awarded

The first mailing of questionnaires was on January 28, 2014. After two weeks 1175 reminder postcards (Appendix E) were sent to those woodland owners from whom no response was received. In a last attempt to reach those that still did not answer, a second mailing of the questionnaire was mailed on March 10, 2014 (Appendix F).

\section{Assessment}

Survey items such as tenure, residency, age, sex, education, income, parcel size, perception of threats, perception of landscape, reasons to own forestland, attitudes/actions associated with cross-boundary cooperation (as well as barriers to it), and cooperative activities were used to 
measure characteristics of private forest owners, attitudes and perceptions toward cross-boundary collaboration.

To organize the data, an excel spreadsheet was used. Answers from each postcard and then the answers from the survey questionnaires were entered according to their respective case identifier codes. Since no additional sampling was made, to determine nonresponse bias and to be able to compare early respondents (those answering the first wave of questionnaires) with late respondents (those who answered after receiving the questionnaire a second time) (Lindner et al., 2001) response receipt dates were recorded. Following Lindner et al. (2001) procedure 3, variables related to suggested cooperative activities were used to establish if there were significant differences between early and late respondents. Using information from 2013 tax parcel information, a comparison of property size among respondents and non-respondents was used to establish if there were statistically significant differences between the two groups (Finley et al., 2006).

Responses from the postcards were recorded in a column for each question. A binary form $(0=$ no, $1=$ yes) was used for the first 5 items, while a Likert scale from $1=$ low to $5=$ high was used to record the answers to the next two questions. Response types for the postcards and questionnaires were classified as follows: $\mathrm{PR}=$ partial response (incomplete), $\mathrm{FR}=$ full response, $\mathrm{NR}=$ no response, $\mathrm{RF}=$ refusal, $\mathrm{BA}=$ bad address, $\mathrm{IN}=$ ineligible (does not own woodland), $\mathrm{D}=$ deceased These classifications were based on the 2011 AAPOR Standard definitions: "Less than $50 \%$ of all applicable questions answered (with other than refusal or no answer) equals break-off, $50-80 \%$ equals partial, and more than $80 \%$ equals complete". For practical reasons "break-off" was treated as refusal (only 3 cases). To maintain sample size, bad addresses identified from the postcard mailing were replaced (42) but bad addresses identified with the 
questionnaire were not. When recording responses from the survey questionnaire, the initial 4 entries (not numbered) were assigned a binary code. These entries measured interest in receiving the results of the survey, if the respondent owned forestland and the option of declining to respond. In question 1, about the number of properties owned, respondents could choose from 1, 2 or 3 and a 4 for more than three (details for other questions in Appendix D). Written responses were categorized and the percentages of respondents in each category were calculated.

Decisions regarding the data entry: in relation to the year of ownership, when the respondent established a period of time the earliest year of possession was taken, and when woodland parcels were located in more than one county the one coinciding with the code was chosen (e.g. C10001= Cabell)

Response rate was calculated considering the number of postcards and survey questionnaires mailed (deducting those that were returned undelivered, and those that were considered ineligible-do not own land), the number of refusals and the usable surveys.

\section{Variable reduction for attitudes related to cross-boundary issues}

Survey questions in Likert-type form were used to explore associations among 1) woodland owners' willingness to participate in cross-boundary management, 2) various measures related to owners' reasons for owning woodland properties, and 3) attitudes, actions, and barriers woodland owners associate with cooperative activities. Questions in Tables 8, 11 and 14 were treated as potential explanatory (independent) variables. In addition, physical and administrative characteristics of the property and respondent demographics were also considered as explanatory variables. The set of ten questions concerning proposed cooperative actions in Table 15 were treated as response (dependent) variables to establish differences in willingness to participate in 
cross-boundary activities. These questions were Likert items with a scale from $1=$ very interested to $5=$ not interested. A neutral category was set at a value of 3 .

Principal Component Analysis (PCA) was used to examine these sets of questions to reduce the number of variables into indices that could be used for subsequent analysis. PCA is a method that uses orthogonal transformation to reduce a large number of correlated variables into a smaller set of composite variables. The goal of using this variable reduction process was to produce composite variables for each group with a minimum loss of information.

The protocol in the variable reduction step first examined Spearman rank correlations in PROC CORR to assess opportunities for variable reduction, since it was expected many of these scaled items would be strongly correlated. The degree of correlations among the variable sets is an indication that the variables have some redundancy (Stevens, 1992). Using PROC FACTOR METHOD=ML HEYWOOD, Bartlett's of sphericity was used to test the significance of the correlations. This tests null hypotheses that 1) there are no common factors and 2) one factor is enough. PCA was then used to evaluate the variation in correlation matrices of the variables for underlying components. PCA was carried out using the FACTOR procedure and the METHOD=PRINCOMP in SAS 9.3 (SAS Institute, 2011). The selection of components used several methods, but relied primarily on the results of parallel analysis (Patil et al., 2008). Parallel analysis compares the 95th percentile of eigenvalues from random correlation matrices with correlation matrices of interest, that is, those in this study. A SAS program developed by O'Connor (2000) was used to carry out the parallel analysis. Finally, variables loading on a given component were tested for internal consistency (how similar they are) with Cronbach's $\alpha$, generated in the CORR procedure in SAS. Groups of variables (questionnaire items) with 
Cronbach's $\alpha$ greater than or equal to 0.70 were then used in Likert-type scales by taking the average values of the items.

Willingness to participate in cross-boundary activities variables (CA) were discretized into binary form. Regarding interest in factors associated with CA, 'very willing' and 'willing' categories were combined into one group while 'neutral', 'not willing', and 'very not willing' were combined into another. PROC logistic model was used to explore associations between CA (willingness to participate in CA) and other sets of independent variables. This model requires the comparison of sets of variables until just significant variables are left.

\section{CHAPTER 4: RESULTS}

Initially, 1330 woodland owners were selected from the five study areas (6 counties). The sample size increased to a total of 1374 due to replacement of bad addresses and one email request from a woodland owner to be included in the study.

\section{Mail Back Pre-Survey Postcard Results}

Of 1331 initial postcards sent out a total of 160 postcards were received back, of which 110 were usable responses, 30 were refusals and 18 were classified as ineligible (4 deceased and 14 did not own woodland). Of the initial list of woodland owners 62 postcards were not delivered due to bad addresses reducing the sample size to 1269 . This produced a response rate of $9 \%$ and a cooperation rate of $77 \%$ (AAPOR, 2011). Eighty-nine woodland owners requested an information package and of those 62 expressed interest in being invited to LSFS events.

\section{Landowner's forestry activities}

In response to the questions on the initial postcards, 58 respondents live on their woodland property and 15 have management plans. The majority of respondents (56\%) were unfamiliar 
with conservation easements (Figure 5). More than 40\%, however, were either somewhat or very willing to work with others in landscape conservation projects (Figure 5).

Respondents listed a total of 43 conservation organizations that work in their respective regions. Jefferson County respondents identified the greatest number and Ritchie County the fewest with only 2 organizations identified by 3 respondents. In Cabell and Marshall more than $50 \%$ of respondents could not identify any organization (none, N/A, not known or not sure) (see list in Appendix G). The Berkeley County Farmland Protection Board, the Land trust of Eastern Panhandle, and the Natural Resources and Conservation Service (NRCS) were mentioned at least 3 times, but most of the others only once. More public organizations were identified than private.

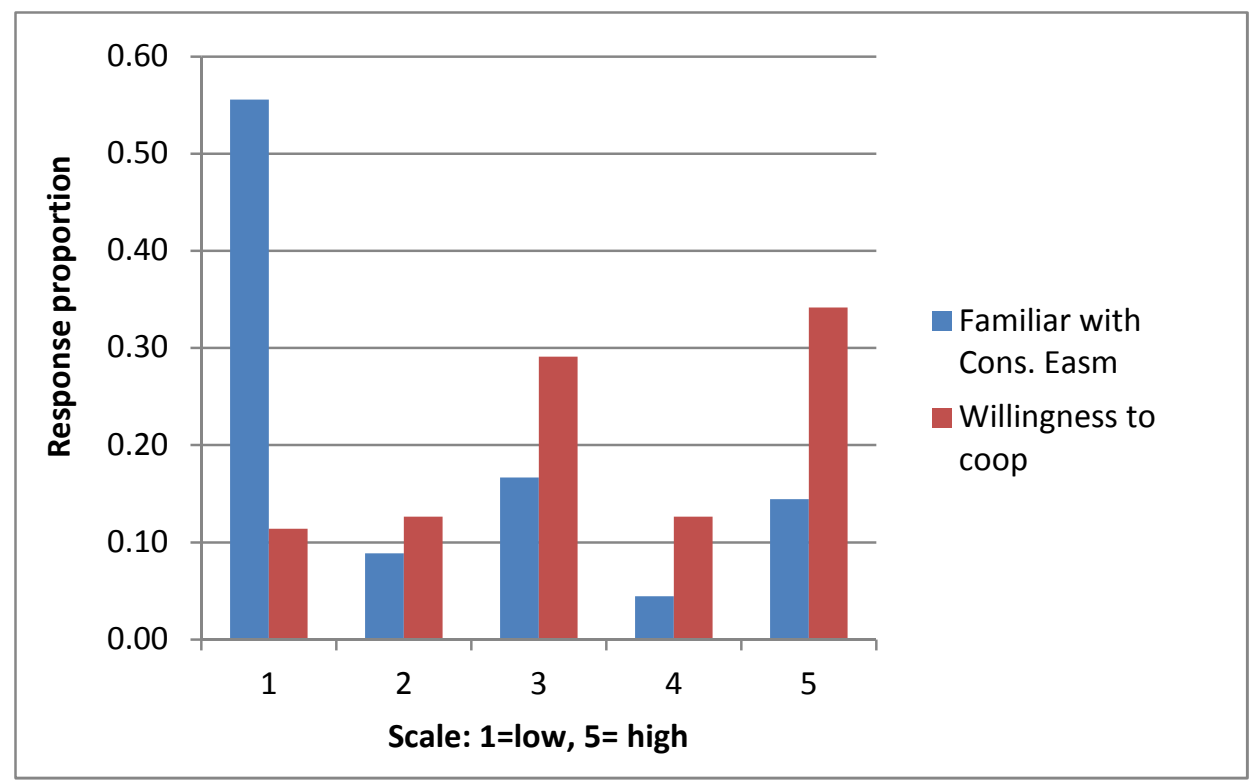

Figure 5: Postcard responses related to conservation easement and cooperation 


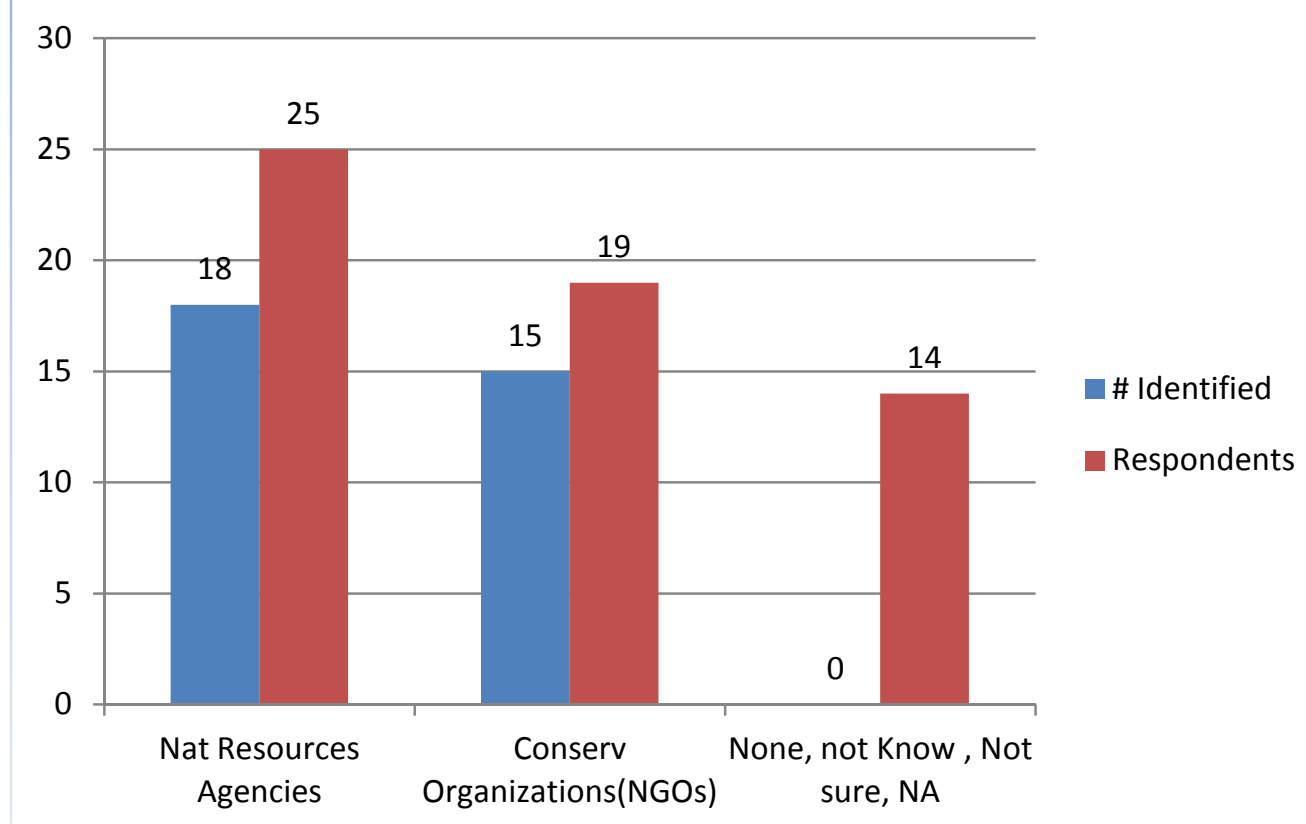

Figure 6: Public and private organization identified by postcard response

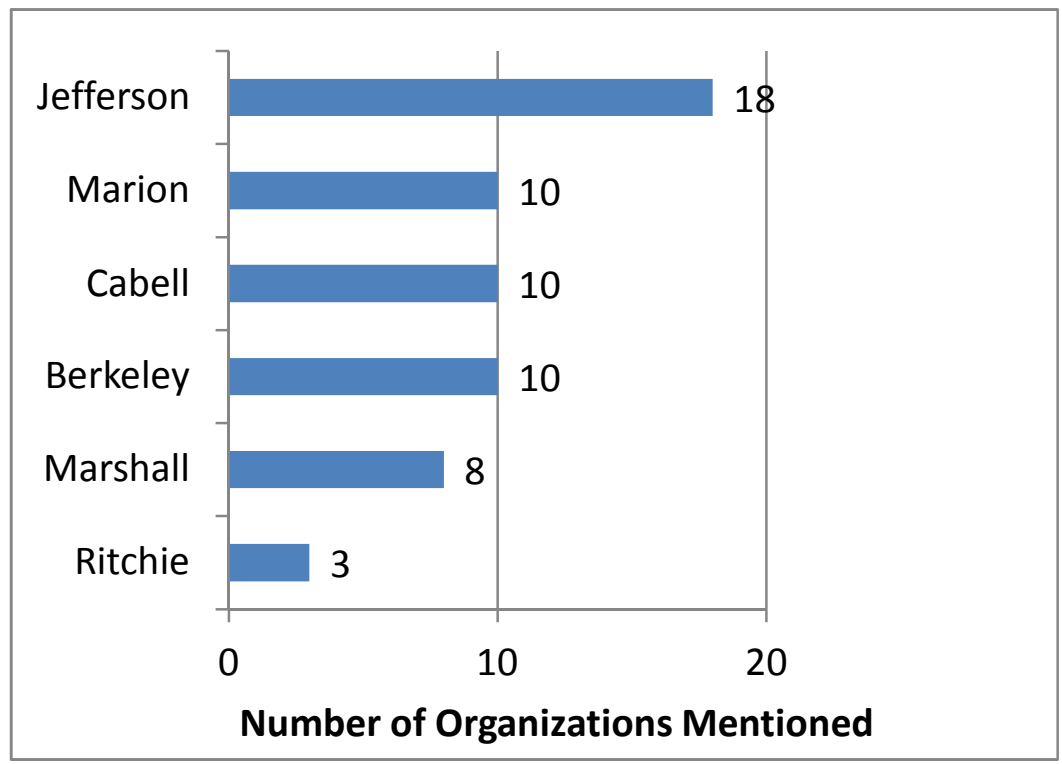

Figure 7: Number of organizations identified by postcard respondents/county 


\section{Mailed Questionnaire}

Forty two bad addresses identified with the initial postcards were replaced. However, following the replacement 23 more were considered undeliverable, reducing the sample size to 1309 . A total of 293 usable questionnaires and 155 refusals were received. This produced a response rate of $22 \%$ and a cooperation rate of $65 \%$.

Since no additional sampling was made to determine nonresponse bias we followed combinations of the procedures outlined by Finley et al. (2006) and Lindner et al. (2001). The procedure consisted of two methods:

a) Comparing respondents with non-respondents by one common attribute; and

b) Using the concept that late respondents are similar to non-respondents. With this method, a comparison of several key questions was made between early (those who answered within 6 weeks after the questionnaire was sent) and late respondents (Lindner et al., 2001).

The common attribute selected was parcel size. Using woodland acreage from 2013 tax records, analysis of variance indicated there were no statistical difference between the two groups $(F=$ 0.94, $p=0.3335$ ). The comparison between response rates among the targeted counties similarly found no statistically significant differences. Based on these tests and the response rate of the overall survey similar that obtained from preceding similar studies in WV we feel confident that these results can be generalized to the sampled population.

\section{Demographics}

Seventy four percent of respondents were males; $86 \%$ were 50 years old or older and of those $33 \%$ were between 60-69 years of age. More than half of respondents had at least an associate degree or higher (20\% Master, $18 \% \mathrm{PhD})$. Thirty three percent reported an average yearly 
income of $\$ 90,000+$ and a $4 \%$ reported an average income of less than $\$ 15,000$. Of those respondents that reported an occupation $43 \%$ were retired. Nine percent were in business occupations and a $6 \%$ were in STEM careers.

Purchase was the most common way of acquisition of woodland properties followed by inheritance. The majority of respondents possessed only one property (74\%). More than 50\% of respondents acquire their property between 1994 and 2013. Property was used as residence by $56 \%$ of respondents and $10 \%$ planned to move in the future. The most common ownership category was "Joint" (46\%) followed by "individual" (35\%); 19\% plan to sell their property. Average size of properties was 106 acres with an average of 66 acres of woodland.

\section{Open ended questions}

Respondents were asked to answer a few open ended questions pertaining to reasons to own, people they seek advice for conservation/forestry decisions, participation in organizations and benefits to participate. To better understand how WO perceive their landscape and what are their main concerns and interests in the subject, a section with four questions was developed to address the concept. This was done keeping in mind that this study will contribute to assess opportunities for landscape scale forestry projects in West Virginia. The four questions included were:

- What is the geographical area you consider as your "landscape"

- What do you consider the most desirable feature?

- If you had to pick one of the natural resources to protect which would it be?

- What are the main threats to forestland in your landscape area? 
For description of landscape the majority (54\%) provided responses defining the area ("valley and mountain at edge of valley", "woodland area on side of mountain"). Thirty nine percent of respondents used a description of what (landscape) is like ("Hilly, wooded, stream running through middle"). Responses were grouped by themes and $40 \%$ of those fell under "geographic feature" (Figure 8).

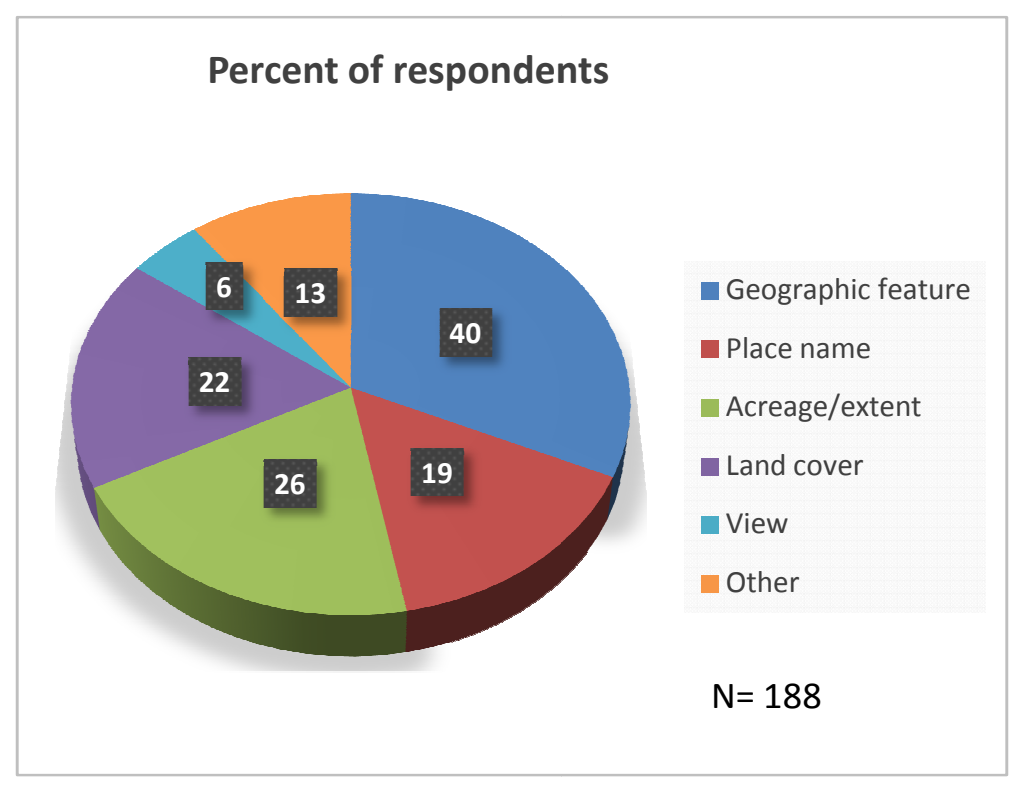

Figure 8: Themes used to group "landscape" descriptions and percent of responses

The "most desirable feature" identified was related to land use/cover with 37\% (Figure 9). Data was grouped in six main themes: view, economic benefits, privacy, supporting and cultural benefits and land use/cover 


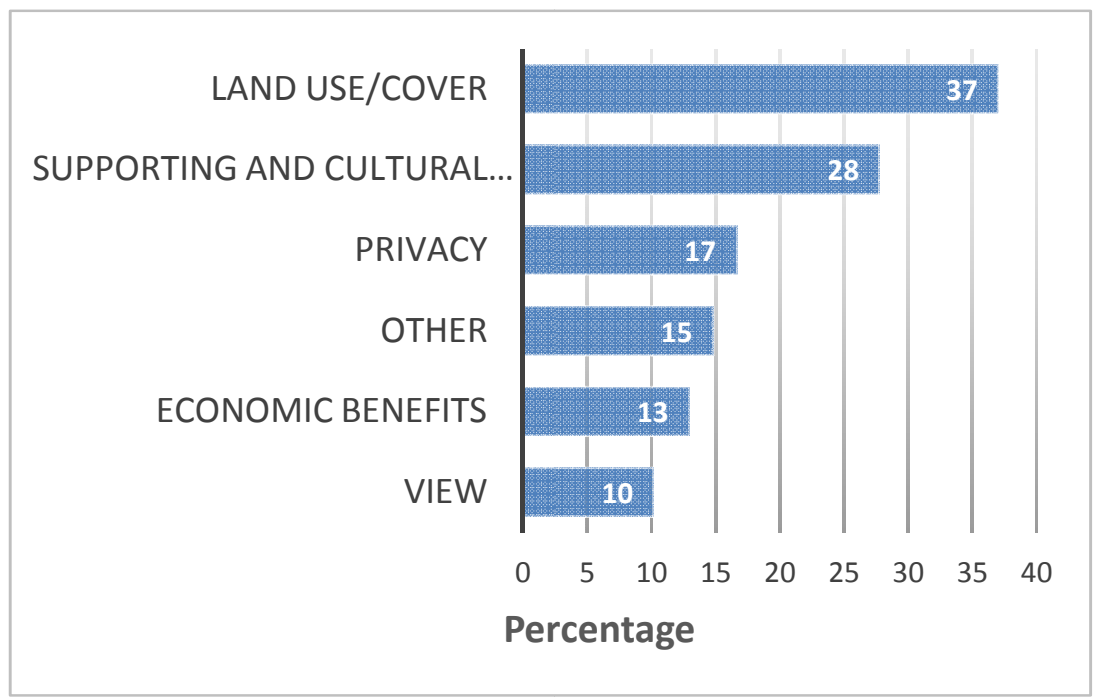

Figure 9: Percentage of responses by theme. Used to group "desirable features"

The "natural resource to protect" identified for the majority (48\%) of respondents fell into the theme "forest natural cover" followed by water (23\%).

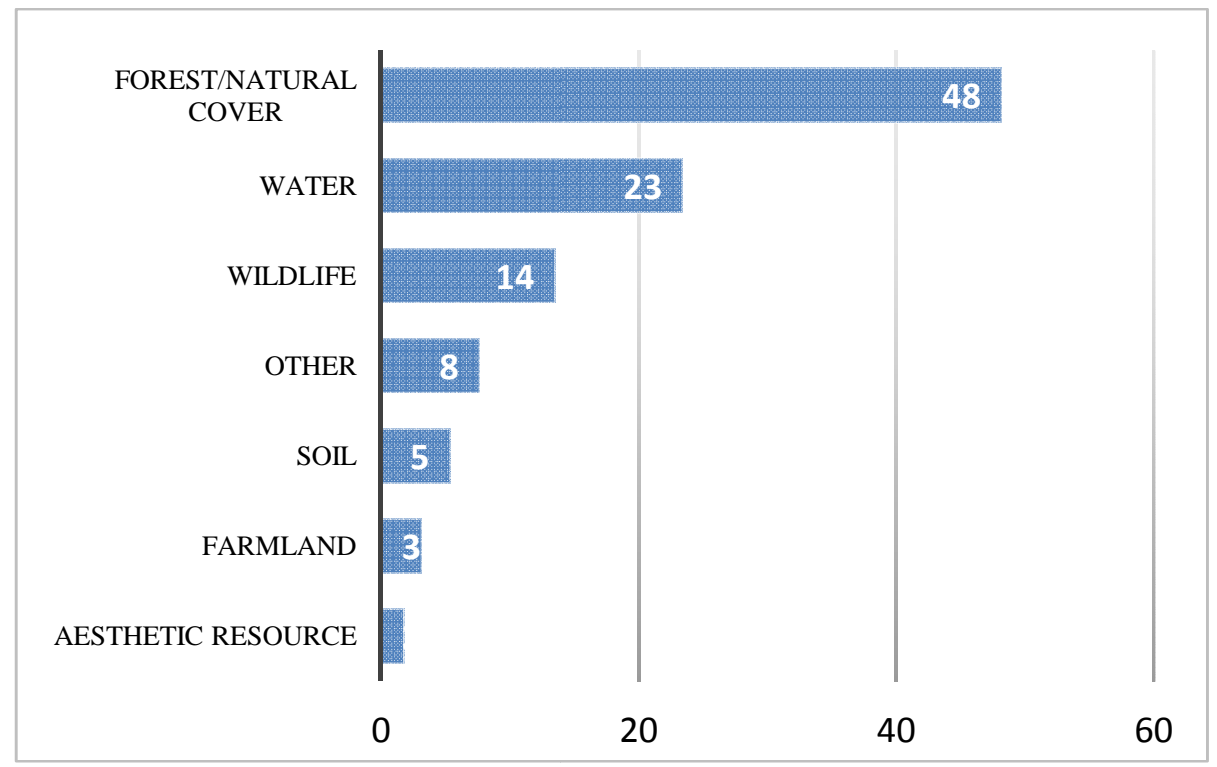

Figure 10: Percentage of responses by theme used to group "natural resource to protect" 
Due to the broad array of responses about the "main threats to forestland" data was organized in themes and sub themes, and to highlight the situation in each region results are presented by county. Overall main threat identified by respondents was "human influence" (57\%), followed by biological agents (35\%).

Table 4. Main threats to forestland

\begin{tabular}{|c|c|c|c|}
\hline & \multicolumn{3}{|c|}{ Themes } \\
\hline 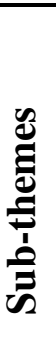 & $\begin{array}{l}\text { Human } \\
\text { Development } \\
\text { Humans } \\
\text { Pollution } \\
\text { Mineral E\&E } \\
\text { Forest mgt. } \\
\text { practices }\end{array}$ & $\begin{array}{l}\text { Biological } \\
\text { Pests } \\
\text { Disease }\end{array}$ & $\begin{array}{l}\text { Environmental } \\
\text { Fire } \\
\text { Weather } \\
\text { Land slips }\end{array}$ \\
\hline
\end{tabular}

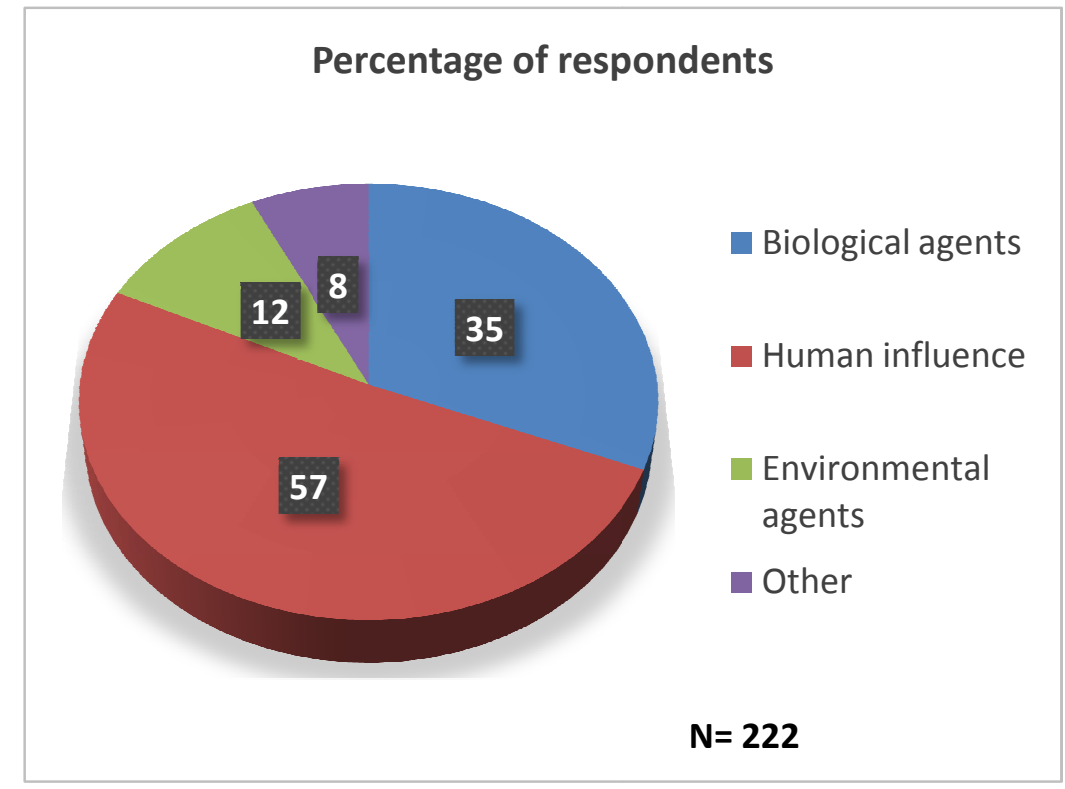

Figure 11: Themes and percent of responses for "main threats" to forestland

Concerns about main threats varied by county (region), this was expected considering the particular situation in each county. In the case of Berkeley and Jefferson main threats identified were 
development (38\% Jefferson, 42\% Berkeley), and pest (49\% Jefferson, 36\% Berkeley). Main concerns of respondents from Marion, Marshall, and Ritchie counties were related to mining/gas and oil activities, with a 60\% in Marshall, $40 \%$ in Ritchie and 28\% in Marion; although the biggest concern of respondents from Marion as well as Cabell was related to pest (34\% Marion, 31\% Cabell).
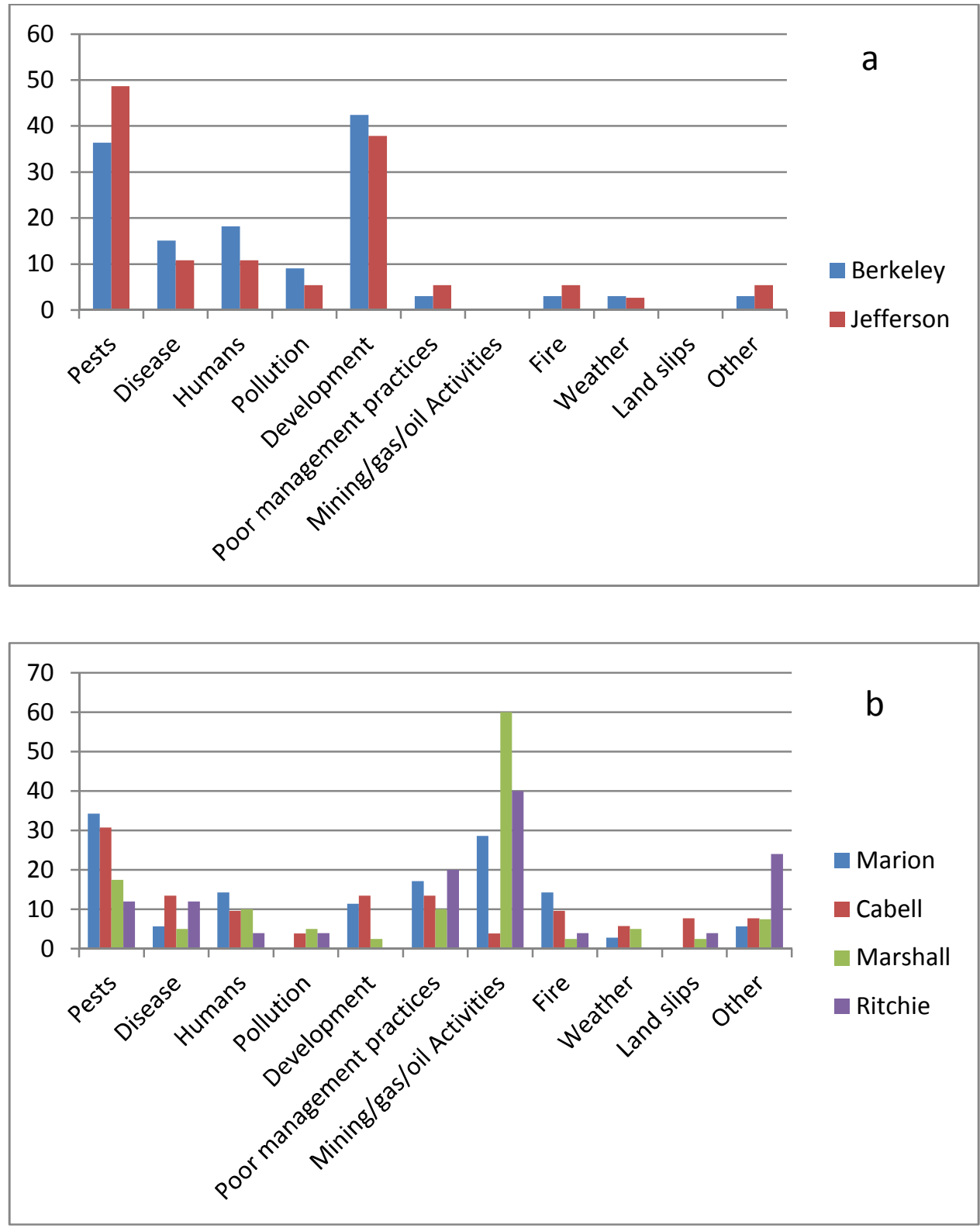

Figure 12(a-b): Themes and percent of responses for "main threats" to forestland by county 
Respondents were given the opportunity of provide three top reasons to own their property and the "Recreational" reason ranked highest with a $21 \%$, followed by "Sentimental" with $16 \%$, being "Conservation of biological attributes" the lowest with $6 \%$.

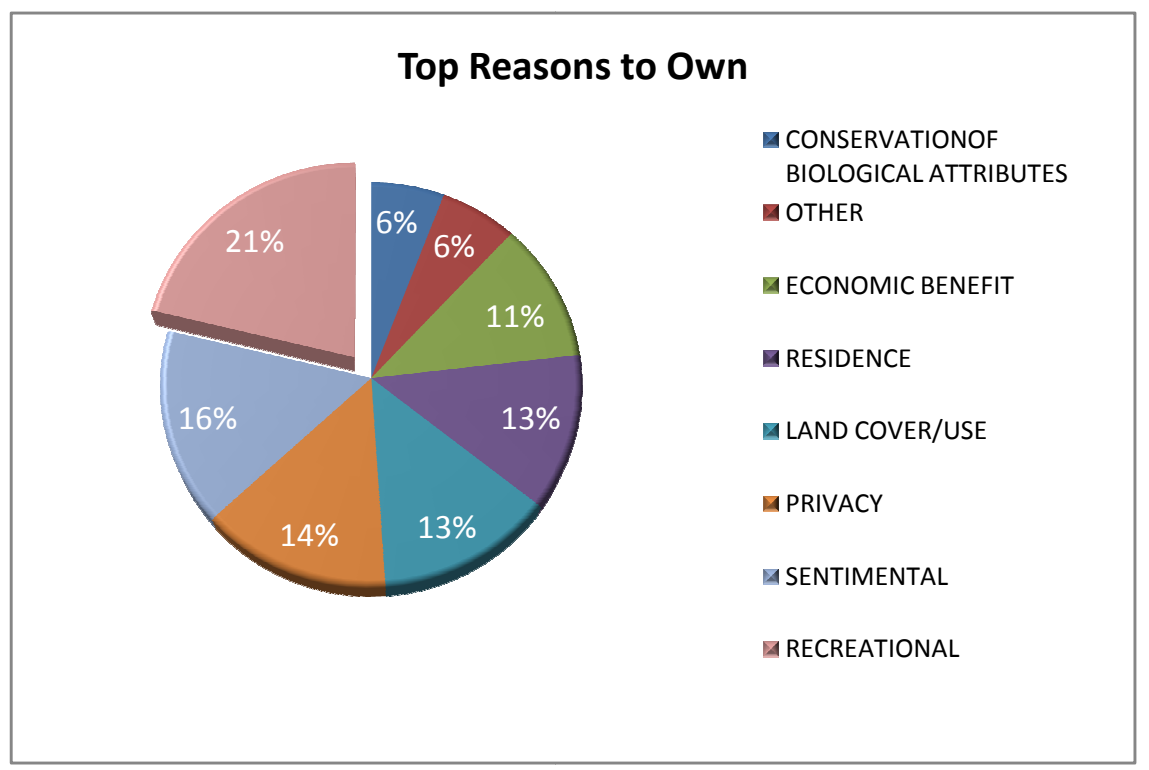

Figure 13: Percent responses for top reasons to own by descriptor type

Table 5. Top Reasons to own descriptions by theme

\begin{tabular}{|c|c|c|c|c|c|}
\hline $\begin{array}{l}\text { Economic } \\
\text { Benefit }\end{array}$ & $\begin{array}{l}\text { Land } \\
\text { Cover/Use }\end{array}$ & $\begin{array}{l}\text { Conservation } \\
\text { Of Biological } \\
\text { Attributes }\end{array}$ & Residence & Sentimental & Recreational \\
\hline Less taxes & $\begin{array}{l}\text { Woods/lan } \\
\text { d }\end{array}$ & $\begin{array}{l}\text { Preservation of } \\
\text { wildlife }\end{array}$ & $\begin{array}{l}\text { Wanting to } \\
\text { live in the } \\
\text { country }\end{array}$ & $\begin{array}{l}\text { Inherited(fam } \\
\text { ily) from } \\
\text { parents(sister, } \\
\text { brother and I) }\end{array}$ & $\begin{array}{l}\text { I like to be } \\
\text { surrounded } \\
\text { by wildlife }\end{array}$ \\
\hline $\begin{array}{l}\text { It's the best } \\
\text { investment I } \\
\text { can make }\end{array}$ & Farming & $\begin{array}{l}\text { I want to sustain } \\
\text { woodlands }\end{array}$ & $\begin{array}{l}\text { Principal } \\
\text { residence }\end{array}$ & $\begin{array}{l}\text { Gift from } \\
\text { parents }\end{array}$ & $\begin{array}{l}\text { Forest } \\
\text { recreative use }\end{array}$ \\
\hline $\begin{array}{l}\text { Income we } \\
\text { harvest every } \\
20 \text { years- } \\
\text { trees }\end{array}$ & $\begin{array}{l}\text { gardening } \\
\text { activities }\end{array}$ & $\begin{array}{l}\text { Protect enhance } \\
\text { environment }\end{array}$ & To live on it & $\begin{array}{l}\text { Belonged to } \\
\text { my father }\end{array}$ & $\begin{array}{l}\text { Enjoy natural } \\
\text { surroundings }\end{array}$ \\
\hline $\begin{array}{l}\text { Buildable } \\
\text { property }\end{array}$ & $\begin{array}{l}\text { Christmas } \\
\text { trees }\end{array}$ & $\begin{array}{l}\text { Wildlife } \\
\text { management and } \\
\text { hunting }\end{array}$ & $\begin{array}{l}\text { Love to live } \\
\text { in the country }\end{array}$ & $\begin{array}{l}\text { Has been in } \\
\text { my family for } \\
6 \text { generations }\end{array}$ & Hunting \\
\hline
\end{tabular}




\section{Benefits of Participating in Natural Resources Organizations}

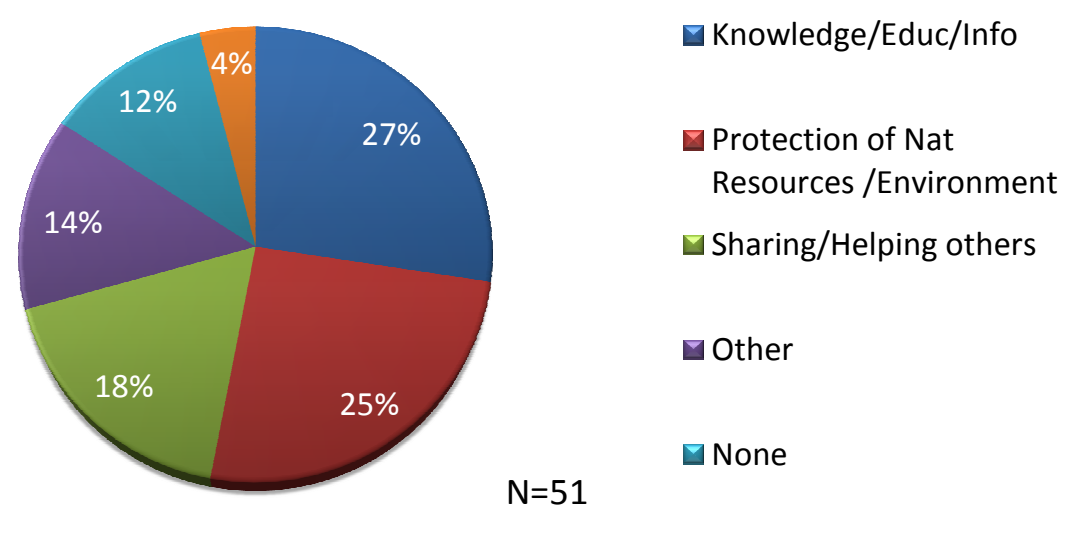

Figure 14: Percentage of PF owners according to their reasons to participating in natural resources organizations

\section{Variable reduction process}

Similar to previous work by Finley et al. (2006), a high degree of correlation was found among responses in the three themed groups of the questionnaire-reasons for owning woodland property, attitudes and actions of woodland owners, and barriers to cross-boundary cooperation. In this study, variables from these three groups are used as explanatory variables to explore associations with woodland owner's willingness to participate in cross boundary cooperation. In addition, correlation among the items of suggested cooperatives activities--the items intended for use as response variables--was found and suggested evaluation of whether these items could be reduced to a lower number of variables.

Reasons for owning woodland property

The ten variables used to measure reasons woodland owners own property (Q18a-Q18j, Appendix D) were significantly correlated with 4 variables having 5 statistically significant correlations when the variable WATER was included. The variable WATER was not present in Finley et al. (2006) study and will not be included in this part of the analysis; however this was 
included in the questionnaire as an issue associated with land use (McKinney, Scarlett and Kemmis, 2010). Factor loading for WATER was low (0.498) when included in the analysis. Spearman's rank test was used to determine the strength of association among all the variables. Three variables were associated with four others (WILDHABIT, REMAINAT, and PRIVACY). The degree of association was moderate ( $>0.30$ but below 0.60$)$ for almost all the variables, with only a few obtaining values above 0.70 . Only correlation values $>0.30$ were considered large enough to be important. Statistically significant correlation below this has been considered too weak to warrant the search for underlying factors (Hair et al., 1998). Components one to three (Table 6) have the highest eigenvalues indicating the amount of variance accounted by these components.

Table 6. Eigen values and amount of variation in reasons to own forest explained by 9 variables.

\begin{tabular}{crrrr}
\hline Component & Eigenvalue & Difference & Proportion & Cumulative \\
& & & & \\
\hline $\mathbf{1}$ & 3.04362 & 1.37011 & 0.3382 & 0.3382 \\
$\mathbf{2}$ & 1.67352 & 0.28503 & 0.1859 & 0.5241 \\
$\mathbf{3}$ & 1.38848 & 0.52885 & 0.1543 & 0.6784 \\
$\mathbf{4}$ & 0.85964 & 0.28596 & 0.0955 & 0.7739 \\
$\mathbf{5}$ & 0.57367 & 0.03159 & 0.0637 & 0.8377 \\
$\mathbf{6}$ & 0.54209 & 0.20024 & 0.0602 & 0.8979 \\
$\mathbf{7}$ & 0.34185 & 0.02014 & 0.038 & 0.9359 \\
$\mathbf{8}$ & 0.32171 & 0.06631 & 0.0357 & 0.9716 \\
$\mathbf{9}$ & 0.25541 & & 0.0284 & \\
\hline
\end{tabular}

The PCA using a Varimax rotation method produced three principal components (Table 7) leaving the variable FAMILY to stand by itself (factor loading <0.50). Cronbach's Alpha was generated for variables that grouped on a given component to check the internal consistency (the degree to which a set of items is explained by a single latent factor or in this case, component). As a rule of thumb those factors where the coefficient of consistency was 0.70 or greater were kept (Hair et al., 1998). 
Parallel analysis confirmed the reduction of variables obtained in the process. The three components account for $68 \%$ of the variation among the nine survey items.

Variable grouping obtained was the same as Finley but the names of some composite variables (PCs) changed. When naming the PCs we looked at those with the higher loadings to name the variables after them (Hair et al., 1998). In this study the items "wildlife habitat" and "personal recreation" had higher loadings but we decided to assign the name "NATURE" to the first to better reflect the variables within the PC.

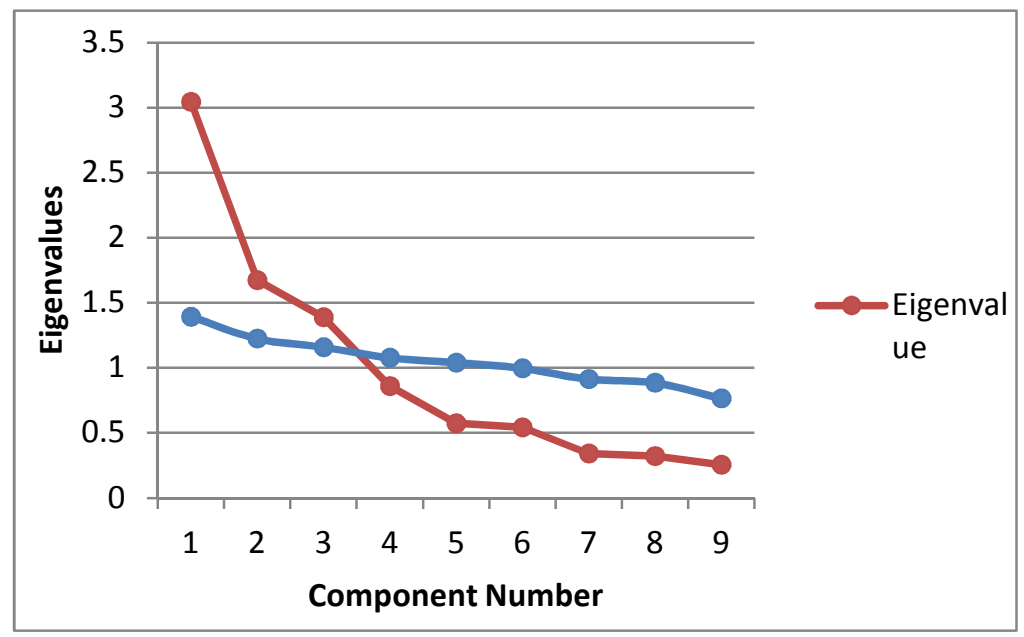

Figure 15: Parallel analysis with Eigen values generated from reasons to own data compared with 95th percentile Eigen values from simulated random populations.

Table 7. Factor structure for PCA with Varimax rotation related to reasons to own. Bold loading of variables on factors indicate most significant for given variable.

\begin{tabular}{llll}
\hline & Factor1 & Factor2 & Factor3 \\
\hline ENVIRONM & $\mathbf{0 . 8 5 7 2 4}$ & & \\
WILDHABIT & $\mathbf{0 . 8 7 2 7 8}$ & & \\
REMAINAT & $\mathbf{0 . 8 6 6 7 4}$ & & \\
PRIVACY & & $\mathbf{0 . 8 2 1 7 9}$ & \\
RECREATION & & $\mathbf{0 . 8 6 6 7 8}$ & \\
RURALIFE & & $\mathbf{0 . 7 9 5 5}$ & \\
REALESTATE & & & $\mathbf{0 . 8 0 9 4}$ \\
TIMBER & & & $\mathbf{0 . 8 4 0 0 9}$ \\
FAMILY & & & 0.40401 \\
\hline
\end{tabular}


Table 8. Survey items related to reasons for owning property and descriptive statistics for principal components analysis.

\begin{tabular}{|c|c|c|c|c|c|c|}
\hline $\begin{array}{l}\text { Description of reason for } \\
\text { owning property }\end{array}$ & Mean (SD) & $\begin{array}{c}\mathrm{PC}^{1} \\
\text { Loadings }\end{array}$ & $\mathbf{P C}^{2} \#$ & $\alpha$ & This study & $\begin{array}{l}\text { Finley et } \\
\text { al. (2006) }\end{array}$ \\
\hline & & & & & $\mathrm{PC}$ & $\mathrm{PC}$ \\
\hline -...to protect the environment & $1.89(0.95)$ & 0.857 & 1 & 0.84 & NATURE & Environ \\
\hline -...to provide wildlife habitat & $1.66(0.86)$ & 0.873 & 1 & & (Wildhab) & \\
\hline -...to ensure it remains natural & $1.69(0.83)$ & 0.867 & 1 & & & \\
\hline -...for the feeling of privacy & $1.40(0.72)$ & 0.822 & 2 & 0.81 & RECREATION & Rural \\
\hline -...for personal recreation & $1.48(0.79)$ & 0.867 & 2 & & & Life \\
\hline $\begin{array}{l}-\ldots \text { because I value a rural life } \\
\text { style }\end{array}$ & $1.43(0.75)$ & 0.796 & 2 & & & \\
\hline$-\ldots$ as a real estate investment & $2.66(1.32)$ & 0.809 & 3 & $0.59^{3}$ & $\begin{array}{l}\text { REAL } \\
\text { ESTATE } \\
\text { (Develop) }\end{array}$ & Develop \\
\hline -...for income from timber & $3.13(1.30)$ & 0.840 & 3 & & TIMBER & Timber \\
\hline $\begin{array}{l}\text {-...to preserve family and } \\
\text { tradition }\end{array}$ & $1.77(1.08)$ & 0.404 & & & TRADITION & Tradition \\
\hline
\end{tabular}

Likert scale items used here: 1=Very important, $2=$ Moderately important, $3=$ Neutral, 4= Low importance, $5=$ Not at all important.

${ }^{1}$ Principal Component criteria for selection set at a minimum of 0.50

${ }^{2}$ Principal Component numbers from Varimax rotation . ${ }^{3}$ Cronbach's alpha values, selection criteria set at a minimum of 0.70 , survey items with lower values are left to stand alone

\section{Attitudes and actions of woodland owners}

Eighteen items were used to assess attitudes of woodland owners towards various crossboundary issues (Q17a- Q17p, and Q19a- Q19b, Appendix D). Spearman correlations generated between all pairwise combinations of these 18 variables showed a high degree of association among the variables. Two variables were associated with four other variables at the $\mathrm{p}<0.05$ level, however all other variables had higher numbers of associations. One variable (THERAP) had significant associations with 13 others. Seventeen variables of interest had from 1 to 5 statistically significant correlations $(\mathrm{p}<0.05$; median $=3)$. This high level of correlations suggests that these items could be representing similar underlying traits (constructs) and warrants a 
variable reduction assessment. The significant and complex correlations were expected given findings from Finley et al. (2006).

Table 9. Eigen values and amount of variation explained in cross-boundary attitudes by 18 variables

\begin{tabular}{crrrr}
\hline Component & Eigenvalue & Difference & Proportion & Cumulative \\
$\mathbf{1}$ & 3.9213 & 1.6975 & 0.2178 & 0.2178 \\
$\mathbf{2}$ & 2.2238 & 0.2313 & 0.1235 & 0.3414 \\
$\mathbf{3}$ & 1.9925 & 0.5036 & 0.1107 & 0.4521 \\
$\mathbf{4}$ & 1.4890 & 0.3085 & 0.0827 & 0.5348 \\
$\mathbf{5}$ & 1.1804 & 0.1428 & 0.0656 & 0.6004 \\
$\mathbf{6}$ & 1.0376 & 0.1122 & 0.0576 & 0.6580 \\
$\mathbf{7}$ & 0.9255 & 0.1920 & 0.0514 & 0.7095 \\
$\mathbf{8}$ & 0.7335 & 0.0507 & 0.0408 & 0.7502 \\
$\mathbf{9}$ & 0.6828 & 0.0523 & 0.0379 & 0.7881 \\
$\mathbf{1 0}$ & 0.6305 & 0.0677 & 0.035 & 0.8232 \\
$\mathbf{1 1}$ & 0.5628 & 0.0716 & 0.0313 & 0.8544 \\
$\mathbf{1 2}$ & 0.4912 & 0.0236 & 0.0273 & 0.8817 \\
$\mathbf{1 3}$ & 0.4676 & 0.0463 & 0.026 & 0.9077 \\
$\mathbf{1 4}$ & 0.4213 & 0.0466 & 0.0234 & 0.9311 \\
$\mathbf{1 5}$ & 0.3747 & 0.0303 & 0.0208 & 0.9519 \\
$\mathbf{1 6}$ & 0.3444 & 0.0593 & 0.0191 & 0.9711 \\
$\mathbf{1 7}$ & 0.2851 & 0.0492 & 0.0158 & 0.9869 \\
$\mathbf{1 8}$ & 0.2359 & & 0.0131 & 1 \\
\hline
\end{tabular}




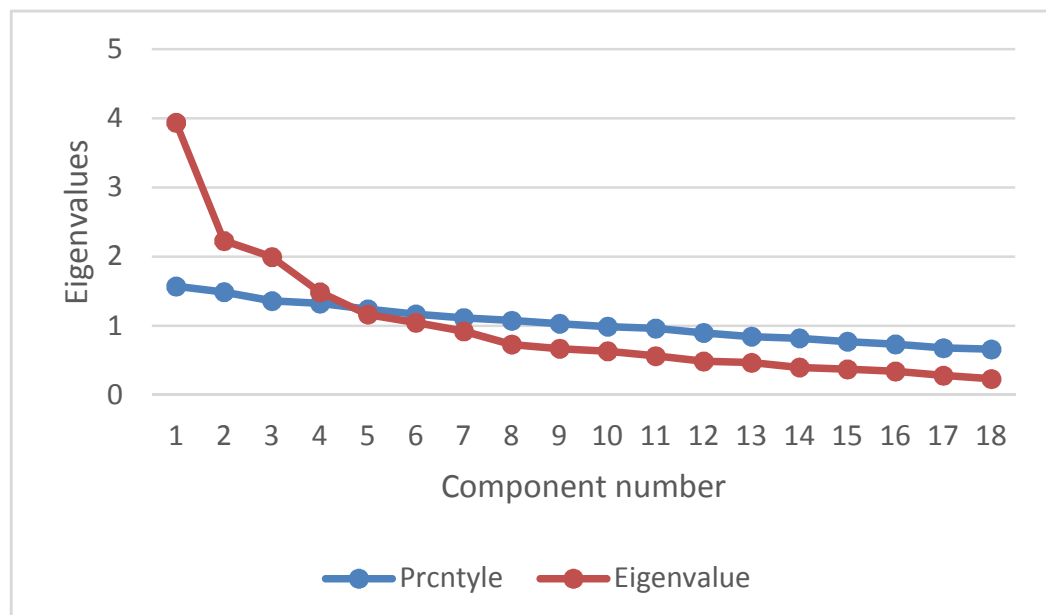

Figure 16: Parallel analysis with Eigen values generated from cross-boundary data compared with 95th percentile Eigen values from simulated random populations.

According to the parallel analysis (PA), four is an appropriate number of factors for these data.

These four components explain 53\% of the variation among the fourteen cross-boundary items.

Table 10. Factor structure for PCA with Varimax rotation. Bold loading of variables on factors indicate most significant for given variable.

\begin{tabular}{lllll}
\hline & Factor1 & Factor2 & Factor3 & Factor4 \\
\hline STEWARD & $\mathbf{0 . 7 6 2 9 3}$ & & & \\
OWESOCIETY & $\mathbf{0 . 6 9 3 9 3}$ & & & \\
PROTWILD & $\mathbf{0 . 5 6 7 7 1}$ & & & \\
THERAP & $\mathbf{0 . 7 1 6 4 2}$ & & & \\
IMPROVELAND & $\mathbf{0 . 7 5 3 0 2}$ & & & \\
TIMENJOY & $\mathbf{0 . 7 0 0 9 5}$ & & $\mathbf{0 . 7 5 7 1 2}$ & \\
DEVWELL & & & $\mathbf{0 . 7 4 5 3 6}$ & \\
COMMUNNITY & & & $\mathbf{0 . 5 2 1 8 9}$ & \\
ORGEFFORT & 0.35348 & & $\mathbf{0 . 8 6 3 2 1}$ & \\
THREAT & & & & \\
OBJECTIVES & & $\mathbf{0 . 7 5 5 1 1}$ & & \\
COMPATOBJ & & $\mathbf{0 . 7 6 9 6 8}$ & & $\mathbf{0 . 7 6 9 0 3}$ \\
SENSECOMMU & & $\mathbf{0 . 7 8 2 2 2}$ & & $\mathbf{0 . 7 4 9 4 3}$ \\
ENJOY & & & & $\mathbf{0 . 6 0 3 0 8}$ \\
TRAIL & & & & \\
FEWER & & & & \\
ECOHEALTH & 0.36496 & & & \\
COMMUNIC & & -0.6081 & & \\
\hline
\end{tabular}


Table 11. Survey items assessing attitudes and actions associated with cross-boundary cooperation and descriptive statistics for principal components analysis.

\begin{tabular}{|c|c|c|c|c|c|}
\hline Description of Survey Items & Mean (sd) & $\begin{array}{c}\mathbf{P C}^{1} \\
\text { Loading }\end{array}$ & $\begin{array}{l}\mathbf{P C} \\
\#^{2}\end{array}$ & $\begin{array}{l}\text { This study- } \\
-\alpha^{3}- \\
\text { PC }\end{array}$ & $\begin{array}{c}\text { Finley et al. } \\
2006 \\
--\alpha^{3}- \\
\text { PC }\end{array}$ \\
\hline I feel an obligation to future generations to be & $1.33(0.61)$ & 0.76 & 1 & $\begin{array}{c}0.80 \\
\text { STEWARD }\end{array}$ & $\begin{array}{c}0.73 \\
\text { STEWARD }\end{array}$ \\
\hline $\begin{array}{l}\text { We as a society owe it to the environment to } \\
\text { be good stewards of the land. }\end{array}$ & $1.38(0.71)$ & 0.69 & 1 & & \\
\hline $\begin{array}{l}\text { It is up to me as a landowner to protect } \\
\text { wildlife habitat and biodiversity. }\end{array}$ & $1.55(0.74)$ & 0.57 & 1 & & \\
\hline $\begin{array}{l}\text { I find it therapeutic or enjoyable doing things } \\
\text { to improve my forestland. }\end{array}$ & $1.78(0.84)$ & 0.72 & 1 & & $\begin{array}{l}0.82 \\
\text { IMPROVE }\end{array}$ \\
\hline $\begin{array}{l}\text { I feel great satisfaction when I do things to } \\
\text { improve my land. }\end{array}$ & $1.56(0.72)$ & 0.75 & 1 & & LAND \\
\hline $\begin{array}{l}\text { I would like to spend more time enjoying my } \\
\text { land. }\end{array}$ & $1.51(0.72)$ & 0.70 & 1 & & \\
\hline I know my neighbors' forestland objectives. & $3.42(1.09)$ & 0.76 & 2 & 0.74 & 0.74 \\
\hline $\begin{array}{l}\text { I feel that my neighbors' forestland objectives } \\
\text { are compatible with my own. }\end{array}$ & $2.90(0.91)$ & 0.77 & 2 & $\begin{array}{l}\text { SENSE } \\
\text { COMM }\end{array}$ & $\begin{array}{l}\text { SENSE } \\
\text { COMM }\end{array}$ \\
\hline $\begin{array}{l}\text { I feel a sense of community with my } \\
\text { forestland neighborhood. }\end{array}$ & $2.87(0.98)$ & 0.78 & 2 & & \\
\hline I welcome more development in my tow & $2.89(1.27)$ & 0.76 & 3 & 0.7 & 0.74 \\
\hline $\begin{array}{l}\text { Housing development in my area will } \\
\text { decrease the sense of community. }\end{array}$ & $2.57(1.20)$ & 0.75 & 3 & DEVWELL & DEVWELL \\
\hline $\begin{array}{l}\text { It will take an organized effort among } \\
\text { community members to protect forestland } \\
\text { from development. }\end{array}$ & $2.17(1.00)$ & 0.52 & 3 & & \\
\hline $\begin{array}{l}\text { I view development as a threat to things I } \\
\text { value. }\end{array}$ & $2.37(1.15)$ & 0.86 & 3 & & \\
\hline $\begin{array}{l}\text { I wish my neighbors would enjoy my land } \\
\text { more. }\end{array}$ & $3.63(1.09)$ & 0.77 & 4 & $\begin{array}{l}0.56 \\
\text { SHARE }\end{array}$ & $\begin{array}{l}0.56 \\
\text { SHARE }\end{array}$ \\
\hline $\begin{array}{l}\text { I would allow my neighbors to build a trail } \\
\text { across my land if I could control the type of } \\
\text { recreation that occurs on it. }\end{array}$ & $4.04(1.21)$ & 0.75 & 4 & & \\
\hline The fewer people on my land the better.* & $3.86(1.22)$ & 0.60 & 4 & & \\
\hline $\begin{array}{l}\text { Do you consider the ecological health of } \\
\text { neighboring or nearby properties when } \\
\text { making decisions concerning your } \\
\text { forestland** }\end{array}$ & $2.86(0.99)$ & -0.36 & & $\begin{array}{l}\text { ECO } \\
\text { HEALTH }\end{array}$ & $\begin{array}{l}\text { ECO } \\
\text { HEALTH }\end{array}$ \\
\hline $\begin{array}{l}\text { Have your neighbors or owners of nearby } \\
\text { properties spoken to you about their } \\
\text { management decisions** }\end{array}$ & $1.50(0.82)$ & -0.61 & & COMMUNIC & COMMUNIC \\
\hline
\end{tabular}

Likert scale used: $1=$ Strongly agree $.2=$ Somewhat agree, $3=$ Neutral,, $4=$,Somewhat disagree, $5=$ Strongly disagree

$*$ Likert scale reversed for these items.

** Scale used: $1=$ Never, $2=$ Rarely, $3=$ Sometimes, $4=$ Often, no reversion was done in this items.

${ }^{1}$ Principal Component. ${ }^{2}$ Principal Component \# from Varimax rotation. ${ }^{3}$ Cronbach's alpha values set at minimum of 0.70 
Mean values obtained in the $\mathrm{PC}$ variables indicate a positive agreement for the items included in the STEWARD component (mean values between 1.33 and 1.78) and generally less agreement for the rest of the items associated with other components (mean values 2.17 to 4.04 ). The survey items included in the variable SHARE gave mean values between 3.63 and 4.04 indicating disagreement toward the idea of sharing their properties. In the case of the variables ECOHEALTH and COMMUNIC mean values are low (1.5 and 2.86)) indicating low consideration about ecological health of neighboring properties and scarce communication regarding management issues.

\section{Barriers to cross-boundary cooperation}

Nine variables were used to measure barriers to cross-boundary cooperation. Six variables had six statistically significant correlations with other variables. To match the study of Finley et al. (2006), the variable "interested in cooperation" (Q17r, Appendix D) was excluded in the majority of the results and is only present at Table 14 .

Table 12. Eigen values and amount of variation explained in barriers to collaboration by eight variables

\begin{tabular}{crrrr}
\hline Component & Eigenvalue & Difference & Proportion & Cumulative \\
& & & & \\
\hline $\mathbf{1}$ & 3.87135 & 2.81324 & 0.48390 & 0.48390 \\
$\mathbf{2}$ & 1.05811 & 0.19424 & 0.13230 & 0.61620 \\
$\mathbf{3}$ & 0.86387 & 0.23699 & 0.10800 & 0.72420 \\
$\mathbf{4}$ & 0.62688 & 0.10041 & 0.07840 & 0.80250 \\
$\mathbf{5}$ & 0.52647 & 0.04987 & 0.06580 & 0.86830 \\
$\mathbf{6}$ & 0.47660 & 0.15550 & 0.05960 & 0.92790 \\
$\mathbf{7}$ & 0.32110 & 0.06547 & 0.04010 & 0.96800 \\
$\mathbf{8}$ & 0.25562 & & 0.03200 & 1.00000 \\
\hline
\end{tabular}


Parallel analysis (PA) gave evidence of a single significant component. The single component explains $48 \%$ of the variation among the eight barriers to cross-boundary items. Two variables were left to stand by themselves (DISAGREEUSE and UNKNOWNEIGHB).

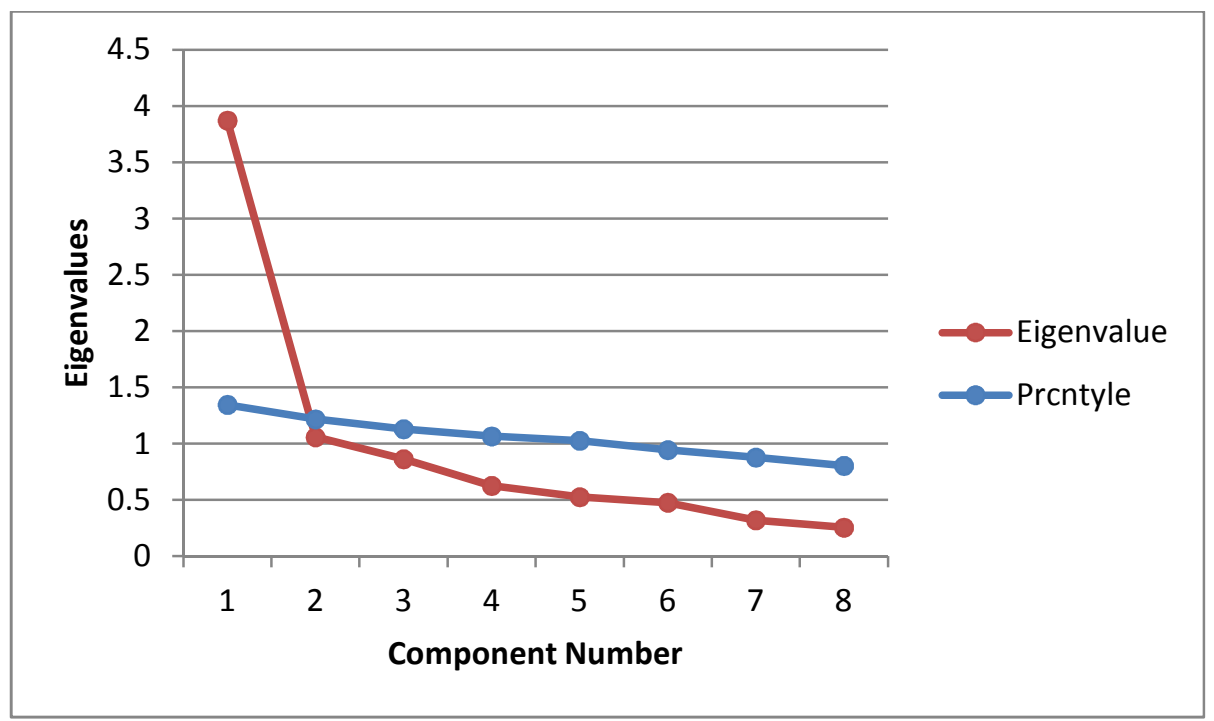

Figure 17: Parallel analysis with Eigen values generated from barriers to collaboration data compared with 95th percentile Eigen values from simulated random populations.

Table 13. Factor structure for PCA with Varimax rotation. Bold loading of variables on factors indicate most significant for given variable.

\begin{tabular}{lcr}
\hline & Factor1 & Factor2 \\
\hline OVERCOMMITED & $\mathbf{0 . 6 7 1 3 1}$ & \\
SATISFIED & $\mathbf{0 . 7 7 2 4 9}$ & \\
NOBENEFIT & $\mathbf{0 . 8 4 8 3 1}$ & \\
INFRINGEPRIV & $\mathbf{0 . 7 5 1 0 3}$ & \\
TIMECONSUM & $\mathbf{0 . 8 0 0 2 3}$ & \\
KNOWBETTER & $\mathbf{0 . 5 7 7 2 9}$ & \\
DISAGREEUSE & & $\mathbf{0 . 9 0 7 4 3}$ \\
UNKNOWNEIGHB & & $\mathbf{0 . 5 8 9 7 8}$ \\
\hline
\end{tabular}


Table 14: Survey items assessing barriers to cross-boundary cooperation and descriptive statistics for principal components analysis.

\begin{tabular}{|c|c|c|c|c|c|}
\hline Description of Survey Items & $\begin{array}{l}\text { Mean } \\
\text { (SD) }\end{array}$ & $\begin{array}{l}\text { PC } \\
\text { Loadings }^{1}\end{array}$ & $\begin{array}{c}\mathbf{P C} \\
\#^{2}\end{array}$ & $\begin{array}{c}\text { This Study } \\
--\alpha- \\
\text { PC }\end{array}$ & $\begin{array}{c}\text { Finley et al. } \\
\text { (2006) } \\
\text { PC }\end{array}$ \\
\hline $\begin{array}{l}\text { I do not agree with the way my } \\
\text { neighbors use their forestland. }\end{array}$ & $\begin{array}{l}3.09 \\
(0.92)\end{array}$ & 0.91 & 2 & \begin{tabular}{l}
\multicolumn{1}{c}{$0.46^{3}$} \\
DISAGREE \\
USE
\end{tabular} & Disagree Use \\
\hline $\begin{array}{l}\text { I would not cooperate because I } \\
\text { do not know many of my } \\
\text { neighbors }\end{array}$ & $\begin{array}{l}3.35 \\
(1.07)\end{array}$ & 0.59 & 2 & $\begin{array}{l}0.46^{3} \\
\text { UNKNOW } \\
\text { NEIGHB }\end{array}$ & $\begin{array}{l}\text { Unknow } \\
\text { neighb }\end{array}$ \\
\hline $\begin{array}{l}\text { I would not cooperate with my } \\
\text { neighbors because I have too } \\
\text { many other commitments in my } \\
\text { life. }\end{array}$ & $\begin{array}{l}3.21 \\
(1.03)\end{array}$ & 0.67 & 1 & $\begin{array}{l}0.89 \\
\text { NOCOOP } \\
\text { BEN }\end{array}$ & $\begin{array}{l}\text { Overcom } \\
\text { mitted }\end{array}$ \\
\hline $\begin{array}{l}\text { I would not cooperate because I } \\
\text { am satisfied with the way things } \\
\text { are. }\end{array}$ & $\begin{array}{l}3.00 \\
(1.07)\end{array}$ & 0.77 & 1 & & $\begin{array}{l}\text { Satisfied } \\
\text { with situation }\end{array}$ \\
\hline $\begin{array}{l}\text { I would not cooperate because I } \\
\text { do not see any benefits from } \\
\text { cooperation with my neighbors. }\end{array}$ & $\begin{array}{l}3.22 \\
(1.10)\end{array}$ & 0.85 & 1 & & $\begin{array}{l}\text { No Coop } \\
\text { Benefits }\end{array}$ \\
\hline $\begin{array}{l}\text { Cooperation with my neighbors } \\
\text { could infringe on my privacy. }\end{array}$ & $\begin{array}{l}2.91 \\
(1.17)\end{array}$ & 0.75 & 1 & & Privacy \\
\hline $\begin{array}{l}\text { Cooperation would be too time } \\
\text { consuming. }\end{array}$ & $\begin{array}{l}3.05 \\
(1.03)\end{array}$ & 0.80 & 1 & & Time \\
\hline $\begin{array}{l}\text { I would like to get to know my } \\
\text { neighbors better.* }\end{array}$ & $\begin{array}{l}3.21 \\
(0.91)\end{array}$ & 0.58 & 1 & & $\begin{array}{l}\text { Avoid } \\
\text { neighbors }\end{array}$ \\
\hline $\begin{array}{l}\text { I would be interested in } \\
\text { cooperating with my neighbors } \\
\text { on forest management/ } \\
\text { conservation initiatives.** }\end{array}$ & $\begin{array}{l}3.34 \\
(1.07)\end{array}$ & 0.80 & 1 & & \\
\hline
\end{tabular}

Likert scale used: $1=$ Strongly agree. $2=$ Somewhat agree, $3=$ Neutral, $4=$ Somewhat disagree, $5=$ Strongly disagree. *Scale reversed for this item

** When this positive item is introduced Crombach's alpha is 0.87 for PC \# 1

${ }^{1}$ Principal Component criteria for selection set at a minimum of 0.50

${ }^{2}$ Principal Component numbers from Varimax rotation

${ }^{3}$ Cronbach's alpha values, selection criteria set at a minimum of 0.70 ,

Mean values obtained from seven survey items grouped in PC variable NOBENEFIT range between 2.91 to 3.34 . Given that this value represents a negative statement, the disagreement indicates a favorable attitude towards cooperative interactions. In the case of the PC variables DISAGREEUSE and UNKNOWNEIGHB the trend is also positive towards cooperative 
activities (mean 3.09 and 3.35) as the items making up these components are also negative statements.

\section{Suggested cooperative activities}

The interest of respondents in suggested cooperative activities (CAs) was measured using 10 survey items. Results were similar to those obtained by Finley et al. (2006), with mean values from 3 to 4.39 (2.83-4.37 for Finley). Two PC variables were obtained from the analysis (Table 15). Variables obtained from the reduction of proposed cooperative actions ("Walking tour" and "Jointly market") from now on will be called "CAmgt" and "CAdev" which represent cooperative activities related to management and cooperative activities related to development, respectively. In the case of the dependent variables CAmgt and CAdev mean values obtained range from 3.0 to 3.83 , for the first and from 3.42 to 4.39 for the second. Considering the scale the trend observed is toward "uninterested."

As a result of the variable reduction the initial 48 variable items used for the analysis were reduced to $16 \mathrm{PC}$ variables (Table 16). These variables represent reasons, attitudes and beliefs depending on the group from which they were obtained.

The CAs variables obtained from the PCA were used as response binary variables to assess willingness to participate using logistic regression analysis. All variables having and ordinal scale were converted to binary. The variable STEWARD was not included in the analysis because of its poor contribution as a predictor. Variables with statistically significant results (bold values) in relation to CAmgt and CAdev are presented in Table 17 and 18. 
Table 15. Survey items of suggested Cooperative Activities and descriptive statistics for principal components analysis

\begin{tabular}{|c|c|c|c|c|c|}
\hline Description of Survey Items* & $\begin{array}{c}\text { Mean } \\
\text { (SD) }\end{array}$ & $\begin{array}{l}\mathrm{PC}^{1} \\
\text { Loadings }\end{array}$ & $\begin{array}{l}\mathbf{P C} \\
\#^{2} \\
\end{array}$ & $\begin{array}{c}\text { Conbrach' } \\
\text { s-- } \alpha--{ }^{3}\end{array}$ & $\begin{array}{c}\text { Variables } \\
(\mathrm{PC})\end{array}$ \\
\hline $\begin{array}{l}\text {-In the future, would you be interested in } \\
\text { attending a series of meetings on forest } \\
\text { management with your neighbors? }\end{array}$ & $\begin{array}{c}3.26 \\
(1.33)\end{array}$ & 0.77 & 1 & 0.91 & $\begin{array}{l}\text { Walking } \\
\text { tour } \\
\text { (CAmg) }\end{array}$ \\
\hline $\begin{array}{l}\text {-In the future, would you be interested in } \\
\text { joining your neighbors for a walking } \\
\text { tour of your collective properties? }\end{array}$ & $\begin{array}{c}3.40 \\
(1.38)\end{array}$ & 0.83 & 1 & & \\
\hline $\begin{array}{l}\text {-In the future, would you be interested in } \\
\text { talking with your neighbors about } \\
\text { managing wildlife habitat together? }\end{array}$ & $\begin{array}{c}3.0 \\
(1.34)\end{array}$ & 0.82 & 1 & & \\
\hline $\begin{array}{l}\text {-In the future, would you be interested in } \\
\text { sharing the fee for hiring a forester to } \\
\text { write a management plan with your } \\
\text { neighbors? }\end{array}$ & $\begin{array}{c}3.83 \\
(1.18)\end{array}$ & 0.76 & 1 & & \\
\hline $\begin{array}{l}\text {-In the future, would you be interested in } \\
\text { sharing forest management equipment } \\
\text { with neighbors to manage woodlands? }\end{array}$ & $\begin{array}{c}3.43 \\
(1.28)\end{array}$ & 0.81 & 1 & & \\
\hline $\begin{array}{l}\text { - In the future, would you be interested in } \\
\text { working with neighbors to write a } \\
\text { conservation easement agreement to } \\
\text { protect more than one ownership from } \\
\text { development? }\end{array}$ & $\begin{array}{c}3.44 \\
(1.32)\end{array}$ & 0.76 & 1 & & \\
\hline $\begin{array}{l}\text {-In the future, would you be interested in } \\
\text { hiring a forester to market timber from } \\
\text { your property jointly with one or more } \\
\text { neighbors? }\end{array}$ & $\begin{array}{c}3.42 \\
(1.28)\end{array}$ & 0.66 & 2 & 0.70 & $\begin{array}{l}\text { Jointly } \\
\text { market } \\
\text { (CAdev) }\end{array}$ \\
\hline $\begin{array}{l}\text {-In the future, would you be interested in } \\
\text { developing a shared trail system across } \\
\text { multiple ownerships? }\end{array}$ & $\begin{array}{c}3.99 \\
(1.22\end{array}$ & 0.54 & 2 & & \\
\hline $\begin{array}{l}\text {-In the future, would you be interested in } \\
\text { working with a neighbor to jointly } \\
\text { market your properties for development? }\end{array}$ & $\begin{array}{c}4.39 \\
(1.07)\end{array}$ & 0.87 & 2 & & \\
\hline $\begin{array}{l}\text {-In the future, would you be interested in } \\
\text { asking your neighbors to join a group to } \\
\text { lease hunting and recreation access to } \\
\text { your shared properties? }\end{array}$ & $\begin{array}{c}4.35 \\
(1.04)\end{array}$ & 0.60 & 2 & & \\
\hline
\end{tabular}

Likert scale used: 1=Very interested, 2=Somewhat interested, 3= Neutral , 4=Somewhat uninterested, 5= Very uninterested.

${ }^{1}$ Principal Component criteria for selection set at a minimum of 0.50

${ }^{2}$ Principal Component numbers from Varimax rotation

${ }^{3}$ Cronbach's alpha values, selection criteria set at a minimum of 0.70 , survey items with lower values are left to stand alone. 
Table 16. Description of PC variables and others to use in logistic model

\begin{tabular}{|c|c|c|}
\hline PC Variables & Description of Pc Variable & Code \\
\hline \multicolumn{3}{|l|}{ Reasons to Own } \\
\hline - Nature & Protect environment, wildlife habitat, remain natural & Coded 1 if \\
\hline - Recreation & Recreation, privacy and rural style & very \\
\hline - Real state & Real estate investment & important, \\
\hline - Tradition & Family tradition & otherwise 0 \\
\hline - Timber & Income & \\
\hline \multicolumn{3}{|c|}{ Attitudes \& actions in cross-boundary cooperation } \\
\hline - Steward & $\begin{array}{l}\text { A good steward has an obligation to future generations, } \\
\text { environment, wildlife, habitat and biodiversity }\end{array}$ & $\begin{array}{l}\text { Coded } 1 \text { if } \\
\text { strongly }\end{array}$ \\
\hline $\begin{array}{l}\text { Sense } \\
\text { Community }\end{array}$ & $\begin{array}{l}\text { Sense of community with neighbors; know their forest land } \\
\text { objectives and those are compatible with my own }\end{array}$ & $\begin{array}{l}\text { agree, } \\
\text { otherwise } 0\end{array}$ \\
\hline $\begin{array}{l}\text { - Development } \\
\text { wellcome }\end{array}$ & Development is welcome/ treat & \\
\hline - Share & $\begin{array}{l}\text { Sharing land for recreation with neighbors (trail)/rejecting } \\
\text { people }\end{array}$ & \\
\hline - EcoHealth & $\begin{array}{l}\text { Considering health of nearby properties in decisions related to } \\
\text { forestland }\end{array}$ & \\
\hline $\begin{array}{l}\text { - Communicate } \\
\text { Decisions }\end{array}$ & Communicating with neighbors about management & \\
\hline \multicolumn{3}{|c|}{ Barriers to cross-boundary cooperation } \\
\hline - Disagree Use & No cooperate because do not agree the way neighbors use land & Coded 1 if \\
\hline & No cooperate because do not know neighbors & \\
\hline - No Benefits & $\begin{array}{l}\text { Cooperation is time consuming; infringe privacy, no benefits, } \\
\text { satisfied the way things are. }\end{array}$ & otherwise 0 \\
\hline \multicolumn{3}{|c|}{ Proposed Cooperative Activities $(\mathrm{CA})$} \\
\hline $\begin{array}{l}\text { - (Walking tour) } \\
\text { CAmgt }\end{array}$ & $\begin{array}{l}\text { Interested in participating with neighbors in meetings, walking } \\
\text { tour, wildlife management, hiring forester for management plan, } \\
\text { sharing equipment, conservation easement. }\end{array}$ & $\begin{array}{l}\text { Coded } 1 \text { if } \\
\text { very } \\
\text { important, }\end{array}$ \\
\hline $\begin{array}{l}\text { - (Jointly market) } \\
\text { CAdev }\end{array}$ & $\begin{array}{l}\text { Interested in join with neighbors to hire forester to market } \\
\text { timber, market for development, share trail system, lease } \\
\text { hunting and recreation }\end{array}$ & otherwise 0 \\
\hline \multicolumn{3}{|c|}{ Other independent variables to use in the analysis } \\
\hline MGTACTPROP & Activities: tree plant, wildlife mgt, timber improve, invasive sps, & $\mathrm{Yes}=1, \mathrm{no}=0$ \\
\hline FSPLAN & Have Forest Stewardship Plan & Yes $=1, \mathrm{no}=0$ \\
\hline MGTDECISION & Who takes management decisions & Yes $=1, \mathrm{no}=0$ \\
\hline SELLPROP* & Planning sell property & Yes $=1, \mathrm{no}=0$ \\
\hline ACQUIRE* & How property was acquired (purchase, gift, inherited) & Yes $=1, \mathrm{no}=0$ \\
\hline SOLDTIMB & Have ever sold timber & Yes $=1, \mathrm{no}=0$ \\
\hline DISCUSSMGT & Discuss management with professional & Yes $=1, \mathrm{no}=0$ \\
\hline EDUCATION & From some High School to Ph. D. (some college or higher =1) & Yes $=1, \mathrm{no}=0$ \\
\hline INCOME & $>\$ 60,000=1,<\$ 60,000.00=0$ & Yes $=1, \mathrm{no}=0$ \\
\hline GENDER & Female $=1$, Male $=0$ & $\mathrm{~F}=1, \mathrm{M}=0$ \\
\hline
\end{tabular}


Table 17. Results from logistic regression for $\boldsymbol{C A m g t}$ and independent PC variables

\begin{tabular}{lrlllr}
\hline $\begin{array}{l}\text { Explanatory } \\
\text { Variable }\end{array}$ & N & OR & $\begin{array}{c}\text { 95\% } \\
\text { Confidence Limits }\end{array}$ & P $<\chi^{2}$ \\
\hline Reasons to Own & \multicolumn{5}{c}{ Ow } \\
NATURE & 279 & 2.324 & 0.650 & 8.307 & 0.195 \\
RECREATION & 293 & 0.491 & 0.110 & 2.198 & 0.352 \\
REALESTATE & 274 & 1.197 & 0.617 & 2.322 & 0.596 \\
TRADITION & 276 & 1.314 & 0.607 & 2.844 & 0.488 \\
TIMBER & 274 & 1.012 & 0.503 & 2.037 & 0.974 \\
Attitudes \& actions in cross-boundary & cooperation & & \\
WATER & 269 & 1.014 & 0.509 & 2.023 & 0.968 \\
COMMUNITY & 277 & 1.417 & 0.729 & 2.751 & 0.304 \\
DEVELOPMENT & 286 & 1.135 & 0.592 & 2.177 & 0.703 \\
SHARE & 286 & 2.174 & 0.887 & 5.328 & 0.090 \\
ECOHEALTH & 278 & 1.538 & 0.730 & 3.240 & 0.258 \\
COMMUNIC & 280 & 1.335 & 0.569 & 3.133 & 0.506 \\
Barriers to cross-boundary cooperation & & & \\
DISAGREEUSE & 272 & 0.762 & 0.325 & 1.784 & 0.531 \\
UNKNOWNEIGHB & 274 & 1.076 & 0.392 & 2.956 & 0.887 \\
NOBENEFIT & 285 & 0.122 & 0.053 & 0.280 & $<\mathbf{0 . 0 0 1}$ \\
\hline
\end{tabular}

Table 18. Results from logistic regression for CAdev and independent PC variables

\begin{tabular}{lcccrc}
\hline $\begin{array}{l}\text { Explanatory } \\
\text { Variable }\end{array}$ & $\mathrm{N}$ & OR & \multicolumn{2}{c}{$\mathbf{9 5 \%}$} \\
Confidence Limits & P $<\chi^{2}$ \\
\hline Reasons to Own & \multicolumn{7}{c}{} \\
NATURE & 279 & 0.368 & 0.078 & 1.734 & 0.206 \\
RECREATION & 293 & 0.377 & 0.070 & 2.033 & 0.257 \\
REALESTATE & 274 & 1.540 & 0.563 & 4.215 & 0.401 \\
TRADITION & 276 & 1.089 & 0.349 & 3.399 & 0.883 \\
TIMBER & 274 & 1.633 & 0.592 & 4.505 & 0.343 \\
Attitudes \& actions in cross-boundary & cooperation & & \\
WATER & 269 & 2.640 & 0.830 & 8.400 & 0.100 \\
COMMUNITY & 277 & 1.257 & 0.435 & 3.629 & 0.673 \\
DEVELOPMENT & 286 & 0.493 & 0.190 & 1.278 & 0.146 \\
SHARE & 286 & 5.500 & 1.970 & 15.351 & $\mathbf{0 . 0 0 1}$ \\
ECOHEALTH & 278 & 0.679 & 0.221 & 2.079 & 0.497 \\
COMMUNIC & 280 & 0.660 & 0.830 & 8.400 & 0.587 \\
Barriers to cross-boundary cooperation & & & \\
DISAGREEUSE & 272 & 0.729 & 0.171 & 3.097 & 0.668 \\
UNKNOWNEIGHB & 274 & 2.542 & 0.621 & 10.393 & 0.194 \\
NOBENEFIT & 285 & 0.172 & 0.041 & 0.719 & $\mathbf{0 . 0 1 6}$ \\
\hline
\end{tabular}


Variables associated with management activities and demographic characteristics in a binary form were also used as independent variables to measure willingness to participate using the logistic regression analysis. Results of the comparison of CAs variables with those are presented in Tables 19 and 20 (statistically significant values are bold).

To run the logistic model the variable product of the reduction were inserted in the model as a group as well as the other independent variables selected for the analysis. It was expected that a variable such as FSPLAN would remain statistically significant, nevertheless it was dropped. By looking at a frequency table of the variable we were able to see that out of 291 respondents only 27 had Forest Stewardship plan which could be the reason why it was dropped. Why the variables NATURE and RECREATION did not remain significant (frequencies were high for both variables) could be because even when these are very important reasons to own they were not as good as the three remaining variables to predict the outcomes.

Table 19. Results from logistic regression for CAmgt and other independent variables

\begin{tabular}{lccccc}
\hline $\begin{array}{l}\text { Explanatory } \\
\text { Variable }\end{array}$ & N & OR & $\begin{array}{c}\text { 95\% } \\
\text { Confidence Limits }\end{array}$ & P< $\boldsymbol{\chi}^{\mathbf{2}}$ \\
\hline Management/ownership* & & & & & \\
MGTACTPROP & 240 & 1.256 & 1.027 & 1.536 & $\mathbf{0 . 0 2 7}$ \\
FSPLAN & 291 & 1.614 & 0.477 & 5.453 & 0.441 \\
MGTDECISION & 279 & 0.654 & 0.318 & 1.342 & 0.247 \\
SELLPROP* & 284 & 0.903 & 0.391 & 2.082 & 0.810 \\
ACQUIRE* & 285 & 0.772 & 0.296 & 2.015 & 0.597 \\
SOLDTIMB & 287 & 0.645 & 0.323 & 1.288 & 0.214 \\
DISCUSSMGT & 292 & 1.155 & 0.528 & 2.529 & 0.718 \\
Demographics & & & & & \\
EDUCATION & 281 & 2.869 & 1.303 & 6.319 & $\mathbf{0 . 0 0 9}$ \\
INCOME & 236 & 0.909 & 0.461 & 1.796 & 0.785 \\
GENDER & 285 & 0.666 & 0.296 & 1.497 & 0.326 \\
\hline
\end{tabular}


Table 20. Results from logistic regression for Cadev and other independent variables

\begin{tabular}{|c|c|c|c|c|c|}
\hline \multirow{2}{*}{$\begin{array}{l}\text { Explanatory } \\
\text { Variable } \\
\text { Management/ow }\end{array}$} & \multirow[t]{2}{*}{$\mathrm{N}$} & \multirow[t]{2}{*}{ OR } & \multicolumn{2}{|c|}{$\begin{array}{c}95 \% \\
\text { Confidence Limits }\end{array}$} & \multirow[t]{2}{*}{$\mathbf{P}<\chi^{2}$} \\
\hline & & & & & \\
\hline MGTACTPROP & 240 & 0.911 & 0.643 & 1.290 & 0.599 \\
\hline FSPLAN & 291 & 3.542 & 0.587 & 21.357 & 0.168 \\
\hline MGTDECISION & 279 & 0.972 & 0.269 & 3.508 & 0.965 \\
\hline SELLPROP* & 284 & 1.385 & 0.362 & 5.292 & 0.634 \\
\hline ACQUIRE** & 285 & 0.942 & 0.131 & 6.788 & 0.953 \\
\hline SOLDTIMB & 287 & 1.540 & 0.494 & 4.801 & 0.456 \\
\hline DISCUSSMGT & 292 & 0.949 & 0.223 & 4.038 & 0.944 \\
\hline \multicolumn{6}{|l|}{ Demographics } \\
\hline EDUCATION & 281 & 7.701 & 0.910 & 65.168 & 0.061 \\
\hline INCOME & 236 & 0.676 & 0.203 & 2.248 & 0.523 \\
\hline GENDER & 285 & 0.187 & 0.022 & 1.564 & 0.122 \\
\hline
\end{tabular}

Table 21. Variables to measure willingness to participate in CA

\begin{tabular}{lccccc}
\hline $\begin{array}{l}\text { Explanatory } \\
\text { Variable }\end{array}$ & N & OR & $\begin{array}{c}\text { 95\% } \\
\text { Confidence Limits }\end{array}$ & P $<\chi^{2}$ \\
\hline CAmgt & & & & & \\
MGTACTPROP & 236 & 1.323 & 1.105 & 1.584 & 0.0023 \\
EDUCATION & 273 & 2.565 & 1.261 & 5.218 & 0.0093 \\
NOBENEFIT & 279 & 0.098 & 0.045 & 0.213 & $<.0001$ \\
CAdev & & & & & \\
SHARE & 282 & 5.038 & 2.136 & 11.881 & 0.0002 \\
NOBENEFIT & 280 & 0.294 & 0.098 & 0.887 & 0.0299 \\
\hline
\end{tabular}

The variables NOBENEFIT, EDUCATION and MGTACTPROP remained statistically significant $(\mathrm{p}<0.05)$ when compared to CAmgt; while in the case of CAdev the variables SHARE and NOBENEFIT remained statistically significant.

The comparison of CAmgt and the variables of interest showed that PF Owners currently involved in "Management Actions on property"(MGTACTPROP) are the group most likely to become involved in CAmgt (40\% are willing to participate and the odds of participation are 1.32 to one). The variable MGTACTPROP included seven actions. 
Education had a large effect on PF owners becoming involved in CAmgt. Owners with college education are 2.57 times (odds ratio) more likely to participate in management than those with less education; with just $23 \%$ of those with trade or technical school education being willing, whereas this percentage increased to $44 \%$ for PF owners with a college education.

The odds of having people that agree with the statement "no cooperation benefits" to participate in CAmgt were negative (0.098 to 1). Willingness to participate in CAmgt increased from a low of $10 \%$ (those that agree no cooperation benefits exist) to $52 \%$ for respondents that do not agree with the statement that no cooperation benefits exist.

The comparison of CAdev and the variables of interest showed that, 34\% of PF owners who agreed with sharing development (SHARE) were willing to market jointly (CAdev), but even among those PF owners who did not agree with SHARE, 7-8\% were willing to participate in CAdev. The odds of having someone that "agree" with SHARE collaborating in CAdev are of 5 to 1 . Caution should be exerted when using this values considering that the frequency of respondents agreeing with SHARE and CAdev was of only 37 people, while 228 respondents did not wanted to participate neither in SHARE nor in CAdev.

Of those that agreed with the statement "no cooperation benefit" (NOBENEFIT), 5\% are willing to cooperate in CAdev, while those that did not agreed with the statement, $15 \%$ ate willing to market jointly. The odds of having someone that agree that "no cooperation benefit" exist participating in CAdev are negative (0.294 to 1$)$. When assessing the willingness to cooperate no significant difference was found among counties. 


\section{CHAPTER FIVE: DISCUSSION}

Of all the PC variables (14) resulting from the grouping of reasons to own, attitudes and actions in cross boundary cooperation and barriers to cross-boundary cooperation only two

(NOBENEFIT and SHARE) remained significant in the logistic model. Of all the variables from demographic characteristics (age, income, education and sex) only EDUCATION remained, and of those related to ownership or management activities (MGTACTPROP, FSPLAN, MGTDECISION, DISCUSSMGT, SOLDTIMB, ACQUIRE, SELLPROP) only MGTACTPROP remained significant in the logistic model. The results of this study suggests that PF owners are more inclined to participate in cooperative activities based on their attitudes (SHARE), beliefs (NOBENEFIT ) and education or what they are already doing (MGTACTPROP).

Long term residence is considered to have a negative impact regarding conservation easement (Brenner et al.,2013), we did not have data regarding years of residence but a comparison of the dependent variables (CAmgt, CAdev) and the variable residency gave very similar percentages of willingness to participate in the CAs among residents and non-residents. To better explain the results we also looked at the responses of individual variables included in the composite variables CAmgt and CAdev. The question "would you be interested in working with neighbors to write a conservation easement agreement" was included in CAmgt and the response pointed to "uninterested" (mean 3.44), however when respondents were asked if they were familiar with CE, 56\% said "no". Even when the response about CE is negative we cannot discard that the lack of knowledge about the subject is affecting their willingness to participate.

A study conducted in Wetzel County WV found that losing control of properties was a significant concern among woodland owners in relation to long term timber leases (McGill et al., 
2008). Results obtained in our study from the comparison of the variables SHARE and CAdev probably point toward this concern. Both variables included commitments related to allowing people in their properties to develop a trail system. Even when we obtained an odds ratio of 55 to 1 and a $34 \%(\mathrm{~N}=12)$ for those giving a positive answer were willing to participate in SHARE and CAdev, we still had $92 \%(\mathrm{~N}=228)$ woodland owners who did not want to participate in either of the CA variables. By looking at the variables that made up SHARE we found that $78 \%$ of respondents were in disagreement of allowing building a trail across their land and $84 \%$ did not wanted neighbors doing recreational activities in it. A way to approach these PF owners could be by ensuring them that they can still participate in cooperative activities such as the control of invasive species, fire prevention, and wildlife habitat management and still keep complete control of their properties.

Regarding the results obtained for MGTACTPROP and CAmgt, those that are doing management activities in their properties are 1.32 times (from odds ratio) more likely to get involved in CAmgt than those who do not perform activities. Similarly a study about NIPF owners of WV included a model where the relationship between property management activities and landowners' decisions to manage their forest was examined (Joshi \& Arano, 2009). They found that management characteristics were associated with the forest management practices they were engaged in; they also pointed out that those forest owners with non-timber objectives (our case) were as inclined to participate in forest management as those with timber objectives. Those findings confirm that MGTACTPROP is a strong predictor of PF owner's behavior. These woodland owners are good candidates to participate in programs that are already in place such as the Stewardship Program. 
EDUCATION was significant, it obtained the highest odds ratio among the variables correlated with CAmgt ; those who have a college education are 2.23 times more likely to get involved in CAmgt activities than those with less education. Joshi and Arano (2009) like in our study also found that education is a significant predictor of landowner behavior and that those with a higher level of education are more likely to participate in silvicultural activities. Peer to peer learning has been found to be successful in attracting woodland owners possessing a forestry background and also those who do not (Ma, Kittedge \& Catanzaro, 2011). This approach could be used to motivate those woodland owners with technical education or less in getting involved in cooperative activities.

The composite variable NOBENEFIT was significant and negatively associated to willingness to cooperate in either of the CAs variables. Results indicate that those who perceive that no cooperation benefits exists are less likely to participate in either of the CAs activities as the results in the odds ratios show $(\mathrm{Cadmgt}=0.094, \mathrm{CAdev}=0.294)$

Considering that this study was designed after a study of Finley et al. (2006) to examine the attitudes, motivations and barriers to cross-boundary cooperation of PF owners in our five areas of interest a brief contrast of our finding and those of the other study are presented. Finley et al. (2006) found that variables identified as the strongest discriminators were STEWARD, SHARE, AVOID NEIGHBORS ${ }^{2}$, and NOBENEFIT. Their study reports that all variables identified as barriers were left to stand alone due too poor PC loadings. In our case PC loadings were high enough (0.58-0.84) to justify a grouping of the barrier variables. We ended up having three PC variables: UNKNOWNEIGH, DISGREEUSE AND NOBENEFIT. In the case of NOBENEFIT this variable accounts for the grouping of 6 barrier survey items, indicating that in our case there

\footnotetext{
${ }^{2}$ This variable was called KNOWBETTER in this study
} 
is an underlying structure where the most variance of responses exists. This suggests that PF owners are negatively inclined in those aspects of cooperation represented in the NOBENEFIT variable.

The reduction process of the initial variables for both Finley et al. (2006) and this study were very similar. However after that we followed a different path, in the study of Finley et al. (2006), they followed a 2 phase strategy to segment respondents, first using the ten CA variables to define 4 segments and in a second phase ranked the association between segments using the variables related to ownership, barriers, attitudes and actions along with other variables such as income and timber. In this study the ten $\mathrm{CA}$ variables produced the two $\mathrm{PC}$ variables aforementioned.

Following a social marketing approach PF owners were segmented by the Sustaining Family Forests Initiative (SFFI) as model owners, prime prospects, potential defectors and write-offs (Butler et al., 2007). Similarly in the study of Finley's et al. (2006) four segments were delimited: 1) No cooperator 2) Conservation cooperator 3) General cooperator and 4) Neutralist. In this study we did not define landowners types, however we used the CA variables in conjunction with the four remaining significant variables of the reduction process (MGTACTPROP, EDUCATION SHARE and NOBENEFIT) to measure the willingness to cooperate, identifying in this manner cooperators and non-cooperators and their activities of interest. The variables MGTACTPROP and EDUCATION allowed us to identify those willing to cooperate (in CAmgt and CAdev) while the variable SHARE and NOBENEFIT help to identify barriers to cooperative activities. The variable STEWARD was found of little use in our study (did not help to explain variance) however remained significant in Finley et al. (2006) study. Unlike in our case barrier variables did not produce PC variables in the study of Finley et 
al. (2006). These differences are hard to explain without accessing their data because no great differences stand up in the data available. Besides the differences in response rate, when comparing mean values and standard deviations for those variables in both studies differences between means range from 0.02 to 0.07 except in one case (too many commitments where the difference is 0.53.), regarding the standard deviations differences were not greater than 0. 24 . We think it is possible that the study of Finley et al. (2006) could be replicated in it full extent, nevertheless we decided that our approach provided enough parameters to measure willingness of PF owners to cooperate and the barriers to it.

There are some variables that were dropped during the reduction process in this study that merit some attention and which are referred in the next paragraphs. When asked "Have your neighbors or owners of nearby properties spoken to you about their management decisions?" the mean response value obtained in this study was 1.50 (variable COMMUNICATE) falling in the category "never" and "rarely", with an odds ratio of 1.34 to 1 , when correlated with CAmgt. Regarding the ecological health (ECOHEALTH) of nearby properties, respondents showed a positive attitude toward the issue (mean response value of 2.86 ), with an odds ratio of 154 to 1 , when correlated with CAmgt. But, although PF owners might be willing to consider the ecological health of neighboring properties they can do nothing about it unless communication is established. Collaboration has been found one of the most difficult issues to address when trying to reach thousands of PF owners in the United States and communication has been identified as a major barrier to it (Jacobson, Abt \& Carter, 2000). Research on a pilot project (Wood Forum) in Massachusetts presents peer learning as an effective approach to engage underserved PF audiences; suggesting that an increase in willingness of respondents to share information increasing communication among them (Ma, Kittredge \& Catanzaro,2011). These findings 
might help decision makers to consider communication needs in future outreach programs (or those already in place) by stressing the establishment of communications bridges among PF owners, covering the existing gaps of information while promoting forest management beyond the individual parcel.

The most valuable benefits of participation in conservation organizations identified by PF owners in this study included knowledge (27\%, also reported as education and information), protection of natural resources (25\%) and sharing/helping others (18\%). A study in South Carolina found that NIPF owners involved in cooperatives were eight times more likely to get involved in joint planning (Jacobson, Abt \& Carter, 2000), yet no studies have been conducted to find out if there is a significant relationship between participation in natural resources organizations and willingness to cooperate across boundaries. While we did not conduct a statistical test of significance in responses related to participation in conservation organizations this might be an aspect to explore.

Reasons to own and threats were other aspects covered in this study. Similarly to other studies related to PF owners, NATURE and RECREATION were identified as the primary reasons to own and TIMBER the least frequent. Considering that eminent risk makes people more willing to act and cooperate (Fischer \& Charnley, 2012), the question "In your opinion what are the main threats to forestland in your landscape area?" was included. Responses varied by county, development being the main concern in Berkeley and Jefferson (38\% and 42\%); this was expected considering their proximity to Washington DC. Mining/gas and oil activities were perceived as the main threats by respondents from Marion, Marshall, and Ritchie $(60 \%, 40 \%$ and $20 \%$ respectively) which was also expected, given the scale of these activities in those areas. Marion and Cabell perceived pest as a threat (34\% and, 31\% respectively). For future 
approaches to these counties the inclusion of "threats" in their agenda should be considered in a regular basis to educate people about the subject.

Landscape scale forestry is a current trend arisen from the need of ecosystem management beyond the parcel boundaries; the concept has been promoted by the USDA FS in their latest publications program and projects. Under those considerations it is suggested that further work should evaluate the set of answers related to landscape. Additional information about how landscape is perceived and what are the threats to it could be helpful to promote the idea of landscape scale forest management.

To ensure that sample size is large enough to conduct PCA, sending a larger number of survey questionnaires is suggested. The inclusion of a more detailed section regarding management activities conducted in the property could help to shed more light in the activities performed by PF owners in their properties. 


\section{LITERATURE CITED}

Act of May 20, 1862 (Homestead Act). (1862). Public Law 37-64 Record Group 11. General Records of the United States Government. National Archives. Retrieved from http://www. ourdocuments. gov/doc. php?flash=true\&doc=31

Arnstein, S. R. (1969). A Ladder of Citizen Participation. Journal of the American Institute of Planners, 35(4), 216-224. Retrieved from http://lithgow-schmidt. dk/sherryarnstein/ladder-of-citizen-participation_en.pdf

Belin, D., Kittredge, D., Stevens, T., Dennis, D., Scweik, C., \& Morzuch, B. (2005). Assessing Private Forest Owner Attitudes Toward Ecosystem-Based Management. Journal of Forestry, 28-35. Retrieved from: http://harvardforest. fas. harvard. edu/sites/harvardforest. fas. harvard. edu/files/publications/pdfs/Belin_JofForestry_2005. pdf

Bengston, D.N., S.T. Asah, and B.J. Butler. (2011). The Diverse Values and Motivations of Family Forest Owners in the United States: An Analysis of an Open-ended Question in the National Woodland Owner Survey. Small-scale Forestry 10(3): 339-355. Retrieved from: http://www.nrs.fs.fed.us/pubs/jrnl/2011/nrs 2011 bengston_001.pdf

Brenner, J.C., Lavallato, S., Cherry,M., Hileman, E.(2013). Land use determines interest in conservation easements among private landowners. Department of Environmental Studies and Sciences, Ithaca College. Ithaca, NY 14850, United States. Land Use Policy 35 (2013) 24-32. Retrieved from www.elsevier.com/locate/landusepol

Birch, T., Lewis, D., \& Kaiser, F. (1982). The private forest-land owners of the United States. Forest Service Resource Bulletin WO-1. US Department of Agriculture, Forest Service.

Butler, B., \& Leatherberry, E. (2004). America's Family Forest Owners. Journal of Forestry, 102(7), 4-14. Retrieved from http://www. postcom. com/eco/sls. docs/USFSFamily\%20forests\%20article. pdf

Butler, B. J. (2008). Family Forest Owners of the United States. Gen. Tech. Rep. NRS-27. U. S. Department of Agriculture, Forest Service, Northern Research Station. Retrieved from http://www. nrs. fs. fed. us/pubs/gtr/gtr_nrs27. pdf

Butler, B., Tyrrell, M., Feinberg, G., VanManen,,S., Wiseman, L., \& Wallinger, S. (2007). Understanding and Reaching Family Forest Owners: Lessons from Social Marketing Research. Journal of Forestry, 105(7), 348-357. Retrieved from http://www. fia. fs. fed. us/nwos/documents/understanding. pdf

Butler, B.J., Z. Ma. (2011). Family Forest Owner Trends in the Northern United States. Northern Journal of Applied Forestry 28(1): 13-18. Retrieved from 
http://www.researchgate.net/publication/228659386_Family_Forest_Owner_Trends_in_t he_Northern_United_States/file/50463520952f1bb57f.pdf

Cantiani, M.G. (2012). Forest planning and public participation: a possible methodological approach. iForest , 5, 72-82. Retrieved from http://www. sisef. it/iforest/pdf/?id=ifor0602$\underline{009}$

Carter, J., \& Gronow, J.(2005). Recent Experiences in Collaborative Forest Management. Center for International Forestry Research, (43). Retrieved from http://www. cifor. org/publications/pdf_files/OccPapers/OP-43. pdf

Charnley, S., Long, J., \& Lake, F. (2013). Science Synthesis to Promote Resilience of Socialecological Systems in the Sierra Nevada and Southern Cascades. Department of Agriculture, Forest Service, Pacific Southwest Research Station: 1- 30. Chapter 9. 6. Retrieved from http://www. fs. fed. us/psw/publications/reports/psw_sciencesynthesis/psw-gtr-247_POSTPRINT_7-03-14. pdf

Colosi, R., U.S.(2005). Negatively Worded Questions Cause Respondent Confusion. ASA Section on Survey Research Methods. Retrieved from http://www. amstat. org/sections/srms/proceedings/y2005/Files/JSM2005-000508. pdf

Daniels, S. E.,. Walker, G. B.(2014). Rethinking public participation in natural resource management: Concepts from pluralism and five emerging approaches. Department of Forest Resources. Oregon State University, Corvallis, Oregon. Retrieved from http://lib.icimod.org/record/10051/files/260.pdf

Deloitte. (2011).XBC Creating public value by unleashing the power of cross-boundary collaboration. A GovLab study with Harvard Kennedy Ash Center for Democratic Governance and Innovation. Retrieved from http://www2. deloitte. com/content/dam/Deloitte/global/Documents/Public-Sector/dttl-ps-xbc-08082013. pdf

Dillman, D.A.(2001). Mail and internet surveys: The tailored design method (p. 464). New York: Wiley \& Sons.

FAO-ECE-ILO (2000). Public participation in forestry in Europe and North America. Report of the FAO/ECE/ILO Joint committee team of specialists on participation in forestry. Working paper 163, Sectorial activities department, International labour office, Genève, Switzerland. Retrieved from http://www.unece.org/fileadmin/DAM/timber/docs/publications-other/reportparticipation.pdf

Finley, A., Kittredge, D., Stevens, T., Schweik,,C., \& Dennis, D. (2006). Interest in CrossBoundary Cooperation: Identification of Distinct Types of Private Forest Owners. Forest 
Science, 52(1), 10-22. Retrieved from http://harvardforest. fas. harvard. edu/sites/harvardforest. fas. harvard. edu/files/publications/pdfs/Finley_ForestScience_2006. pdf

Fischer, A. P., Charnley, S.(2012). Risk and cooperation: managing hazardous fuel in mixed ownership landscapes. Environmental Management, 49, 1192-1207. Retrieved from http://www. ncbi. nlm. nih. gov/pmc/articles/PMC3350635/pdf/267_2012_Article_9848. pdf

Hair, J.F.,Tatham, R. L., Anderson, R. E., \& Black, W.(1998). Multivariate Data Analysis. Upper Saddle River, NJ: Prentice Hall.

Hatcher, J. E., Straka, T., Greene, J.L. (2013). The Size of Forest Holding/Parcelization Problem in Forestry: A Literature Review. Resources, 2(2), 39-57. Retrieved from http://www.mdpi.com/2079-9276/2/2/39

Heakal, R. (2014) What Are Economies Of Scale?. Retrieved from http://www.investopedia.com/articles/03/012703.asp

Heilman, G. E., Strittholt J. R., Slosser, N. C., \& Dellasala, D. A. (2002). Forest Fragmentation of the Conterminous United States: Assessing Forest Intactness through Road Density and Spatial Characteristics. BioScience ,52( 5),411-422. Retrieved from http://bioscience. oxfordjournals. org/content/52/5/411. full. pdf

Holdt, B., Civco, D., \& Hurd, J. (2004). Forest Fragmentation Due to Land Parcelization and Subdivision: A Remote Sensing and GIS Analysis. ASPRS Annual Conference Proceedings. Retrieved from http://clear. uconn. edu/publications/research/tech_papers/Holdt_et_al_ASPRS2004.pdf

Hoover, K. (2014). Forestry Provisions in the 2014 Farm Bill (P.L. 113-79). Congressional Research Service, 7-5700. Retrieved from http://nationalaglawcenter.org/wpcontent/uploads//assets/crs/R43431.pdf

Hugosson, M. \& Ingemarson, F. 2004. Objectives and motivations of small-scale forest owners; theoretical modelling and qualitative assessment. Silva Fennica 38(2): 217-231. Retrieved from http://www.silvafennica.fi/pdf/article430.pdf

Jacobson, M. G., Abt, R. C., \& Carter, D. R. (2000). Attitudes toward joint forest planning among private landowners. Journal of Sustainable Forestry, 11(3), 95-112. Retrieved from http://www.tandfonline.com/doi/abs/10.1300/J091v11n03_06\#.U9iZq_ldUWI

Joshi, S., \& Arano, K. (2006). West Virginia forest landowners: a lookc at their characteristics and forest management decision. Proceedings of the Southern Forest Economics Workshop. 
Kilgore, M. A., J. L. Greene, M. G. Jacobson, T. J. Straka, and S. E. Daniels. 2007. The influence of financial incentive programs in promoting sustainable forestry on the nation's family forests [Abstract]. Journal of Forestry 105(4):184-191. Retrieved from http://digitalcommons. usu. edu/sswa_facpubs/9/

Kittredge, D. (2005). The cooperation of private forest owners on scales larger than one individual property: international examples and potential application in the United States. Retrieved from http://hfr. lternet. edu/sites/harvardforest. fas. harvard. edu/files/publications/pdfs/kittredge_ForEcolMan_2005. pdf.

Landscape Scale Forest Stewardship Feasibility Study in West Virginia, Project Proposal. (2011). West Virginia University, Division of Forestry and Natural Resources.

Leong, K., Emmerson, D., \& Byron, R. (2011). The New Governance Era: Implications for Collaborative Conservation and Adaptive Management in Department of the Interior Agencies. Human Dimensions of Wildlife, 16(4), 236-243. Retrieved from http://www. nps. gov/civic/resources/Leong\%20et\%20al_2011_New\%20Governance\%20Era. pdf

Linder, J., Murphy, T., \& Briers, G. (2001). Handling Nonresponse in Social Science Research. Journal of Agricultural Education, 42(4), 43-53. Retrieved from http://pubs.aged.tamu.edu/jae/pdf/Vol42/42-04-43.pdf

MacCleery, D. (2008). Re-Inventing the United States Forest Service: Evolution from Custodial Management, to Production Forestry, to Ecosystem Management (pp. 45-102). Retrieved from ftp://ftp. fao. org/docrep/fao/010/ai412e/ai412e01. pdf

Majumdar, I., D. Laband, L. Teeter, and B.J. Butler. 2009. Motivations and Land-Use Intentions of Nonindustrial Private Forest Landowners: Comparing Inheritors to Noninheritors. Forest Science 55(5): 423-432. Retrieved from http://www.researchgate.net/publication/48854675_Motivations_and_LandUse_Intentions_of_Nonindustrial_Private_Forest_Landowners_Comparing_Inheritors_to Noninheritors

Ma, Z., Kittredge, D. B., Catanzaro, P. (2011). Challenging the Traditional Forestry Extension Model: Insights from the Woods Forum Program. Small- scale Forestry. Retrieved from https://masswoods.net/sites/masswoods.net/files/Challenging\%20the\%20Traditional\%20 Forestry\%20Extension $\% 20$ Model $\% 20$ Insights $\% 20$ from $\% 20$ the $\% 20$ Woods $\% 20$ Forum $\% 2$ 0Program\%20in\%20Massachusetts.pdf

McCuen, M.E. (2012). Landowner Outreach Education Project Evaluation: Connecting New Family Forest Owners with the Professional Forestry Community. Retrieved from http://wvuscholar.wvu.edu:8881/R/?func=dbin-jump-full\&amp;object_id=26157 
McGill, D. W. Grushecky,S. T. . Moss, S., Pierskalla, C, Schuler, A. (2008). Landowner Willingness to Engage in Long-Term Timber Leases in West Virginia, USA. Smallscale Forestry. 7( 2), pp 105-116. Retrieved from http://www. researchgate. net/publication/225203774_Landowner_Willingness_to_Engage_in_Long_Term_Timber_Leases_in_West_Virginia_USA

McGurk, B. C. (2003). Public Involvement in Forest Management and Planning in Manitoba: The Role of Stakeholder Advisory Committees (SACs) (Master's thesis). Retrieved from http://www. umanitoba. ca/institutes/natural_resources/canadaresearchchair/thesis/bmcgurk\%20masters\%20thesis \%202003.pdf

McKinney, M., Scarlett, L., \& Kemmis, D. (2010). Large Landscape Conservation: A Strategic Framework for Policy and Action. Lincoln Institute of Land Policy.

Nelson, P., White, R., \& Molina, R. (2006). The Pacific Northwest Research Station's Biodiversity Initiative: Collaborating for Biodiversity Management. USDA General Technical Report PNW-GTR-670, 670. Retrieved from http://www.fs.fed.us/pnw/pubs/pnw_gtr670.pdf

O'connor, B. P. (2000). SPSS and SAS programs for determining the number of components using parallel analysis and Velicer's MAP test. Behavior Research Methods, Instruments, and Computers, 32(3), 396-402. Retrieved from http://people.hofstra.edu/Jeffrey_J_Froh/files/map\%20and\%20parallel\%20analysis, \%20o 'connor.pdf

PA DCNR (2010). Chapter 4F. Issues, Threats and Opportunities - Energy Development. Retrieved from http://www.pennfuture.org/UserFiles/File/MineDrill/Marcellus/DCNR_pa_ch4f.pdf

Patil, V.H., Singh, S.N., Mishra, S., \& Donavan, D.T. (2008). Efficient theory development and factor retention criteria: Abandon the 'eigenvalue greater than one'criterion. Journal of Business Research, 61(2), 162-170. Retrieved from http://www.sciencedirect.com/science/article/pii/S014829630700152X

Report of the ad hoc technical expert group on forest biological diversity. (n. d). CBD Secretariat. Retrieved from http://www. cbd. int/forest/definitions. shtml

Rickenbach, M., Kittredge, L., Labich, D., \& Shinneman, D. (2011). Cross-Boundary Cooperation: A Mechanism for Sustaining Ecosystem Services from Private Lands. Journal of Soil and Water Conservation, 66(4), 91A-96A. Retrieved from https://preview. ent. iastate. 
edu/nrem/faculty/schulte_moore_lab/files/Rickenbach\%20et\%20al. \%202011\%20JSWC. pd

SAS Institute. (2011). SAS/Share 9.3 User's Guide. Cary, NC: SAS Institute Inc. Retrieved from http://support.sas.com/documentation/cdl/en/shrref/63064/PDF/default/shrref.pdf

Seekamp, E., \& Cerveny, L. K. (2009). Conceptualization of Interactions Between Partners and the U.S. Forest Service. Tree Search, USFS, 105-111. Retrieved from http://www. nrs. fs. fed. us/pubs/gtr/gtr-nrs-p-66papers/16-seekamp-p-66. pdf

Simpson, A., Jarnevich, C., Madsen, J., Westbrooks, R., Fournier, C., \& Mehrhoff, L. (2009). Invasive species information networks: collaboration at multiple scales for prevention, early detection, and rapid response to invasive alien species. Biodiversity, 10(2). Retrieved from

http://www.erc.msstate.edu/publications/docs/2009/09/6294Invasive_species_informatio n_networks-color.pdf

SSI (2014) Tools for Engaging Landowners Effectively. Retrieved from http://www. sustainingfamilyforests. org/

Stevens, J. (1992). Applied Multivariate Statistics for the Social Sciences. Hillsdale, NJ: Lawrence Erlbaum Associates, Publishers.

Survey Sample Size: How many people do I really need to send my survey to? (2013). Retrieved from https://www. surveymonkey. com/mp/sample-size/

The American Association for Public Opinion Research. 2011. Standard Definitions: Final Dispositions of Case Codes and Outcome Rates for Surveys. 7th edition. AAPOR. Retrieved from http://www. aapor. org//AM/Template. cfm?Section=Home

The Prime Prospect Analysis. (2009). Retrieved from http://www. engaginglandowners. org/new-landowner-research/-prime-prospect-analysis

Tomosy, M., Kujawa, G., McNulty, S., Gould B. (2012). Science - management partnerships at the landscape scale: learning from and partnering with the USDA Forest Service. USFS. National Landscape Conservation Cooperative Workshop. Retrieved from http://lccnetwork.org/Content/documents/2012_conference/Monica\%20Tomosy,\%20Gre g\%20Kujawa,\%20Keith\%20Nislow,\%20USFS;\%20and\%20Bill\%20Gould,\%20Caribbea n\%20LCC.pdf

U.S. Census Bureau: State and County QuickFacts (2012). Data derived from Population Estimates, American Community Survey, Census of Population and Housing, State and County Housing Unit. Retrieved from http://quickfacts.census.gov/qfd/states/00000.html 
US Forest Service \& National Association of State Foresters. (2008). Forest Inventory and Analysis National Woodland Owner Survey, FIA Fact Sheet Series. Retrieved from http://www.fia.fs.fed.us/library/fact-sheets/nwos/NWOS\%20Fact\%20Sheet.pdf

U.S. Department of Agriculture, Forest Service. (2014). Invasive Species Program. Retrieved from http://www. fs. fed. us/invasivespecies/role. shtml

USDA Forest Service, Department of Agriculture, Northeastern Area, State \& Private Forestry (2009). Landscape Scale Conservation in the Northeast and Midwest. A Position Paper from the Three Mission Areas1 of the USDA Forest Service: Eastern Region, Northeastern Area, and Northern Research Station; and the Northeastern Area Association of State Foresters. Retrieved from http://www. na. fs. fed. us/stewardship/pubs/conservation/landscale_conservation. pdf

U.S. Department of Agriculture, Forest Service. 2012. National Forest System Land Management Planning. Federal Register. Vol. 77, No. 68. Retrieved from: /http://www. fs. usda. gov/Internet/FSE_DOCUMENTS/stelprdb5362536. pdf

US Department of Agriculture. Forest Service. 2013. National Woodland Owner Survey. Retrieved from: http://www. fia. fs. fed. us/nwos/

US Department of Agriculture. (2011).Report to Congress on Cooperative Forestry Assistance Act and Other USDA Programs That Benefit Private Forests. Retrieved from http://www.fs.fed.us/spf/coop/library/private_forest_report.pdf

U.S. Department of Commerce. (1995). The Ecosystem Approach: Healthy Ecosystems and Sustainable Economies Volume I Overview. Report of the Interagency Ecosystem Management Task Force. Retrieved from http://www.denix.osd.mil/nr/upload/ecosystem1.htm

U.S. Department of Agriculture, Forest Service. (2011). The Principal Laws Relating to USDA Forest Service State and Private Forestry Programs. FS-758. Retrieved from http://www. fs. fed. us/spf/coop/library/SPF-CF\%20handbook. pdf

U.S. Department of Agriculture, Forest Service. (2014). US Forest Service Mission. Retrieved from http://www.fs.fed.us/aboutus/mission.shtml

U.S. Department of Agriculture, Forest Service, Northern Research Station. (2008). Who owns America's forests? Forest ownership patterns and family forest highlights from the National Woodland Owner Survey. NRS-INF-06-08. Retrieved from http://www. nrs. fs. fed. us/pubs/inf/NRS-INF-06-08. pdf

U.S. Department of the Interior. (2014). Bureau of Land Management, U.S. Forest Service and NACo Renew Public Lands Management Partnership. Retrieved from http://www. blm. gov/wo/st/en/info/newsroom/2013/march/NR_03_14_2013. html 
Widmann, R. H., Cook, G. W., Barnett, C. J., Butler, B. J., Griffith, D. M., Hatfield, M. A., Kurtz, C. M., Morin, R. S., Moser, W. K, Perry, C. H., Piva, R. J., Riemann, R., \& Woodall, C. W. (2012). West Virginia's Forests 2008. Resour. Bull. NRS-61 Newtown Square, PA: U.S. Department of Agriculture, Forest Service, Northern Research Station. Retrieved from http://www.fs.fed.us/nrs/pubs/rb/rb_nrs61.pdf

Wilson VanVoorhis, C., \& Morgan, B. (2007). Understanding Power and Rules of Thumb for Determining Sample Sizes. Tutorials in Quantitative Methods for Psychology, 3(2), 4350. Retrieved from http://www. tqmp. org/Content/vol03-2/p043/p043. pdf.

WVDOF. (2010).West Virginia Statewide forest resource assessment. Retrieved from http://www. wvforestry. com/DOF100Assessment_Revised_091310_Part2.pdf 


\section{APPENDIX A. Initial contact cover letter}

December 5, 2013

Dear Woodland Owner:

We would like to invite you to be part of a Landscape Forest Stewardship assessment project in West Virginia. In today's world, forests and woodland ecosystems are under great environmental and social pressure. As a landowner in Jefferson County you have the power to improve environmental quality for your personal well-being and the good of your local community.

West Virginia University's Landscape Forest Stewardship Project is a research project that is exploring how woodland owners and their communities might build conservation partnerships. The goals of this project are intended to:

Assess opportunities for landscape forestry projects in five regions of West Virginia;

Expand awareness about sustainable woodland ecosystems among land owners and their local communities;

Promote healthy forests on large geographic scales by promoting woodland stewardship across property boundaries.

In the coming months we will be sending out invitations to one or more project meetings in your area. Please fill out the enclosed postage-paid postcard to let us know your level of interest in this effort, then drop it back into the mailbox. These postcards are coded with a number that allows us to keep information and addresses separate for confidentiality purposes.

We hope to see you at one of the upcoming gatherings in your area. If you have any questions, please feel free to contact us.

Sincerely,

Ana Maria Erazo, Coordinator Landscape Forest Stewardship Project anamariaerazohn@yahoo.com
Dr. Dave McGill, Principal Investigator Professor/Extension Specialist Email:

Phone: 304-293-5930 


\section{APPENDIX B. Informational package: cover letter and other information}

January 15, 2014

Dear West Virginia Woodland Owner:

Enclosed please find information you requested about Landscape Forest Stewardship. While landscape-scale projects can vary widely depending on their location, unique issues, and community involvement, the enclosed information will provide you with some insight and links to more specific resources.

First you will find a pamphlet on landscape stewardship that is designed to help natural resources professionals as they engage communities. Also enclosed is an information sheet on the Forest Stewardship Program in West Virginia, which outlines a key forestry program related to forest planning on private lands, and lists contact offices by county where you can find direct assistance for your properties. Finally, the small colorful magnet has a link to a website where you can find upcoming woodland-related workshops in your area.

We hope that the information we are providing will give you a better understanding of landscape forest stewardship initiatives and other resources that you can use to learn more about your own woodlands. If you have any further questions, please contact us.

Sincerely,

Ana Maria Erazo, Coordinator Landscape Forest Stewardship Project Email: anamariaerazohn@yahoo.com
Dr. Dave McGill, Principal Investigator Professor/Extension Specialist

Phone: 304-293-5930 


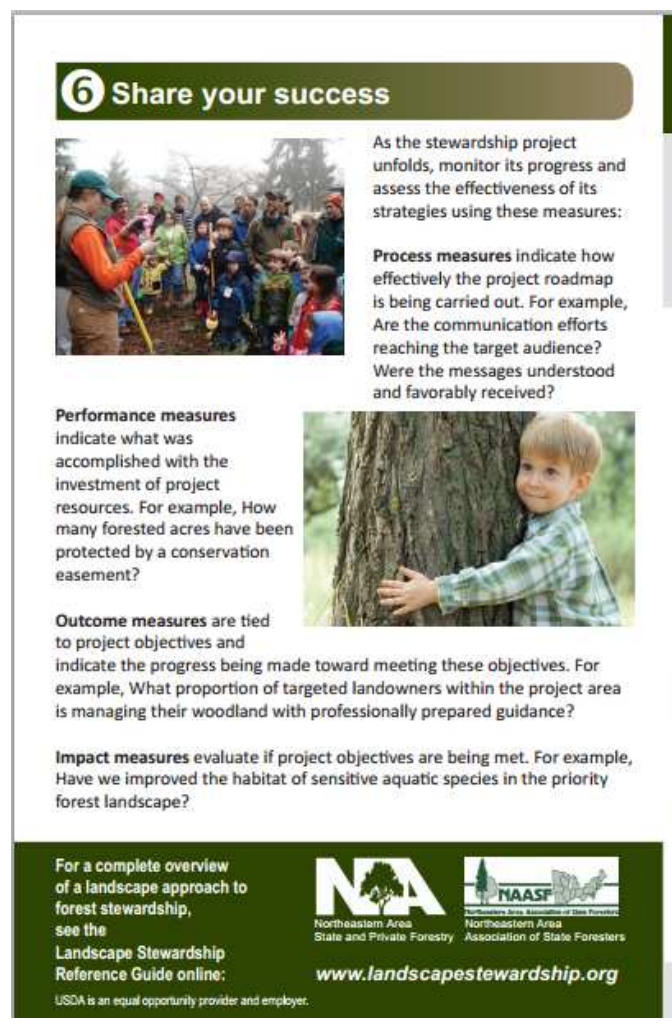

Landscape Stewardship Project A Quick-Start Guide for

Forest Stewardship Program Managers

Landscape stewardship brings together a variety of

partners who have shared interests in the outcomes of forest stewardship. These partners, which need to include public agencies, communities, and forest landowners, among others, agencies, communities, and forest landowners, among others, benefits of sustainably managed forests.

\section{(1) Identify a project area}

Landscape stewardship is an appropriate tool for addressing the issues and opportunities identified in each State's forest Assessment and Strategy. Priority areas identified in this Assessment and Strateg make strong candidates for a landscape stewardship project. For example, a State may have identified a priority area where sensitive aquatic species are in serious decline due in part to inappropriate land management practices. A forest landscape stewardship coordinator can work with other State, Federal, and nongovernmental organizations to build a coalition committed to reversing the decline of these species.

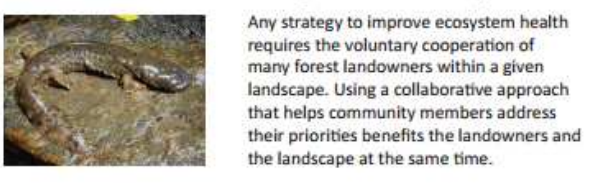

\section{Increasing the reach and influence of forest stewardship}

\section{(2) Engage the community}

The next step is to build a local constituency that will address State and regional issues. Work with community decisionmakers and other stakeholders, including both forest landowners and those who don't own forest land, to identify and agree on priorities for conservation

These priorities should address the community's social, economic, and environmental issues while contributing to the project's resource objectives.

\section{(3) Draft the project roadmap}

There are two important questions to answer when developing a project roadmap:

1. What is the community's vision for its future? The answer to this will frame the long-term outcomes it seeks from its forests.

2. What resources and conditions currently exist in a community's

landscape? This information, especially with respect to private fores ownership, will provide a baseline against which progress can be measured. It is particularly important to not only determine forest landowner objectives and motivations, but to make the connection between community objectives and resource solutions, particularly those that require the participation of private forest landowners.
(4) Build a foundation for success

It's important to be organized before beginning a landstape stewardship project. This includes such things as:

1. Bulding the team that will responsib for making sur responsible for making sure the roadmap is followed, gathering all needed resources, and increasing the ability of partners to contribute to th effort.

2. Aligning and integrating the project with existing State, Federal, and local programs.

3. Initiating training for both public and private sector project participants. 4. Engaging local business leaders and building the financial support needed to address the community's conservation priorities.

\section{5) Achieve your shared vision}

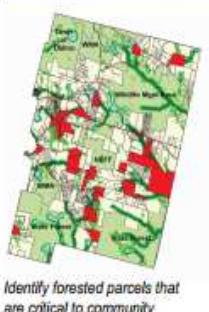

At this point, there should be a coalition of partners, a community-based team that's ready to go, a roadmap that will lead to success, and the resources to get the job done. Achieving a shared vision requires work on two fronts: 1. Creating a political and economic environment that supports private forest stewardship within the project area by conducting outreach and education and guiding public policy.

2. Engaging landowners as forest stewards by promoting conservation marketing. providing meaningful incentives, and offering appropriate technical assistance.

The goal of Forest Stewardship is to sustain the health, productivity, and diversity of the Nation's privately owned forest land to help meet the needs of current and future generations. 


\section{Landscape Stewardship Approach to Forest Management Implementing State Forest Action Plans in Priority Landscapes}

U.S. Department of Agrioulture

Forest Service

Northeostem Area State and Private Forestry

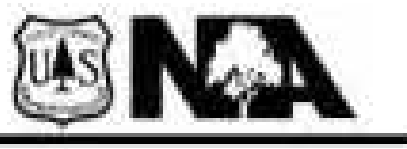

Description: The Forest Stewardship Program encourages States to address natural resource issues outlined in their State Forest Action Plans by strategically targeting technical assistance and by focusing on priority landscapes. The program bas traditionally focused on assisting individual landowners. By contrast, the new "landscape stewardship" approach targets large expanses of land and reaches out to multiple partners, such as forest landowners, public agencies, and communities. By working together, parthers can more effectively focus on important issues, conserve critical resources, and address natural resource management prionties while meeting individual and group goals.

The landscape stewardship concept was developed by the Northeastern Area State and Private Forestry (NA S\&PF) with the State Foresters in the Northeast and Midwest, and was published in the 2011 Landseape Stewardship Guide. In 2012 the concept was incorporated into the Forest Service's aational strategic plan for the Foresr Stewardship Program, ESP 20twenty. States and Territories nationwide are now looking to this concept as they refine their own approaches to landseape stewardship.

\section{Key Issues:}

- State Forest Action Plans call for targeted outreach and technical assistance in priority landscapes.

- States take advantage of competitive grants, but without them many lack the capacity to expand their efforts in priority landscapes.

- Nationwide, the measures needed to capture the outcomes of landscape stewardship are not fully developed.

Accomplishments: Landscape stewardship projects and competitive grant proposals involving landscapes have increased dramatically in the Northeast and Midwest during the past 2 years. Some States are using innovative communications and marketing techniques to reach landowners, with an eye towards expanding the delivery of technical assistance $c$ private forest lands. Some projects are building bridges to other programs, such as Forest Health to address forest pests, and hazardous fuels mitigation to address wildfire related issues. Three projects were featured during NA S\&PF's spring 2012 Landseape Stewardship Webinar series: marketing to landowners in the Driftless Area of Wisconsin, a watcrshedscale landscape project in Maine, and a description of Minnesota's approach to landscape stewardship.

\section{Future Direction:}

- The Northeastern Area State and Private Forestry will continue to promote landscape stewardship to address priorities identified in its strategic plan, Stare Forest Action Plans, and FSP 20twenty.

- SMART, the Stewardship Mapping and Reporting Tool, will be enhaneed so that States can develop and report landscape stewandship plans.

- The Northeastern Area's Forest Stewardship optional metries will continue to provide an opportunity for States to report nontraditional Forest Stewardship accomplishments, success stories, and examples of landscape stewardship approaches.

Tony L. Ferguson, Directar

11 Campus Elvd., Sute 200

Nontown Squore, PA 15073

$510-557-4103$ (-4177 FAX $)$

Hemoueconitis fedua

merw.na.ts.lod.us
Mike Huneke, Program Manager

11 Campus Elvd, Suhe 200

Newtown Square, PA $190 / 3$

$610-557-4110(-4135$ FAX)

mhunekenos. findives

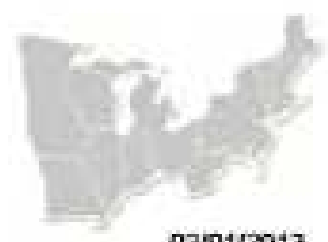

a2/01/2013 


\section{APPENDIX C. Pre- survey postcard}

Notice of Upcoming Survey West Virginia Landscape Forest Stewardship Project

Dear WV Woodland Owner:

A few days from now you will receive a survey designed to gather information about your interests, affiliations and perceptions rel ated to your forested landscape. We are sending this survey to woodland owners in five different areas across West Virginia

Your responses will be used to generate a feasibility report for potential landscape stewardship projects in your area. Your insight can provide valuable information about woodland owners and ways in which they interact with their land and their nei ghbors. This is a research project; West Virginia University Institutional Review Board's acknowledgment of this study is on file.

Please look for this questionnaire in your mailbox. It is with your generous help that this research can be successful. Thank you in advance for your participation.

Dave McGill Pro fessor/Extension Specialist (304) 293-5930; dmcgill@wru.edu

Extension Service

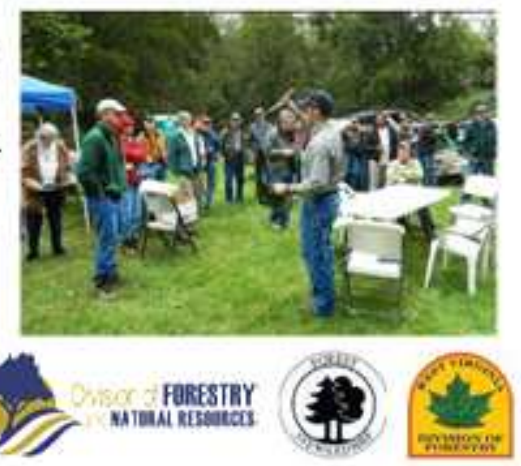


APPENDIX D. Questionnaire/ Master Key

\section{West Virginia}

\section{Landscape Forest Stewardship}

---Woodland Owner Survey ---

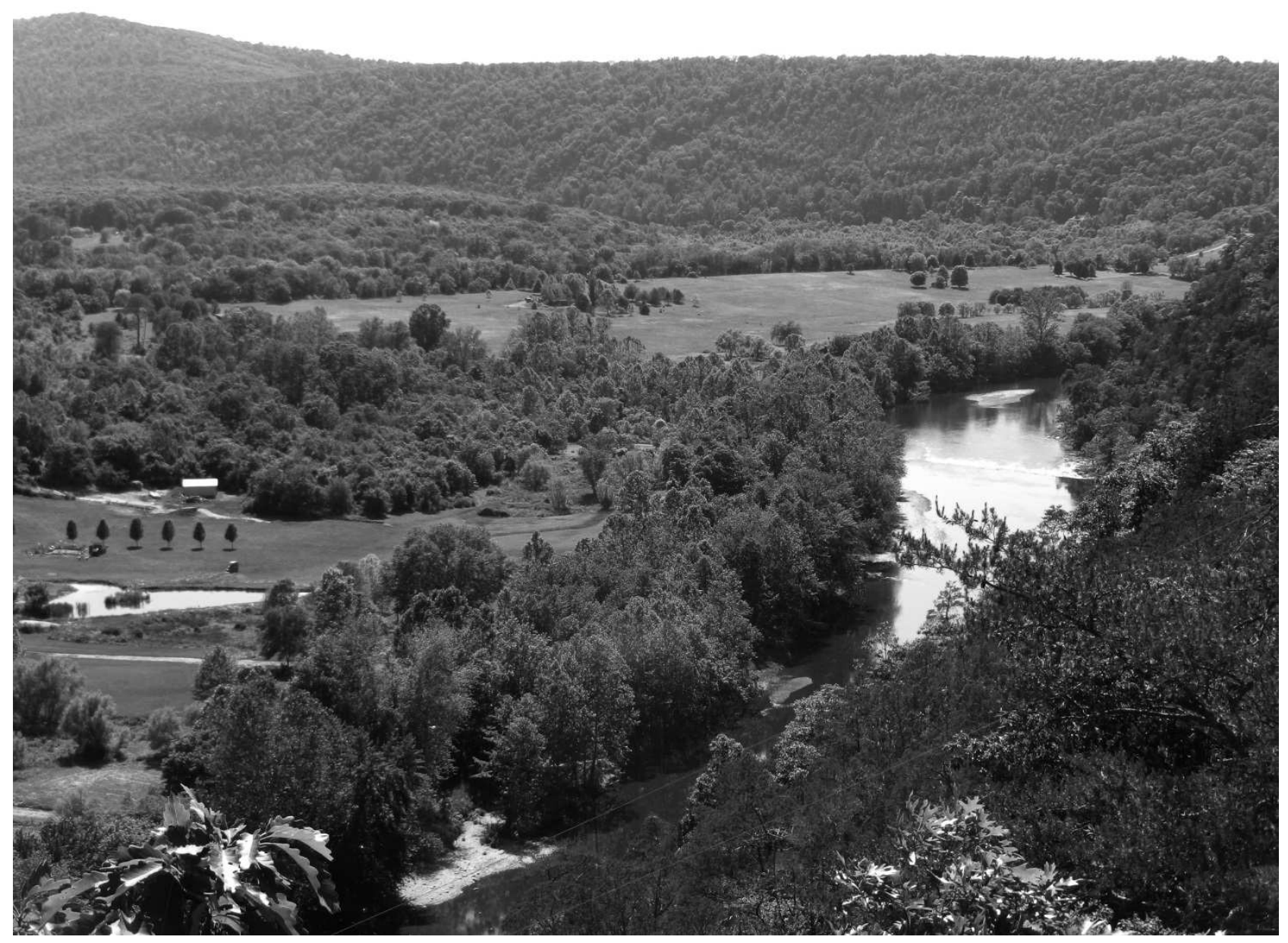

March 2014

Extension Service

WestVirginiaUniversity.
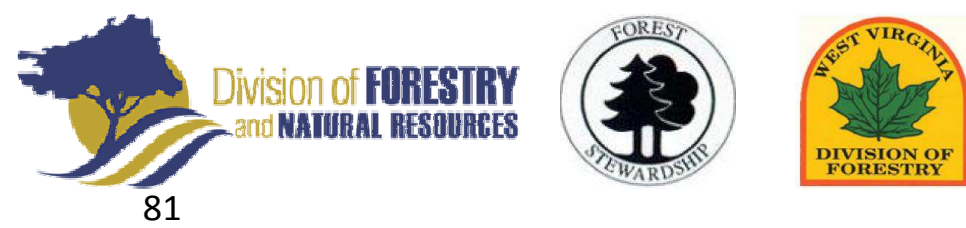


\title{
Please return the completed questionnaire in the postage-paid envelope provided to:
}

\author{
Ana Maria Erazo \\ Percival Hall, Room 329 \\ West Virginia University \\ Division of Forestry \& Natural Resources \\ P.O. Box 6125 \\ Morgantown, WV 26506-6125 \\ Please contact Ana Maria Erazo (anamariaerazohn@yahoo.com; 304-293-5930) if you have any \\ questions.
}

\begin{abstract}
About This Survey
The purpose of this survey is to assess the potential for cross-boundary, landscape forestry projects in your area. These types of projects are usually designed to maintain or improve forest and woodland ecosystems and to address issues, concerns, and opportunities related to forests and woodlands.
\end{abstract}

This survey is part of a Landscape Forest Stewardship project that is exploring how woodland owners and their communities might find new collaborative ways to share visions for environmental partnerships.

The goals of this project are intended to:

- Assess opportunities for landscape forestry projects in five regions of West Virginia;

- Expand awareness about sustainable woodland ecosystems among land owners and their local communities;

- Promote healthy forests on large geographic scales by promoting woodland stewardship across property boundaries.

In today's world, forests and woodland ecosystems are under great environmental and social pressure. As a landowner you have the power to improve environmental quality for your personal well-being and the good of your local community. Your insights will provide helpful information to guide state and local agencies, and private landowners in important landscape-level conservation efforts.

Your participation is voluntary and you have the right to refrain from answering any questions. Please feel free to answer only those questions that you are comfortable answering. If you choose to participate, your answers will be kept confidential. Data will be kept for a minimum of three years following the close of this project.

Thank you for your assistance with this important project!

Instructions:

- Either a pen or pencil may be used.

- When answering questions that require marking a box, please use an " $X$ ".

- If you need to change an answer, please make sure that your old answer is either completely erased or clearly crossed out. 


\section{START HERE: Scale used: $1=$ yes, $0=$ no}

Please carefully read the following items and check the ones that apply.

Please send me a summary of the results of this survey.

I do not own woodland property (please return blank questionnaire).

I do own woodland property (please continue with the questionnaire).

I prefer not to participate in this survey (please return blank questionnaire).

\section{Woodland property ownership}

1) How many $\mathbf{W V}$ properties do you own that have ten acres or more of woodlands?

$\square$ One $\quad \square$ Two $\quad \square$ Three $\quad \square$ More than three. Scale used: 1 to 4

2). With respect to your woodland property in $W V$ that you live on or visit most frequently:
a. How many acres is this property?
b. Approximately how many acres of this property is woodland? acres.
c. In what county is this property?
d. In what year did you take ownership?
e. Do you reside on this property? $\square$ Yes $\square$ No. Scale used: $1=\mathbf{y e s}, \mathbf{0}=\mathbf{n o}$
f. If NO, do you plan to move there in the future? Yes $\square$ No. $\square$ Scale used: 1=yes, $0=$ no, $2=$ does not apply

3). What are your 3 top reasons for owning your property?

a.

b.

c.

4). Which category below best describes your ownership? (Check only one)

Scale used: $1=$ Individual 2 = Family partnership , $3=$ Trust or estate $4=$ Joint, $5=$ Corporation or business partnership, $0=$ does not apply.

\begin{tabular}{|l}
$\square \quad$ Individual \\
$\square \quad$ Family partnership \\
$\square \quad$ Trust or estate
\end{tabular}

$\square \quad$ Joint, such as a husband and wife
$\square \quad$ Corporation or business partnership
$\square \quad$ Other (please specify)_N/A=does not apply

5). Are you planning to sell or transfer any portion of your property in the next 10 years?

$\square$ Yes

No (Skip to Question 6). Scale used: $1=y e s, 0=$ no

If the answer is yes,

a. How many acres will you sell or transfer? acres. Scale used: $0=$ does not apply

b. What is the main reason for selling or transferring? Scale used: $N / A=d o e s$ not appl Main reason:

6). How did you acquire this wooded land in West Virginia? (Check all that apply)

Scale used: $1=$ yes $0=$ no

Purchased

Inherited 


\section{apply}

\section{Woodland activities}

7). Have you ever discussed the management of your woodland property with a professional forester? Scale used: $1=y e s, 0=$ no

$\square$ Yes $\quad \square \quad$ No.

8). Have you personally ever sold timber from this property?

Yes $\square \quad$ No

\section{Scale used: $1=$ yes $0=$ no}

9). What types of activities, if any, do you perform on your property?(Check all that apply)

\section{Scale used: $1=$ yes $0=$ no}
$\square$ Tree planting
$\square \quad$ Invasive species removal
$\square$ Wildlife management
Timber stand improvement
apply
$\square$ Property boundary maintenance/posting

10). Do you currently have a written Forest Stewardship Plan for your woodland?

Scale used: 1=yes, 2=no, 3=I don't Know, 4= no yet

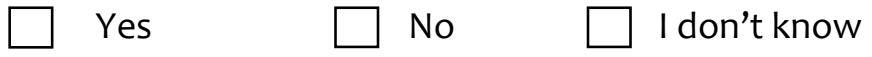

$\square$ I have contacted a forester to do this, but do not have the plan yet.

11). Name a few people that you talk to for advice for forestry or other environmental conservation decisions on your woodland property. (You can use relationships or roles; for example: sister, forester, lawyer, agency, etc.)

a.

12). Who makes the management decisions for your woodland?

Scale used: I do=1, Joint decisions by owners=2, $0=$ does not apply

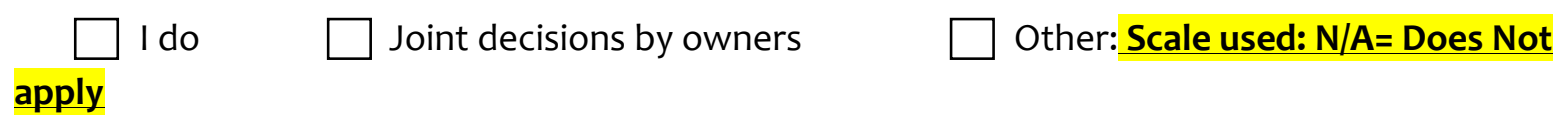

\section{Defining landscapes}

Landscapes mean many things to different people. Generally, "landscape" refers to an area larger than a single property.

This section of the survey is designed to explore how woodland owners view their "landscapes."

13). In a few words, what is the geographical area you consider as your "landscape."

Geographical area:

14). What do you consider the most desirable feature of your woodland landscape? Most desirable feature: 
15). If you had to pick one of the natural resources within your landscape area to protect, which would it be?

Natural resource:

16). In your opinion what are the main threats to forestlands in your landscape area?

Main threats:

Cross boundary Cooperation (scale for this questions was reversed except for items: $f, j, r$ and $y$ ) 17). Please indicate your level of agreement with the following statements. Scale used:

5= Strongly agree, 4=Somewhat agree, 3= Neutral, 2=Somewhat disagree, 1=Strongly disagree

Strongly SgmhleagraleSomewhstrdisggrelesagree

a. I feel an obligation to future generations to be a good steward of my land.

b. We as a society owe it to the environment to be good stewards of the land.

c. It is up to me as a landowner to protect wildlife habitat and biodiversity.

d. I wish my neighbors would enjoy my land more.

e. I would allow my neighbors to build a trail across my land if I could control the type of recreation that occurs on it.

f. The fewer people on my land the better.

g. I find it therapeutic or enjoyable doing things to improve my forestland.

h. I feel great satisfaction when I do things to improve my land.

i. I would like to spend more time enjoying my land.

j. I welcome more development in my town.

k. Housing development in my area will decrease the sense of community.

I. It will take an organized effort among community members to protect forestland from development.

m. I view development as a threat to things I value.

n. I know my neighbors' forestland objectives.

o. I feel that my neighbors' forestland objectives are compatible with my own.

p. I feel a sense of community with my forestland neighborhood.

q. I do not agree with the way my neighbors use

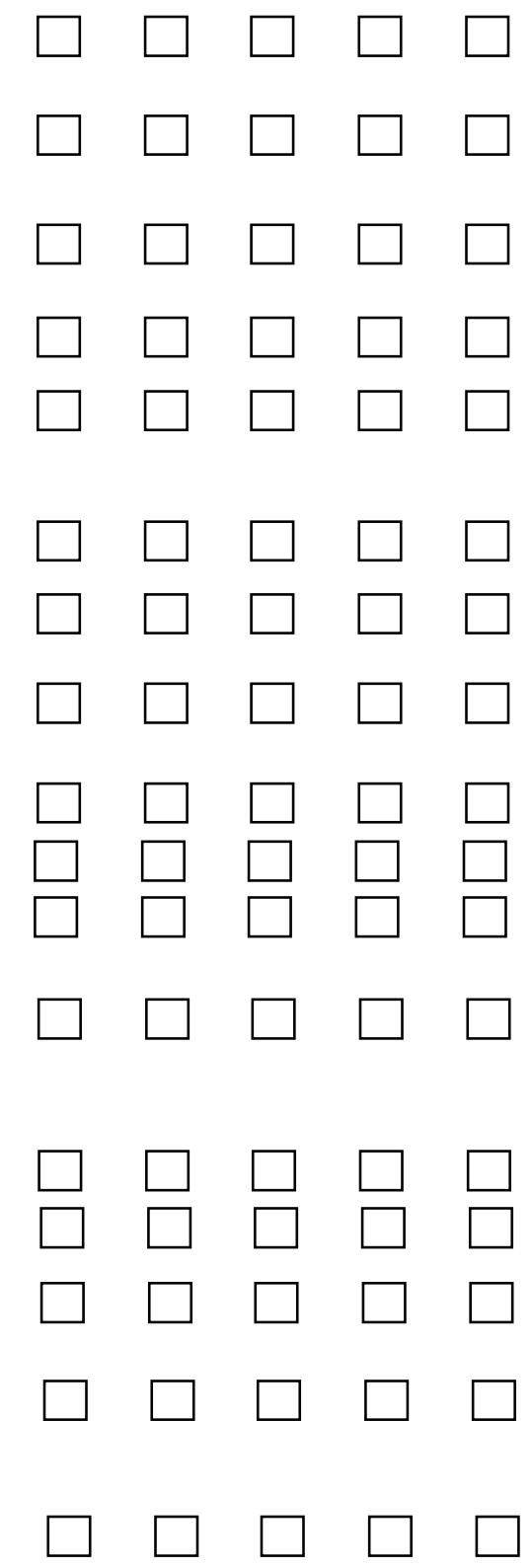


their forestland.

r. I would be interested in cooperating with my neighbors on forest management/conservation initiatives.

s. I would not cooperate with my neighbors because I have too many other commitments in my life.

t. I would not cooperate because I do not know many of my neighbors

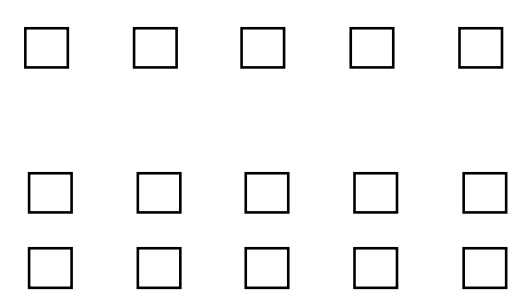

u. I would not cooperate because I am satisfied with the way things are.

v. I would not cooperate because I do not see any benefits from cooperation with my neighbors.

w. Cooperation with my neighbors could infringe on my privacy.

x. Cooperation would be too time consuming.

y. I would like to get to know my neighbors better.

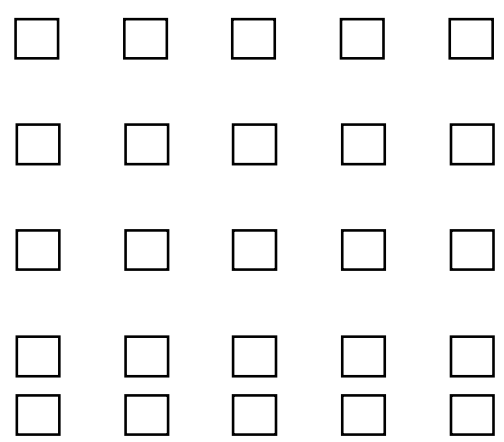

Reasons for owning forestland(scale for this questions was reversed)

Scale used: $5=$ Very important, $4=$ Moderately important, $3=$ Neutral, $2=$ Low importance, $1=$ Not at all important

Please indicate the level of importance with the following statements:

\begin{tabular}{|c|c|c|c|}
\hline $\begin{array}{c}\text { Very } \\
\text { important }\end{array}$ & $\begin{array}{r}\text { Moderately } \\
\text { important }\end{array}$ & Neutral & $\begin{array}{c}\text { Low } \\
\text { importance }\end{array}$ \\
\hline
\end{tabular}

18). I own my land...

... to protect the environment

... to provide wildlife habitat

... to ensure it remains natural

... for the feeling of privacy

...for personal recreation

... because I value a rural life style

... as a real estate investment

... to preserve family and tradition

...for income from timber
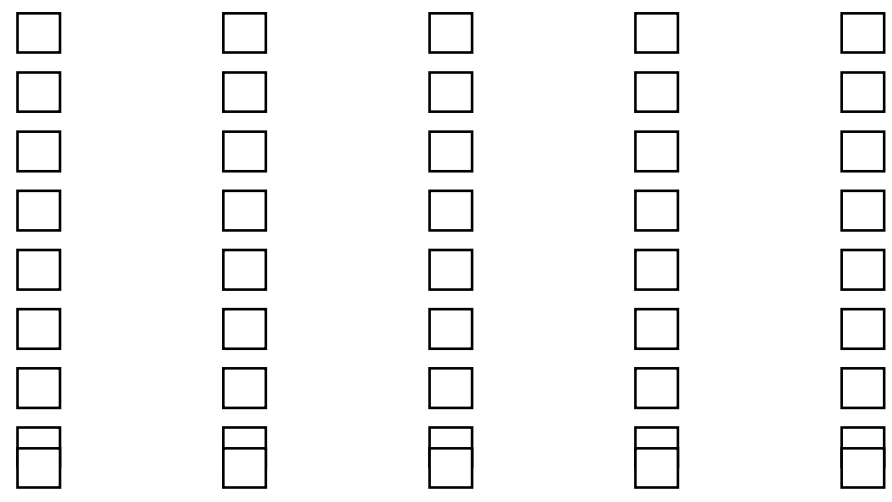

... to protect water source(s) for personal use

... other, Scale: $\mathrm{N} / \mathrm{A}=$ does not apply
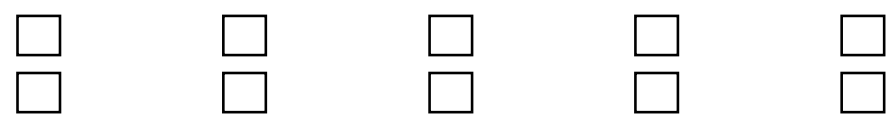

19). Please indicate your position about the following statements 
a. Do you consider the ecological health of neighboring or nearby properties when making decisions concerning your forestland

b. Have your neighbors or owners of nearby properties spoken to you about their management decisions.

\section{Conservation organizations}

20). Do you belong to any local organization(s) related to natural resources? Yes Scale used: $1=$ yes $0=$ no

If YES, how many hours a month do you contribute to the organization(s)? $\mathbf{0}=$ does not apply

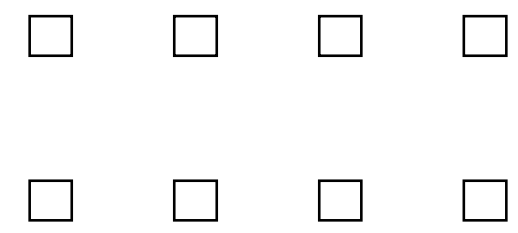

21). Please list the organizations you participate with most frequently.

22). What are the most valuable benefits you get from participating in natural resources organizations?

Cooperative activities(scale for this questions was reversed)

23). Please indicate your level of interest with the following cooperative activities Scale used: 5=Very interested, 4=Somewhat interested, $3=$ Neutral

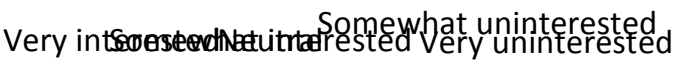
2=Somewhat uninterested $\mathbf{1}=$ Very uninterested

a. In the future, would you be interested in hiring a forester to market timber from your property jointly with one or more neighbors?

b. In the future, would you be interested in developing a shared trail system across multiple ownerships?

c. In the future, would you be interested in working with a neighbor to jointly market your properties for development?

d. In the future, would you be interested in attending a series of meetings on forest management with your neighbors?

e. In the future, would you be interested in joining your neighbors for a walking tour of your collective properties?

f. In the future, would you be interested in talking with your neighbors about managing wildlife habitat together?

g. In the future, would you be interested in sharing the fee for hiring a forester to write a management plan with your neighbors?

h. In the future, would you be interested in sharing forest management equipment with neighbors to manage woodlands?

i. In the future, would you be interested in asking your neighbors to join a group to lease hunting and recreation

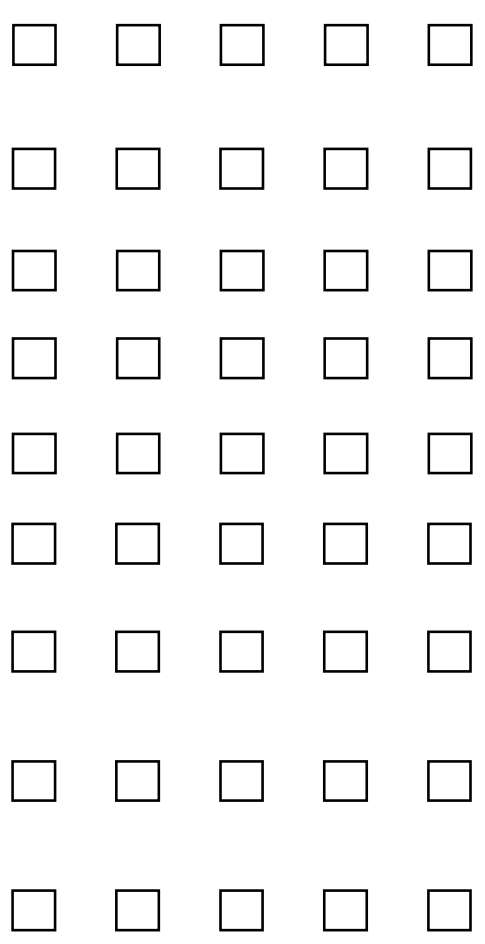


access to your shared properties?

j. In the future, would you be interested in working with neighbors to write a conservation easement agreement to protect more than one ownership from development?

Demographics - Remember your answers are strictly confidential

Please answer the following questions about yourself:

24). What is your gender? $\square$ Female $\square$ Male. Scale used: Female=1, Male= 0

25). What is your age? Scale used: $18-29$ yrs=1, $30-39=2,40-49=3,50-59=4,60-69=5,70+=6$

$\begin{array}{ccc}18-29 y r s & \square 0-49 \square \\ 30-39 \quad & 60-69 \square \\ 50-59 \square & 70+\square\end{array}$

25). What is your current occupation?

26). I reside in:

County

State

27). What is the highest level of education you have completed? (Check only one)

Scale used: Some High School=1, High School Graduate=2,GED=3, Trade or Technical School=4, Some college=5, Associates degree=6, Bachelor's degree=7, Master's degree=8, Ph.D=9

$\square$ Some High School

High School Graduate

GED

Trade or Technical School

Some college
Associates degree

Bachelor's degree

Master's degree

Ph.D

28). What is your average yearly income? (Check only one)

Scale used: Less than $15,000=1, \$ 15,001-\$ 30,000=2, \$ 30,001-\$ 45,000=3, \$ 45,001-\$ 60,000=4$, $\$ 60,001-\$ 75,000=5, \$ 75,001-\$ 90,000=6, \$ 90,001+=7$

\begin{tabular}{|c|c|}
\hline Less than 15,000 & $\$ 60,001-\$ 75,000$ \\
\hline$\$ 15,001-\$ 30,000$ & $\$ 75,001-\$ 90,000$ \\
\hline$\$ 30,001-\$ 45,000$ & $\$ 90,001+$ \\
\hline$\$ 45,001-\$ 60,000$ & \\
\hline
\end{tabular}

Please provide your email address if you are willing to be contacted in the future for further discussions related to landscape stewardship matters. Email:

Thank you for completing this survey! 


\section{APPENDIX E. Reminder postcard}

\section{Reminder About Important Survey}

WV Landscape Forest Stewardship

Dear WV Woodland Owner:

A couple weeks ago we mailed a survey designed to collect in formation about your interests, affiliations and perceptions of forested surroundings as a woodland owner. This is part of a Landscape Forest Stewardship Feasibility Froject conducted by West Virginia University. WVU Institutional Review Board's acknowledgement of this study is on file.

If you have already completed and returned the survey, please accept our sincere thanks. If not, please take a few minutes to do so today. Your insight can provide valuable information that will be used to generate a feasibility report for potential landscape stewardship projects in your area, and help to guide state and local agencies in future landscape level conservation efforts.

If you did not receive a survey or have misplaced it, please call me and I will mail another one immediately. Thank you in advance for your participation.

Dave McGill Professor/Extension Specialist (304) 293-5930; dmcgill@wwu.edu
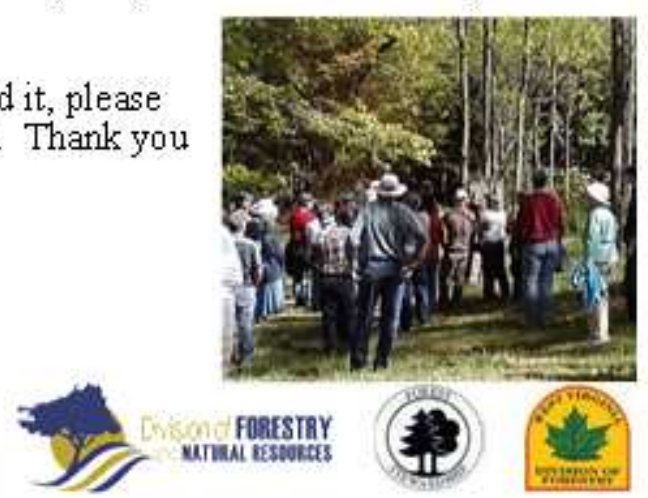


\section{APPENDIX F. Reminder Letter}

February 2014

Dear West Virginia Woodland Owner:

About a month ago we mailed you a questionnaire that is part of a West Virginia University research project seeking information about your experience as a West Virginia woodland owner. According to our records, you have not yet returned the survey.

We are writing again because your participation in this survey is important to get accurate results. It is by hearing from a majority that we get a representative view of the actions and attitudes of West Virginia woodland owners. Please consider contributing your experience and knowledge to this research effort.

Again, your participation in this survey is voluntary and you can quit at any time without penalty. You do not have to answer all of the questions, but any information you provide will contribute to the project's success. You must be over 18 years of age to participate. If you do not wish to participate, please let us know by returning the enclosed questionnaire, blank or with a note, in the prepaid envelope provided.

Information you provide is confidential and your name and answers will never be connected to your answers in any way. West Virginia University Institutional Review Board's acknowledgment of this study is on file.

If you have any further questions, please feel free to contact us. It is with your generous help that this research can be successful.

Sincerely,

Ana Maria Erazo, Coordinator

Landscape Forest Stewardship Project

Email: anamariaerazohn@yahoo.com
Dr. Dave McGill, Principal Investigator

Professor/Extension Specialist

Phone: 304-293-5930 


\section{APPENDIX G. List of conservation organizations identified by postcard respondents}

\begin{tabular}{|c|c|c|}
\hline NAME & $\mathbf{N}$ & County initial \\
\hline A.S.S Charlestown WV Jefferson Co & 1 & $\mathrm{~J}$ \\
\hline Apalachian Trail Club & 1 & $\mathrm{~J}$ \\
\hline Auduborn Society (Potomac) & 2 & $\mathrm{~J}, \mathrm{M}$ \\
\hline Beech Fork State Park & 1 & $\mathrm{C}$ \\
\hline Berkeley County Farmland Protection Board, & 3 & $\mathrm{~B}, \mathrm{~B}, \mathrm{~B}$ \\
\hline Div of Forestry Inwood WV & 1 & $\mathrm{~B}$ \\
\hline do not know & 2 & ML,C \\
\hline Eastern panhandle Conservation District & 1 & $\mathrm{~B}$ \\
\hline Extension Service WVU & 2 & $\mathrm{~J}$ \\
\hline Farm Bureau Master Gardener & 1 & $\mathrm{~B}$ \\
\hline Isaac Walton League & 1 & $\mathrm{R}$ \\
\hline Jefferson County Economic Development Authority & 1 & $\mathrm{~J}$ \\
\hline Jefferson County Farmland Protection Board & 1 & $\mathrm{~J}$ \\
\hline Lake Forest Estates Home Owners Association & 1 & $\mathrm{~J}$ \\
\hline Land trust of Eastern Panhandle, & 3 & $\mathrm{~J}, \mathrm{~B}, \mathrm{~B}$ \\
\hline Land Trust of Virginia (LTV) & 2 & $\mathrm{~J}, \mathrm{~J}$ \\
\hline Loudown Wildlife, & 1 & M \\
\hline Milton Office WV Div of Forestry & 1 & $\mathrm{C}$ \\
\hline MSU Extension Services & 1 & M \\
\hline N/A & 2 & $\mathrm{ML}, \mathrm{C}$ \\
\hline $\begin{array}{l}\text { Names(Herb Pettigor, Mike Sieber. Scott Mc } \\
\text { Daniel) }\end{array}$ & 3 & $\mathrm{~B}, \mathrm{~J}, \mathrm{M}$ \\
\hline Natural Resources and Conservation Service & 3 & $\mathrm{~J}, \mathrm{~J}, \mathrm{ML}$ \\
\hline Nature Conservancy & 1 & M \\
\hline None & 9 & $\mathrm{M}, \mathrm{M}, \mathrm{ML}, \mathrm{ML}, \mathrm{R}, \mathrm{J}, \mathrm{C}, \mathrm{C}, \mathrm{C}$ \\
\hline Northern Panhandle Conservation Distric & 2 & ML \\
\hline Not sure & 1 & $\mathrm{M}$ \\
\hline Ohio Valley Environmental Coalition (OVEC) & 1 & $\mathrm{C}$ \\
\hline Opequon Creek Project team & 1 & $\mathrm{~B}$ \\
\hline Piedmont Environmental Council (PEC) & 1 & $\mathrm{~J}$ \\
\hline Ruffed grouse Society & 1 & $\mathrm{C}$ \\
\hline SOIL CONSERVATION DISTRICTS & 1 & M \\
\hline Sustainable Solutions,LLC & 1 & $\mathrm{~J}$ \\
\hline Trout Unlimited, & 1 & $\mathrm{R}$ \\
\hline USDA & 2 & ML, M \\
\hline Virginia Outdoors Foundation (VOF) & 1 & $\mathrm{~J}$ \\
\hline West Virginia Chesapeake Bay Program, & 1 & $\mathrm{~B}$ \\
\hline WV Environmental Council & 1 & $\mathrm{C}$ \\
\hline WVU Div Of Forestry & 1 & M \\
\hline
\end{tabular}

